\title{
Evaluating mitigation translocations for better biodiversity outcomes
}

Sydney Michelle Dean

A thesis submitted to Victoria University of Wellington in partial fulfilment of the requirements for the degree of Master of Science in Ecology and Biodiversity

2021

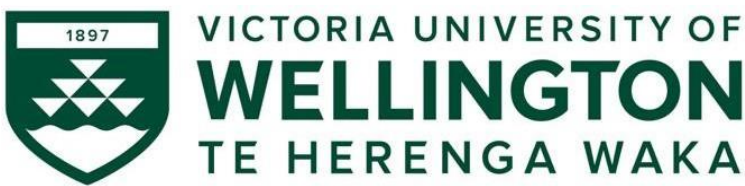





\section{Abstract}

The expansion of urban areas and associated loss of natural areas due to development are greatly contributing to global biodiversity loss. Furthermore, development produces direct harm to wildlife and their habitat. In New Zealand, lizards and their habitat are legally protected and damage due to development of a natural area must be avoided or mitigated whenever possible. Mitigation translocations, the intentional relocation of individuals from the site to be developed to a receptor site, have become commonly used to meet legal obligations; however, mitigation translocations do not guarantee survival of individuals or population success at the receptor site. I aimed to evaluate the success of a mitigation translocation case study, proactively plan receptor sites for a mitigation translocation, and develop a framework for selecting and preparing receptor sites to provide better mitigation translocation outcomes, particularly for herpetofauna. I evaluated the short-term success of a mitigation translocation case study using results from post-release monitoring at receptor sites. This is one of the first studies to provide multiple post-release monitoring sessions and detail recapture rates and body condition changes of lizards at receptor sites with and without resident populations following mitigation translocation. I expanded upon commonly used receptor site selection criteria and translocation data management systems by proactively studying and preparing receptor sites in regional parks, including conducting pilot surveys to evaluate resident populations. Recapture rates were similar between receptor sites (9\% and 11.8\%) and the limited number of recaptured individuals showed an increase in body condition from the time of salvage to intervals of one- 
and two-years post-release. Presence of residents was not found to have an effect on recapture rates or body condition changes. Implementation of enhanced site selection criteria resulted in approval of six sites within three protected areas for future mitigation translocations. These sites had low numbers of resident lizards present, if at all. A geodatabase was developed to store results from receptor site evaluations before and after translocation. Together, the improved criteria and geodatabase fit into a framework for selecting and preparing receptor sites to improve outcomes of mitigation translocations of herpetofauna. The framework produced has potential to be used at a national level, in collaboration with ecologists, iwi, and community groups, and for a variety of species. Mitigation translocations should be reevaluated as the go-to method to mitigate damage to lizards due to development; however, if they must continue, it is essential that best practices are used, and results are published so that outcomes can improve for biodiversity. 


\section{Acknowledgements}

I wish to thank Nicky Nelson and Chris Woolley most sincerely for seeing my potential and encouraging me to pursue this degree, even when it happened at a painstaking pace. Thank you for turning around proofreading with lightning speed when my own timelines ran away from me and for always letting me have a good, solid cry when life was overwhelming. We accomplished so many wonderful things together during a pandemic and I will never cease to be proud of this team and what we produced with your help and patience. I would also like to thank the examiners of this thesis, who helped it become more robust and a better contribution to the study of mitigation translocations of herpetofauna.

This work would not have been possible without the support of multiple iwi, organizations and research groups who gave me permission to work in the Wellington region and shared their valuable expertise in herpetology, conservation, and governmental policy. Particularly, the Centre for Biodiversity and Restoration Ecology, Michele Frank and Daniela Biaggio (Wellington City Council), Richard Romijn, Owen Spearpoint, and Phillipa Crisp (Greater Wellington Regional Council), Angus Holmes-Muir, and Lyn Adams (Department of Conservation). I wish to specifically thank the rangers in Queen Elizabeth and Belmont Parks who contributed tremendously to site visits and kept me safe during long days of remote field work, in particular Anna Porter, Brendan Bulliff, Jeremy Patterson, and Wayne Burress. Whareroa Guardians and Friends of QEP will forever have my thanks, for sharing your data, your assistance with digging many pitfall traps into the ground and continuing to check them, and your passion for the conservation of native lizards. Particular thanks are to Glenda Robb, Paul Callister, Theo Barsanti, and Bruce Bulmer who were always happy to give us a lift 
through the park! I will happily live the rest of my life without ever digging a pitfall trap into a rocky, coastal site again. That being said, I have dozens of people to thank for helping me deploy pitfalls in the hot sun and check hundreds of lizard traps, but particularly wish to thank Doug Rands (officially promoted to Pitfall Digging Supervisor), Daniel Anderson, Mikaela Karlsson, and Phoebe McClean My gratitude to my lab group and colleagues, who listen to me ramble and then read my incoherent thoughts on paper: LinLin Liu, Ox Lennon, Sarah Herbert, Brittany Florence-Bennett, Sarah Lamar, Liam McAuliffe, Florence Kelly, Michelle Goh, Shannon Bentley, Cherie Balls, and countless honorary members. I also wish to thank Sue Keall and Mel Dohner for assistance with field gear and patiently working with last-minute changes in the early morning hours.

I have three families to thank: firstly, my patchwork family in New Zealand. Your bad jokes, kind words, and generous hearty meals kept me going these last two years when home felt much further away than normal. Special thanks to Sarah Herbert and Alex Horvat who shared their home with me for better or for worse, the Pancake Squad who were the first people to make me feel home in New Zealand and Elisia, Kasey Mollison and Chris Sterley for absolutely wild adventures, and Simon Harnden who is the calm amidst the chaos that I bring unto myself. Thank you to the family with whom I share my name: my mother and grandmother who have, after two long-term international trips within 5 years, adjusted very well to my adventurous lifestyle. Being the first grandchild can be a blessing and a curse and being the first generation to graduate college, let alone with a postgraduate degree, can be daunting but was made possible by your absolute faith in me since day one. My last thanks are to my ever-supportive, ever-sassy soul sister, Ariel Jackson, and the embodiment of my true self, Fariss Hogue-Ziao. Thank you for answering every call, being gentle when need be and stern when I was stubborn. 


\section{Table of Contents}

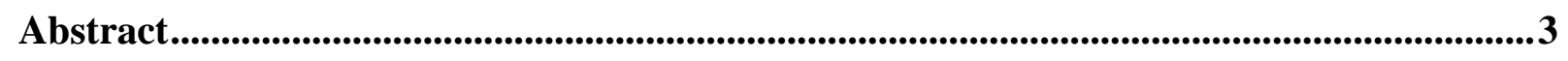

Acknowledgements ....................................................................................................................5

Chapter 1 .................................................................................................................10

Mitigation translocations of herpetofauna and their receptor sites ........................................... 10

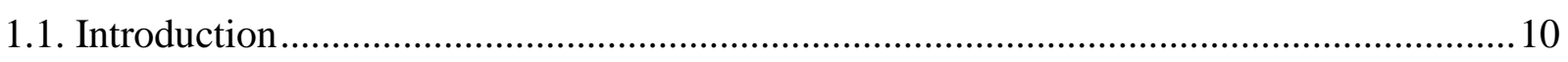

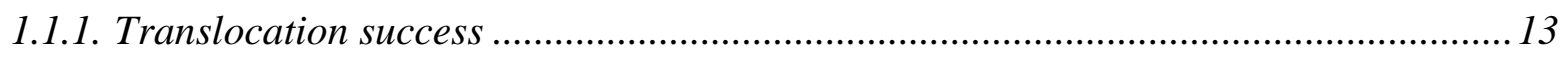

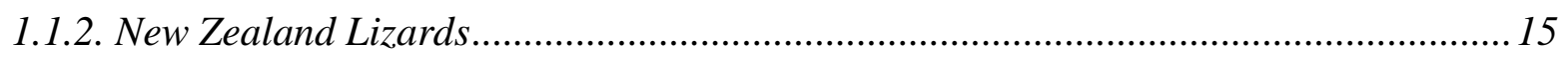

1.1.3. New Zealand Mitigation Translocations of Herpetofauna........................................... 18

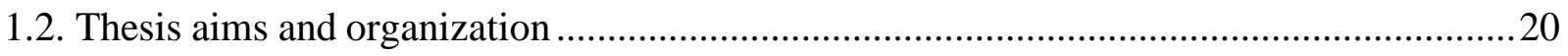

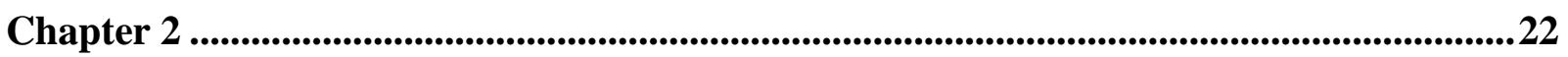

Short-term success criteria for a mitigation translocation........................................................22

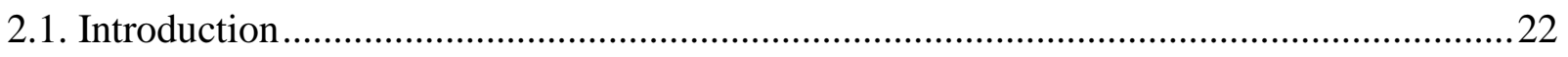

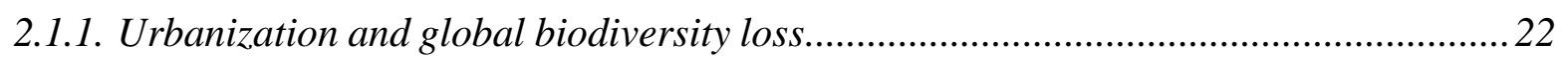

2.1.2. New Zealand mitigation translocations of herpetofauna ………………………….......23

2.1.3. Concerns with current $N Z$ mitigation translocation practices ....................................25

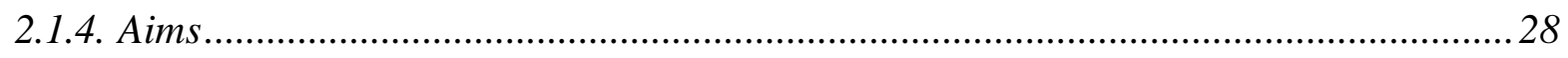

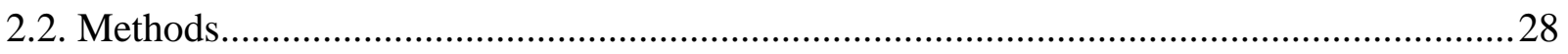

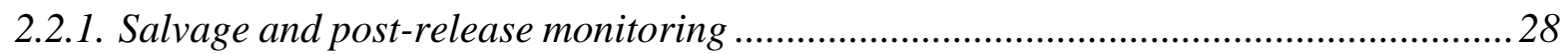

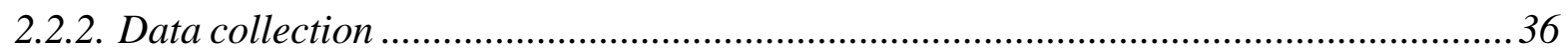

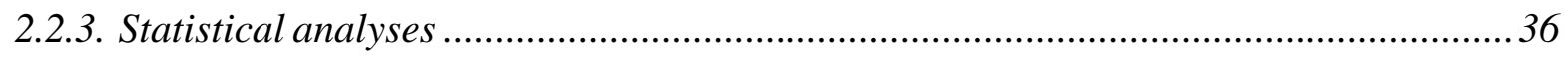

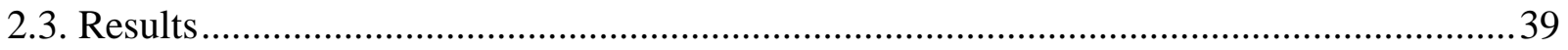

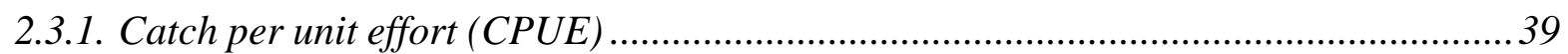

2.3.2. Recapture rates........................................................................................... 43

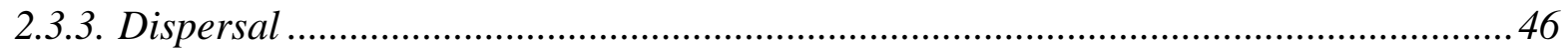

2.3.4. Body condition changes..................................................................................... 46

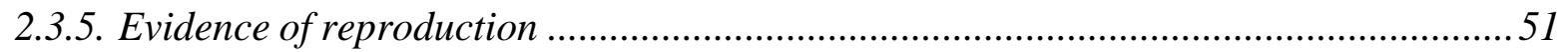

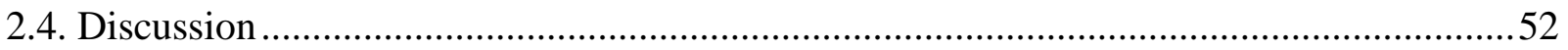

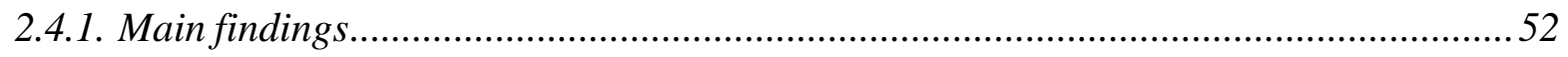




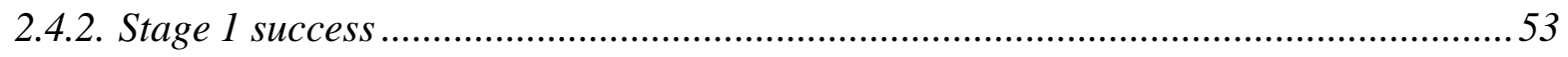

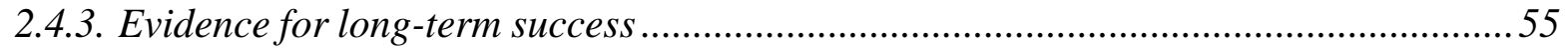

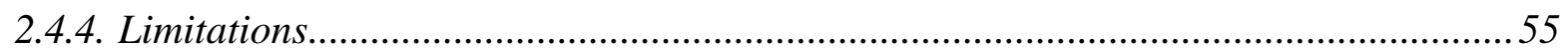

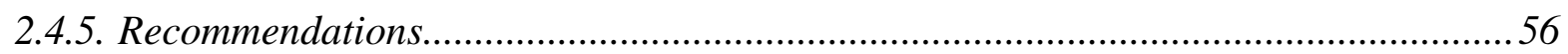

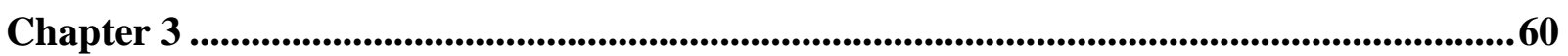

Receptor site preparedness for mitigation translocations of lizards..................................... 60

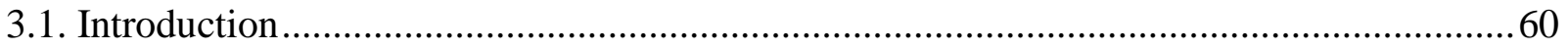

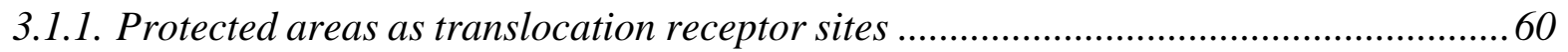

3.1.2. Mitigation translocations of New Zealand herpetofauna ............................................ 61

3.1.3. Greater Wellington Regional Council Research Project..............................................64

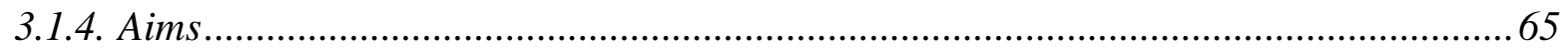

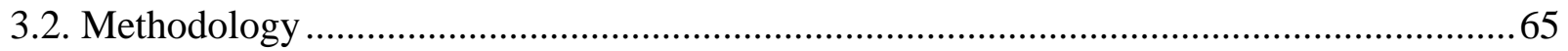

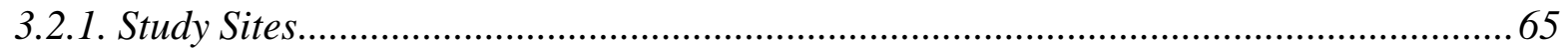

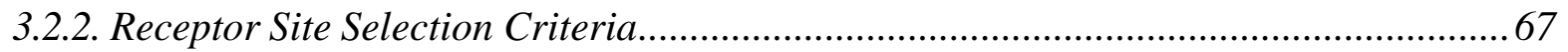

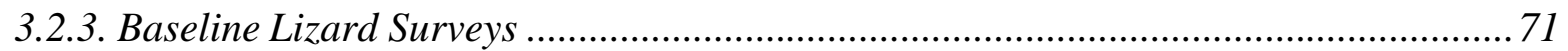

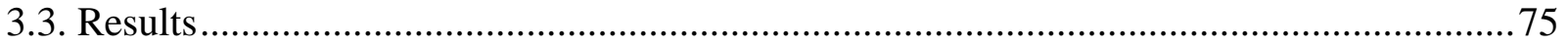

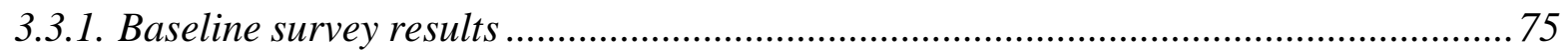

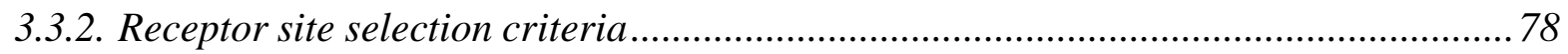

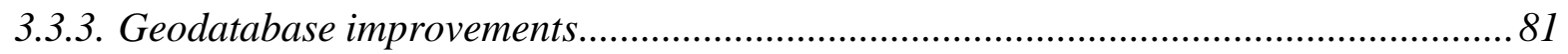

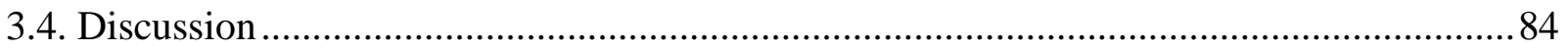

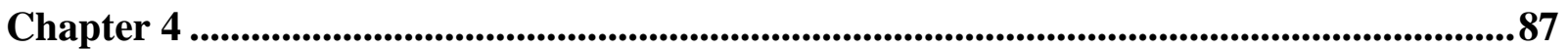

Selection and preparation of mitigation translocation receptor sites ....................................88

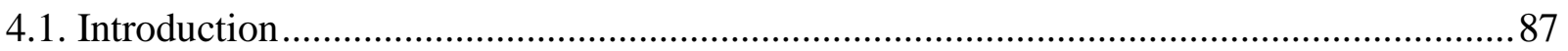

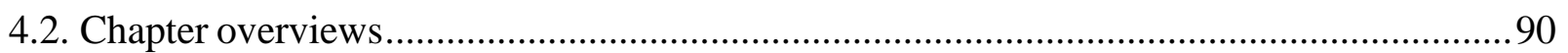

4.2.1. Chapter two: Short-term success criteria for a mitigation translocation.................... 90

4.2.2. Chapter three: Receptor site preparedness for mitigation translocations of lizards ......92

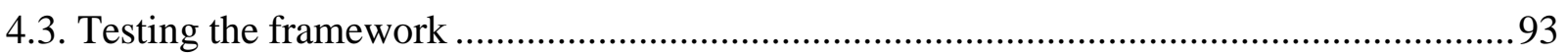

4.3.1. What aspects of the framework need further testing and expansion? .........................96

4.3.2. How can this framework be applied more widely? ..................................................97 


\section{Chapter 1}

\section{Mitigation translocations of herpetofauna and their receptor sites}

\subsection{Introduction}

Urbanization is regarded as one of the top contributors to global biodiversity loss, resulting in significant decline for a large number of species (Bongaarts, 2019). A dramatic increase in the human population (doubling in the last 50 years; Roser et al., 2013) increases pressure on what are already heavily populated urban areas. Urban areas currently account for approximately $3 \%$ of global land cover and are expected to triple in the next decade to accommodate the growing population (Potere \& Schneider, 2007; Grimm et al., 2008). As urban boundaries expand, indigenous land covers which provide habitat for wildlife are replaced by buildings, roadways, farmlands and public access areas (Decker \& Chase, 1997). This results in the loss and 
fragmentation of habitat leading to the endangerment of and loss of species (McKinney, 2006; Gallego- Carmona et al., 2016; Newmark et al., 2017; Markle et al., 2018). Destruction of habitat eliminates the possibility for wildlife to safely remain in their original areas during construction and there are many options for responding to development applications which propose to endanger native wildlife. These include, declining applications for development (Department of Conservation, 2019), negotiating environmental and/or biological offsets (Brown et al., 2013; Moreno-Mateos et al., 2015; Le Coent et al., 2017; Maseyk et al., 2018), or mitigating direct harm by translocating wildlife from the development site (a type of mitigation translocation, Germano et al. 2015). The mitigation response chosen depends on case-by-case negotiations between developers, territorial authorities (councils or landowners of the site to be developed), contracted ecologists or advisors, and governing bodies which enforce protection of wildlife or natural areas (Anderson et al., 2012; Pérez et al., 2012; Sarah Herbert pers. comm.). Factors which may influence the response option selected include legal obligations or protections (e.g. threat status classification), ecological and biological considerations for the species to be impacted, and logistical restrictions such as timelines and financial constraints (Brown et al. 2013; Germano et al., 2015; Lennon, 2019; Nash et al., 2020).

Mitigation translocations are the intentional movement of organisms from a site set for development to another location to mitigate damages caused to organisms (IUCN/ SSC, 2013), and are quickly becoming the most common 'solution' to mitigate wildlife-development conflicts (Miller et al., 2014; Germano et al., 2015). The International Union for Conservation of Nature (IUCN) recommends mitigation translocations follow the same translocation guidelines and standards as conservation translocations (IUCN/SSC, 2013; Batson et al., 2015); however, recent studies report inconsistencies in the application of these standards (Germano et al., 2015; Sullivan et al., 2015; Bradley et al., 2020), particularly for herpetofauna (Edgar et 
al., 2005; Harper et al., 2018; Nash \& Griffiths, 2018; Nash et al., 2020). Furthermore, mitigation translocations are the most common translocation type to report inconclusive or failure results and do not often prioritize establishment of a viable population (Germano \& Bishop, 2009; Germano et al., 2015), the previous determinant of a successful translocation (Griffith et al., 1989; Dodd \& Seigel, 1991).

While conservation and research-driven translocations generally focus on the survival of individual animals (and overall net conservation benefit) and use "best practices" as recommended by the IUCN, success rates vary depending on species and translocation methodology (Griffith et al., 1989; Fischer \& Lindenmayer, 2000; Germano \& Bishop, 2009; Ewen et al., 2014). Best practices include identification of and control for the agent of decline, preparation of the receptor site, long-term post-release monitoring and supplementation to habitat and the population as needed to encourage establishment (Batson et al., 2015; IUCN/SSC, 2013). In contrast to conservation translocations, mitigation translocations may occur in order to comply with country-specific wildlife protection legislation (WildlifeAct, 1953 (NZ); Endangered Species Act of 1973 (USA); Wildlife \& Countryside Act, 1981 (UK); Resource Management Act, 1991 (NZ); Animal Welfare Act, 1992 (AUS); Conservation of Habitats and Species Regulations, 2010 (UK); IUCN/SSC, 2013; Nature Conservation Act, 2014 (AUS)), and therefore may not use "best practice" protocols. This is concerning given their track record of inconclusive or failed results (Edgar et al., 2005; Germano et al., 2015; Sullivan et al., 2015; Devan-Song et al., 2016; Lennon, 2019; Bradley et al., 2020). Researchers are continuing to question the protocols used in mitigation translocation scenarios and are challenging whether they should occur, since they are often proposed as go-to methodology when wildlife stands in the way of development (Dodd \& Seigel, 1991; Germano et al., 2015; Sullivan et al.,2015; Bradley et al., 2020; Nash et al., 2020). 


\subsubsection{Translocation success}

Determinants of translocation success have been widely debated and requested by translocation reviewers for almost 3 decades (Griffith et al., 1989; Dodd \& Seigel, 1991; Fischer \& Lindenmayer, 2000; Germano \& Bishop, 2009) and are still not clarified today, although progress has been made to identify objective and achievable goals using re-introduction biology literature (Armstrong \& Seddon, 2008; Pérez et al., 2012; Miller et al., 2014; Bradley et al., 2020). These include defining objectives with timeframes to determine project success, collection of baseline data, appropriate release circumstances covering aspects of species biology and behaviour, site preparedness, and most importantly management of factors linked to population declines, follow-up monitoring, and publication of results regardless of outcome (Seigel \& Dodd, 2002; Germano \& Bishop, 2009; Moseby et al., 2011; Miller et al., 2014; Germano et al., 2015; Romijn \& Hartley, 2016).

There is a growing body of research evaluating how to determine the success of translocations for herpetofauna (Dodd \& Seigel, 1991; Fitzgerald et al., 2015; McCoy et al., 2014; Miller et al., 2014; Romijn \& Hartley, 2016). Early reviews of wildlife translocations report an imbalance in success rates based on taxonomic group - success rates of repatriations and translocations of mammals and birds was twice as high as that of herpetofauna (44\% and 19\%, respectively (Griffith et al., 1989; Dodd \& Seigel, 1991)). However, Germano \& Bishop (2009) reviewed the global translocations of herpetofauna from 1991 - 2006 using short-term markers of success, such as, evidence of recruitment and evidence of founder (translocated individuals) survival, or an increased population size documented in long-term monitoring. With these criteria, $42 \%$ of reviewed herpetofauna translocations were classified as successful. The study separately evaluated translocations motivated by human-wildlife conflict ( $16 \%$ of reviewed reptile translocations, although this group included translocations in response to development and nuisance animal conflict) and reported these had higher failure rates ( 
$62.5 \%)$ than conservation or research-motivated translocations; ( 15\%, Germano \& Bishop, 2009).

Regardless of the motivating factor, measuring success of reintroductions or translocations is a non-trivial undertaking. Long-term goals are generally the eventual development of a viable self-sustaining population, whereas short-term success might be measured by observation of new recruitment within the translocated group and population growth (Griffith et al., 1989; Dodd \& Seigel, 1991; Seddon et al., 2007; Germano \& Bishop, 2009; Germano et al. 2015). Long-term goals can be difficult to reach within 5 - 10 years for many species, particularly for herpetofauna which might reproduce slowly (Dodd \& Seigel, 1991; Germano et al. 2015; Sullivan et al., 2015). Many translocations only receive shortterm monitoring ( $<5$ years) post-release, if any, making it difficult to classify them as successful (even in the short-term; Dodd \& Seigel, 1991; Germano et al., 2015; Sullivan et al., 2015), particularly for long-lived species with low reproductive output such as some New Zealand lizards (Miller et al., 2014; Cree \& Hare, 2016; Romijn \& Hartley, 2016). Miller et al. (2014) modified traditional success criteria into four stages to assess translocation outcomes based on the time since release. Romijn \& Hartley (2016) expanded on these stages by applying timeframes based on common lizard life histories. Their application was relevant for evaluating New Zealand lizards; the four stages were: 1. survival and growth of founders ( $0-4$ years post-translocation), 2. evidence of reproduction (5-9 years), 3. population growth (10+ years), and 4. viable population (15+ years). These criteria have begun to be used as tools to assess success of lizard populations in New Zealand in translocation research projects (Miller et al., 2014; Romijn \& Hartley, 2016; Lennon, 2019) and habitat use studies (Herbert, 2020).

In reviews of mitigation translocations, the projects are generally evaluated against criteria such as those listed above; however, mitigation translocations often have legal 
obligations instead of or alongside conservation goals (Germano et al., 2015). This means, to assess success of a mitigation translocation, the objectives and timeline for evaluation must be detailed, including legal obligations such as removal of wildlife, provision of enhancement or supplementary aid at receptor sites, or offsets which benefit other conservation efforts outside of the translocation (Brown et al. 2013, 2014; Maseyk et al., 2018). While some studies show that mitigation translocations appear to meet legal obligations (Lennon, 2019), this does not mean they meet conservation goals or provide net conservation benefits, and in fact may cause net biodiversity or habitat loss (Moreno-Mateos et al., 2015; Le Coent et al., 2017).

\subsubsection{New Zealand Lizards}

The New Zealand archipelago hosts one of the highest diversities of lizards adapted to cool temperate environments on the globe (Towns et al., 2016). There are now 100+ taxa in the Scincidae (Daugherty et al., 1994) and Diplodactylidae families (Hitchmough et al., 2016a). Lizards are a dominant fauna on the terrestrial landscape, with some species occupying wide ranges (e.g. coastal habitats, alpine and sub-alpine areas, native forests and bush; Chapple \& Hitchmough, 2016; Towns et al., 2016). New Zealand lizards have slow life histories with most reaching sexual maturity by $4-7$ years of age, and low reproductive output ( $2-3$ offspring/ breeding period with some only producing offspring every second year; Cree \& Hare, 2016). These traits make it difficult to determine population viability and conservation status with short-term monitoring.

Currently, $87 \%$ of the 106 described taxa are listed by the New Zealand Threat Classification System as "Threatened" or "At Risk", with many taxa still listed as "Data Deficient" (Hitchmough et al., 2016a). Main threats to New Zealand lizards are predation from introduced mammals and habitat loss (Knox et al., 2014; Hitchmough et al. 2016). Lizards were 
greatly impacted by the arrival of human settlers, nearly 700 years ago, experiencing predation from novel mammalian predators and habitat loss due to land use changes (native forest and bush being cleared for agricultural purposes, Towns and Daugherty 1994; Wilmshurst et al., 2008).

New Zealand fauna evolved on the archipelago for millions of years without the presence of mammalian predators. A suite of introduced mammals such as rats (kiore, Rattus exulans, $R$. norvegicus, and $R$. rattus), mustelids (stoats (Mustela erminea), ferrets (M. furo), and weasels (M. nivalis), mice (Mus musculus), along with some domesticated animals (e.g. dogs (Canis familiaris), cats (Felis catus)) prey on native reptiles (Hoare et al., 2007; Salo et al., 2007; Wilson et al., 2017). Predator control has increased in the country since studies reported a positive relationship between the eradication of introduced predators on offshore islands and improved survivability and reproduction of native species (Whitaker, 1973; Towns, 1991; Towns, 1995; Monks et al., 2014; Parkes et al., 2014; Jones et al., 2016). Predator control of introduced mammalian predators (henceforth referred to as simply "predator control") currently involves distribution of poison baits and/or trapping; results of predator control studies inspired the development of predator-proof fences for mainland sanctuaries, specifically designed to keep areas free of mammalian predators (Burns et al., 2012; Nelson et al., 2016; Pech \& Maitland, 2016; Innes et al., 2019). Eradication of introduced predators is an intensive process, particularly on mainland areas, and requires longterm monitoring to ensure areas remain free from mammalian predators. When eradication is not possible, long-term maintenance of control techniques is required (Reardon et al., 2012; Russell et al., 2015; Glen et al., 2019). Predator Free New Zealand (2050) is a government initiative to eradicate mammals with the most impact on native flora and fauna (as identified by the Department of Conservation (DOC) and relevant studies) from the entirety of New Zealand by 2050, with milestones set until then including regional management and eradication 
plans (Department of Conservation, 2020b). Target mammalian predators include mustelids, rats (Rattus exulans are a taonga for some iwi - requiring further discussion for eradication), and brush tailed possums (Trichosurus vulpecula; Owens, 2017; Department of Conservation, 2020b). The program does not target mice, European hedgehogs (Erinaceus europaeus), and feral cats (Linklater \& Steer, 2018; Peltzer et al., 2019), which have also been reported preying on lizards (Gillies \& Clout, 2003; Spitzen - van der Sluijs et al., 2009; Rouco et al., 2017); some non-target mammals may experience competitive or meso-predator release when target mammals are removed (Spitzen - van der Sluijs et al., 2009; Goldwater et al., 2012; Broome et al., 2017; Wilson et al., 2018).

Although the primary loss to habitat in New Zealand occurred when humans arrived as a result of burning and clearing for agricultural practices (Towns \& Daugherty, 1994; Wilmshurst et al., 2008; Singers \& Rogers, 2014), expansion of urban cores and development of natural areas continues to result in habitat loss for wildlife and overall biodiversity loss. We have little information on lizards in urban areas compared to protected habitat on offshore islands (Woolley et al., 2019). However, lizards are often encountered when development occurs in cities (Wildland Consultants, Ltd., 2019c).

All native New Zealand lizards and their habitat are protected by three laws (Miskelly, 2014). The Wildlife Act 1953 protects terrestrial vertebrates from being handled or disturbed without a permit. The Conservation Act 1987 conserves indigenous biodiversity, establishing the Department of Conservation and empowering DOC to intervene for the protection of biodiversity, including acting as the Wildlife Authority for permits under the Wildlife Act. Lastly, the Resource Management Act (1991; RMA) provides protection of lizard habitat and requires that development plans conduct biological surveys to assess the scale of damage to the environment and biodiversity. Furthermore, if development plans score higher than "minor impact", a resource consent permit and a plan to remedy, mitigate, or offset damages to 
wildlife and the environment is required under the RMA (Anderson et al. 2012). The RMA is enacted by territorial authorities (city councils under regional council guidance; Resource Management Act, 1991). The legal obligation to protect lizards and their habitat while still meeting the needs of urban expansion has led to the development of lizard management plans and use of mitigation translocations in New Zealand (Sherley et al., 2010; Anderson et al., 2012; Germano et al., 2015).

\subsubsection{New Zealand Mitigation Translocations of Herpetofauna}

New Zealand is well known for pioneering reintroduction biology and conservation translocations (Department of Conservation, 1999; Seddon et al., 2007; Romijn \& Hartley, 2016). Before 2003, conservation- and research-driven translocations of herpetofauna were the only reported translocations since the DOC translocation database was developed in the 1980's (Romijn \& Hartley, 2016). These were largely to conserve or re-introduce endangered lizard and reptile populations (tuatara, Sphenodon spp.) and involved transferring mainland populations to offshore islands following successful predator eradication (Nelson et al., 2002; Cromarty \& Alderson, 2013; Romijn \& Hartley 2016). However, the development and enforcement of the RMA has resulted in mitigation translocations becomingone of the most common types of translocation in New Zealand, occurring as frequently as conservation translocations from 2003 - 2013 (Romijn \& Hartley 2016).

Romijn \& Hartley (2016) reviewed 28 mitigation translocations of herpetofauna in New Zealand. A majority of reviewed mitigation translocations did not report post-translocation monitoring data (68\%) and if post-release monitoring occurred it was for less than 4 years with only one occurrence of post-release monitoring 5 - 9 years post-release (Romijn \& Hartley, 2016). These results follow trends observed in recent mitigation translocation

reviews (such as Miller et al., 2014; Germano et al., 2015; Sullivan et al., 2015). Lennon 
(2019) accessed nine mitigation translocations and revisited them to assess short-term success $5-10+$ years after release in lieu of this earlier recognised lack of monitoring or data reporting. They found that several of the sites could not be assessed against short-term success criteria due to a lack of permanent identifiers used on founders, lack of monitoring $0-4$ years post-release (33\%), or lack of pre-release monitoring for resident individuals which confound capture records in subsequent monitoring efforts (22\%, at varying levels of effort for the other $78 \%$ ). Only two of the nine translocations showed evidence of reproduction - not necessarily meeting a standard for Stage 2 success but providing evidence to support reproduction may be occurring at those sites. These publications and the global reviews of mitigation translocations which came before them provide evidence for caution around the use of mitigation translocations, and the need for development of better practice and/or legal requirements when conducting mitigation translocations to ensure their measurable success. In particular, these studies emphasize the need for use of permanent lizard identification tools, lizard monitoring and marking at receptor sites, reporting of salvage and post-release data, receptor site preparation including habitat evaluation and enhancement as needed, predator control and monitoring pre- and post-release, and standardized planning and framework to apply best practices. Recent studies (in New Zealand and globally) continue to experiment with techniques to improve biodiversity outcomes of mitigation translocations (for herpetofauna, particularly). These include, habitat enhancement at receptor sites (Fitzgerald et al., 2015; Nafus et al., 2017; Harper et al., 2018; Lennon, 2019), conducting 'soft -releases' (DeGregorio et al., 2020; Flynn-Plummer \& Monks, 2021), evaluating post-release dispersal (Knox \& Monks, 2014; Angeli et al., 2018; Nash \& Griffiths, 2018), continuing to evaluate determinants of success (Miller et al., 2014; Bradley et al., 2020) and publishing results (even of failed translocations, such as Nash et al., 2020).

Mitigation translocations are currently reactive events and territorial authorities find 
themselves in a position of being approached under tight timeframes for access to their sites to provide opportunities for rehoming lizards resulting from local developments. In New Zealand, there is an appetite to implement best practices as outlined by the IUCN and DOC (Department of Conservation Technical Advisory Group, 2018; 2019) in mitigation translocations, particularly for a more proactive approach for the selection and preparation of receptor sites. The situation is made more complex because little is known about diversity and abundance of lizards in urban areas. The demand for mitigation translocations to provide better biodiversity outcomes has been well documented in literature and unless the key concerns can be identified and resolved, they should be strongly reconsidered as an option to mitigate damage to wildlife.

\subsection{Thesis aims and organization}

I aimed to evaluate the success of a mitigation translocation, to proactively plan for a mitigation translocation, and to use these learnings to develop a framework for conducting mitigation translocations that would bring more rigor to the process and ultimately better outcomes for the translocations.

In Chapter 2 I evaluate short-term success of a mitigation translocation, including the recapture of translocated individuals and changes in their body conditions. I address the impact of a "resident" population on translocated lizards.

In Chapter 3 I develop a set of criteria to assist territorial authorities to proactively select and prepare receptor sites for future mitigation translocations, including researching local lizard populations, preparing and testing a geodatabase for receptor sites, and recommending a framework for selecting and preparing receptor sites for mitigation translocations of lizards.

Chapter 4 is a discussion chapter where I test the framework from Chapter 3 using the 
translocation followed in Chapter 2. I make recommendations and outline future opportunities for the expansion and application of this framework.

Data chapters of this thesis are written for journal publication (Chapter 2) or for management recommendation documents for governmental use (Chapter 3). As such, there is some repetition between chapters, particularly in Introduction sections. This thesis is one of the first to follow a mitigation translocation of native skinks and report on their survival and growth over two years post-release. Results and observations from this study inform the criteria developed for selection of mitigation translocation receptor sites for native skinks. These criteria are prepared and tested as part of a larger research project being conducted by Greater Wellington Regional Council, in an effort to apply "best-practice" protocols to mitigation translocations of lizards and assess their usefulness in mitigating human impacts on urban lizard populations.

This project was conducted under Victoria University of Wellington Animal Ethics Committee approval (AEC27041), Department of Conservation Wildlife and Conservation Act permit (Wildlife Act Authority - 50568-FAU), and Wellington City Council and Greater Wellington Regional Council permits for site access and alteration (low impact collecting permit). Iwi consultations included Ngāti Toa Rangatira, Te Atiawa ki Whakarongotai, and Taranaki Whānui ki Te Upoko o Te Ika. 


\section{Chapter 2}

\section{Short-term success criteria for a mitigation translocation}

\subsection{Introduction}

\subsubsection{Urbanization and global biodiversity loss}

The urbanization of the human population has driven a dramatic expansion in the land cover occupied by cities (estimated to have tripled in the last decade; Roser et al., 2013). Increasingly, urbanization is being recognised as one of the leading causes of global biodiversity decline (Decker \& Chase, 1997; Czech et al., 2000; McKinney, 2006; Bongaarts, 2019). In most countries, wildlife is protected by law and development sites must have biological assessments prior to land use change (such as: Endangered Species Act of 1973 (USA), Wildlife \& Countryside Act 1981 (UK), Animal Welfare Act 1992 (AUS), Conservation of Habitats and Species Regulations 2010 (UK), Nature Conservation Act 2014 (AUS)). However, legal 
obligation and actions used to mitigate the impact of development onwildlife vary considerably among countries (e.g. financial compensation for alternative conservation projects or development plans altered to exclude habitat; Brown et al., 2013; Le Coent et al., 2017; Maseyk et al., 2018). One common solution is a mitigation translocation, the relocation of individuals from the site where development will take place to a receptor site (Germano et al., 2015). While mitigation translocations rescue individuals from immediate danger, they do not often result in positive conservation outcomes and their usefulness as a mitigation method has been questioned (Germano et al., 2015; Sullivan et al., 2015; Lennon, 2019). Mitigation translocations of lizards were first documented in New Zealand in 2003 (Sherley et al., 2010) and within 10 years were occurring almost as frequently as conservation translocations (23 mitigation and 24 conservation translocations reported from 2003 - 2013; Romijn \& Hartley, 2016).

\subsubsection{New Zealand mitigation translocations of herpetofauna}

Currently, $87 \%$ of $100+$ known lizard taxa are listed as 'Endangered' or 'At Risk' using the New Zealand Threat Classification System (Hitchmough et al., 2016a). Lizards are vulnerable to introduced mammalian predators (Whitaker, 1973; Towns, 1991; Whitlow et al., 2003; Wedding, 2007) and many species are likely affected by increasing urbanization (Towns \& Daugherty, 1994), particularly when their lives and their habitat are directly endangered due to urban development. A recent study of New Zealand lizards in cities reports that $38 \%$ of lizard species have historic home ranges that include cities, of which only $40 \%$ are still found in cities (Woolley et al., 2019). Four Oligosoma species were recorded as present infour cities (O. polychroma, $O$. aff. polychroma clade 5, O. aeneum, and $O$. ornatum), but trapping techniques likely missed the presence of other lizards which may have historical ranges in cities but were not captured using terrestrial monitoring techniques (for example, arboreal geckos). Further research on lizards in urban areas, particularly cities, will inform urban conservation 
decisions and is a requirement in many national, regional, and city council biodiversity strategies (Auckland Council, 2012; Department of Conservation, 2020a; Hawke's Bay Regional Council, 2015; Otago Regional Council, 2018; Taranaki Regional Council, 2017).

New Zealand lizards are protected through three main laws: the Conservation Act (1987), the Resource Management Act (1991; RMA), and the Wildlife Authority Act (1953) (Miskelly, 2014). The acts work together to ensure the overall protection and conservation of lizards and their habitats. The Conservation Act (1987) protects indigenous biodiversity, empowering the Department of Conservation (DOC) to intervene and advocate for the conservation of native species; however, this law is not often invoked in mitigation translocations of species with a threat classification of "Not Threatened" (Department of Conservation Lizard Technical Advisory Group, 2019; Lennon, 2019) . If a species is recovered that is "Endangered" or "At Risk", translocation protocols must follow conservation translocation strategy (Wildlife Act, 1953; Department of Conservation Lizard Technical Advisory Group, 2018; 2019). The Resource Management Act (1991) mandates "sustainable resource management and the mitigation of adverse effects on the environment", protecting natural areas like indigenous lizard habitat and operating at a relatively large scale, focusing on population-level impacts. The RMA is enforced by territorial authorities (such as city councils under the guidance of regional councils) and developers must apply for a resource consent permit to alter land and negotiate impact mitigation strategies (Brown et al., 2013; Maseyk et al., 2018). Wildlife Act Authority (permit) is required from the Department of Conservation to handle or disturb lizards (Wildlife Act, 1953). These laws require the developer to work with territorial authorities, DOC, and ecological consultants to evaluate the best method to mitigate damage caused by the development on lizards and their habitat at the site (Department of Conservation Lizard Technical Advisory Group, 2019; Wildland Consultants, 2019c). Although lizards have a highlevel of protection which guards them from 
immediate danger at development sites (Wildlife Act, 1953; Resource Management Act, 1991; Towns et al., 2016), the outcomes of mitigation translocations often result in net biodiversity and habitat loss (Ewen et al., 2014; Germano et al., 2015; Sullivan et al., 2015; Lennon, 2019). Particularly, goals and obligations of mitigation translocations are to relocate lizards from development sites (Germano et al., 2015; Lennon, 2019) but stipulations over post-release monitoring and management vary among translocations; ultimately affecting outcomes (Brown et al., 2013; 2014; Ewen et al., 2014; Wildland Consultants, 2019c).

\subsubsection{Concerns with current NZ mitigation translocation practices}

Several issues currently impact the usefulness and success of mitigation translocations as a method to mitigate human impact on herpetofauna, and these can largely be summarised as a lack of "best-practice" protocols in salvage and post-release monitoring. According to International Union for Conservation of Nature (IUCN) guidelines, "best-practice" translocation protocols include controlling for the agent of decline, ensuring appropriate habitat in receptor sites, and conducting post-release monitoring (IUCN/SSC, 2013; Batson et al., 2015). These practices are enforced in conservation- or research-driven translocations, in which there is heavy investment in survival of individual animals. Even with a strong level of compliance towards IUCN protocols, conservation and research translocations are not always successful (Griffith et al., 1989; Germano \& Bishop 2009) and may have unpredictable challenges (Tuberville et al., 2005; Letty et al., 2007; Pérez et al., 2012). However, mitigation translocations rarely follow the IUCN best-practice protocols (Germano et al., 2015; Sullivan et al., 2015). In New Zealand, the Department of Conservation developed key principles of salvage and transfer of herpetofauna (Department of Conservation Lizard Technical Advisory Group, 2019); however, mitigation translocations specifically have not been reviewed for use of these principles (Cromarty \& Alderson, 2013; Wildland Consultants, 2019c). Key principles include defined goals and timeframes to evaluate measures of 
establishment and success post-release, appropriate surveying of salvage and receptor sites prior to translocation, permanent identification of individuals at salvage to assess survival and body condition changes, and post-release monitoring and reporting of results to wildlife and management agencies (Department of Conservation Lizard Technical Advisory Group, 2018; 2019; although see Wildland Consultants, 2019c).

In early translocation publications, the determinant of translocation success was defined as the establishment of a self- sustaining population (Giffith et al., 1989; Dodd \& Seigel, 1991). Miller et al. 2014 set smaller milestones (known as "stages") for translocation success such as 1. survival and growth of founders and 2. evidence of reproduction, that could be measured at earlier stages post-release. Romijn \& Hartley 2016 recommended timeframes to accurately evaluate these stages based on the slow life histories of New Zealand lizards (Cree \& Hare, 2016) - Stage 1 in $0-4$ years and Stage 2 in $5-9$ years post-release. However, thesecriteria to measure success often lack specific goals and timeframes for recapture rates and body condition assessments, making it difficult to assess the outcomes of the translocation in regard to conservation benefit or meeting legal obligations beyond relocating individuals. These criteria are also dependent on the use of permanent identifiers as they are best informedby analysing individual data over time post-release.

Few studies document outcomes of mitigation translocations. Those that do present concerning results. For example, Romijn \& Hartley (2016) reported only eight of 28 reviewed mitigation translocations provided post-release monitoring: only one translocation monitored within 4 years post-release reported more individuals captured than released and only one translocation reported findings 5 - 9 years post-release, but reported fewer individuals were captured than released. At the time of the review, no mitigation translocations were monitored beyond 10 years post-release. Lennon (2019) evaluated nine mitigation translocations 5 - $10+$ years after release and could not assess Stage 1 success due to the presence of a resident 
population at four of nine sites, lack of monitoring at a further two, and lack of permanent identifiers used in all translocations to separate translocated and resident individuals. Only twotranslocations met Stage 2 success, evidence of reproduction that could be directly linked to translocated groups, but this was only supported by finding one pregnant female and one juvenile overall (Lennon, 2019).

Legal obligations vary on resource consent permits and Wildlife Authority conditions, particularly around requirements for environmental offsetting (Brown et al., 2013; 2014; Lennon, 2019) and post-release monitoring to properly evaluate success or initiate adaptive management strategies (Miller et al., 2014; Germano et al., 2015; Romijn \& Hartley, 2016; Lennon 2019). Lennon (2019) evaluated compliance with legal obligations in nine mitigation translocations and reported that $71 \%$ met legal obligations stipulated by individual permits. However, the review also showed compliance to resource consent permit requirements (such as habitat enhancement and/or predator control) in mitigation translocations may not be enforced to a best practice standard (Brown, 2017). Financial compensation to the territorial authority may be provided instead, which may or may not directly benefit receptor sites and translocated groups (Brown et al., 2013; 2014; Le Coent et al., 2017; Lennon, 2019; Maseyk et al., 2018).

Although urbanization endangers native fauna in urban areas, many regional and city councils (territorial authorities) of New Zealand have developed biodiversity strategies to meet legal obligations to biodiversity in their boundaries of governance and encourage biodiversity presence in cities (Auckland Council, 2012; Greater Wellington Regional Council, 2016; Hawke's Bay Regional Council, 2015; Nelson City Council, 2018; Otago Regional Council, 2018; Taranaki Regional Council, 2012, 2017; Wellington City Council, 2015). Most biodiversity strategies are recently developed, in the early stages of research and plan implementation, and focus first on preserving natural areas in the council's jurisdiction. These 
tasks are made more difficult when important public works, such as public transport infrastructure, need improvements. A case study example of a development which called for amitigation translocation of lizards was the alteration to a cycleway in Wellington, New Zealand.

\subsubsection{Aims}

In this chapter, I report on post-release monitoring results for a case study involving the mitigation translocation of skinks from a development project in Wellington, New Zealand. I aim to evaluate and develop success criteria so they may be more widely applied to mitigation translocations and contribute to the decision-making over whether mitigation translocations should be used as a tool for urban developments.

Specifically, I asked the following questions:

1. Do lizards survive translocation? How do recapture rates at the receptor sites differ between translocated individuals and residents, and compare to recapture rates of control sites and other mitigation translocations?

2. Is condition of individuals affected by translocation? In particular, is there a difference between individuals translocated to a receptor site with and without a large resident population?

3. Is there evidence for population viability of translocated skinks in this case study? In the short term this requires survival and maintenance of condition of founders, evidence of recruitment, and recapture rates that increase over time.

\subsection{Methods}

\subsubsection{Salvage and post-release monitoring}

A cycleway development plan was proposed by Wellington City Council along Cobham Drive (henceforth referred to as the salvage site), a road in central Wellington city connecting Miramar Peninsula to the central business district in 2018 (Figure 2.1.). The development plans 
associated with the project endangered a population of northern grass skinks (O. polychroma) and plans for a mitigation translocation were put into motion in January 2019 following resource consent permit approval from the territorial authority (also Wellington City Council) and complying to national legal obligations (Wildlife Act, 1953; Resource Management Act, 1991; Wildland Consultants, Ltd., 2018). Northern grass skinks are a relatively short-lived species (3-5 years) when compared to most New Zealand lizards (5+ year life spans). They reach maturity at only $1.5-2$ years old and are live-bearing, producing 3-6 young per year (Daugherty et al., 1990; van Winkel et al., 2018). They are a small skink (up to 80mm; van Winkel et al., 2018) which seem to have maintained healthy populations within cities (often even in the presence of predators; Wooley et al., 2019) and a relatively large distribution, found in the lower half of the North Island and north-western parts of the South Island (Chapple \& Hitchmough, 2016; Hitchmough et al., 2016a).

The skink population at the salvage site was previously studied from November 2017 - December 2018, as part of an urban biodiversity project. Results from this study suggest the site hosted a dense population of northern grass skinks (8.13 skinks/100 trap days, Woolley, 2020). The site is coastal, north facing with an open canopy and habitat associated with this species such as low-growing taupata (e.g. Coprosma repens), harakeke/ kōrari (flax, Phorium tenax), and tall grasses like tussocks (van Winkel et al., 2018; Wildland Consultants, 2018; Woolley et al., 2019).

Three hundred and twenty-three baited 2-litre pitfall traps were deployed over six days in late January 2019 (subsequently referred to as the salvage event or session 5, Figure 2.2.). Over this time, 389 northern grass skinks (129 females (F), 124 males (M), and 136 juveniles (J)) were captured, measured, and 'marked' (permanent identifier in the form of unique toe codes) before release to one of two receptor sites (Figure 2.1. and 2.2.; Wildland Consultants, 2019a). 
Receptor site A is located on Mount Victoria, between the Wellington city centre and the salvage site (Figures 2.3.C.). This site provided open-canopied grasses and shrubbery with regenerating native bush; however, no skink presence was reported in previous monitoring efforts (Woolley, 2020). Receptor site B is in Houghton Bay, a south-facing bay similar in composition to the salvage site- an open-canopy coastal site with ample skink refugia in the form of tall grasses, native shrubs, and boulders (Figures 2.3.A. and D.). Receptor site B did not receive lizard monitoring prior to release, but northern grass skinks were observed during release of the translocated group and in post-release monitoring. One hundred individuals were released at receptor site A and 289 individuals were released at receptor site B in late January 2019 (Figures 2.2. and 2.3.; Wildland Consultants, 2019a).

Post-release monitoring (henceforth referred to as monitoring session 5.5) was conducted by contracted ecologists at receptor site A in January 2019 (Woolley, 2020) and receptor site B in March 2019 (Figure 2.2.; Wildland Consultants, 2019b). I monitored both receptor sites for four additional sessions from December 2019 - January 2021 (henceforth referred to as sessions 6-9; Figure 2.2.). Each summer had two sessions of ten days each, one in early summer (November/December) and one in late summer (January/February.) In session 5.5, monitoring methods and duration differed between the two receptor sites. Receptor site A initially involved a 5 x 5 grid of 4-litre pitfall traps; these were in place through the subsequent four monitoring sessions. I also installed additional traps in November 2019. These were pairs of pitfall traps placed 4 metres apart, installed at release points along the vegetation edge, for a total of 45 taps in monitoring sessions $6-9$ (Figure 2.3.C.). 
Post-release monitoring at release site B had paired pitfall traps installed along fifteen release points (total of thirty traps; Figure 2.3.D.). During the initial post-release monitoring session in March 2019, 2-litre pitfall traps were monitored over 7 days and removed at the end of the monitoring session (Wildland Consultants, 2019b). Paired pitfall traps were reinstalled using 4-litre buckets, and a grid of 8 x 3 pitfall traps was also established in December 2019, replacing one release point (two pitfall traps; Figure 2.3.D.), resulting in 52 traps total. 


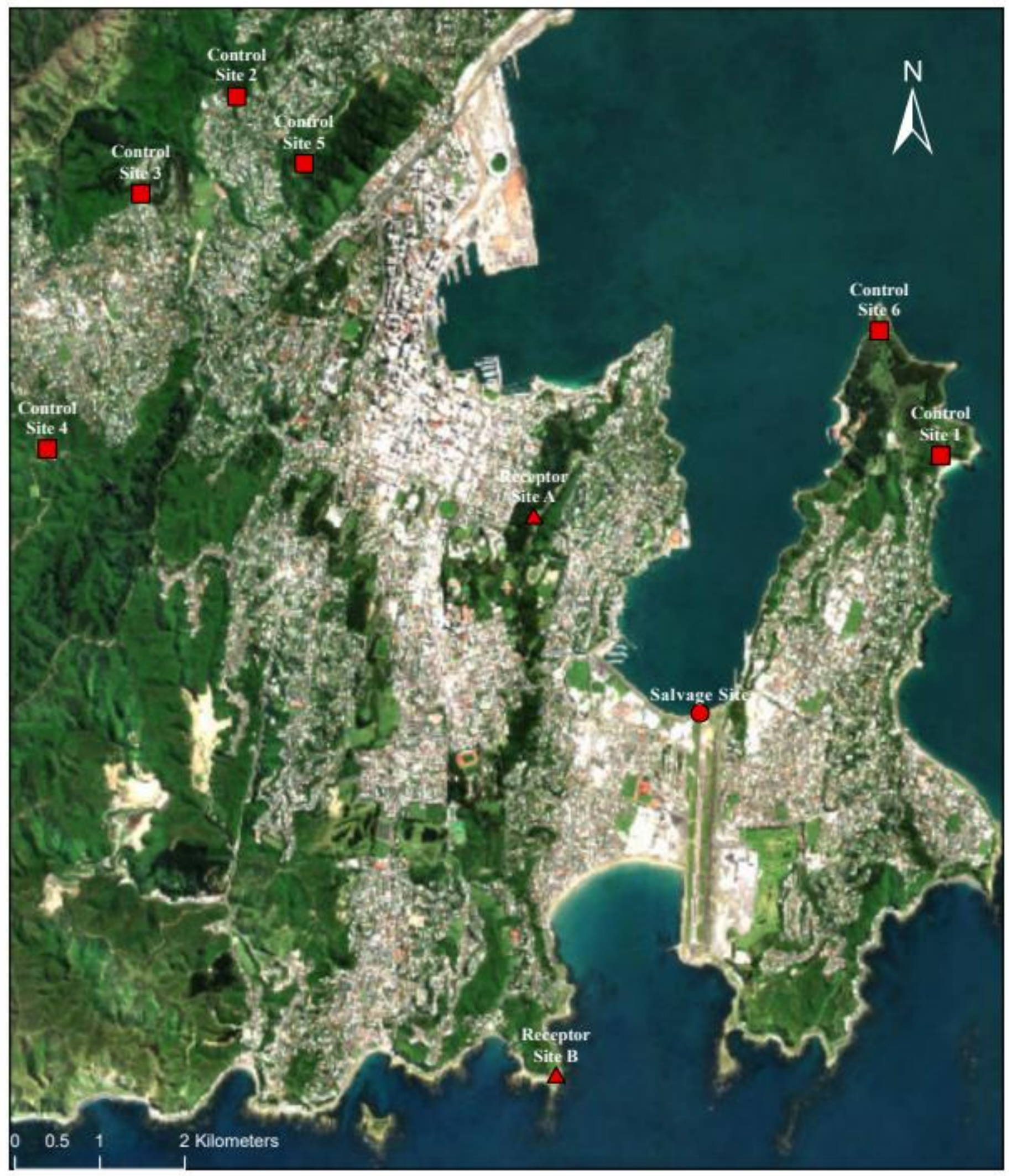

$\Delta$ Receptor Sites

Eagle Technology, Land Information New Zealand, GEBCO, Community maps

- Salvage Site contributors

$\square$ Control Sites

Figure 2.1.: Map of Wellington, New Zealand identifying control, salvage, and receptor sites. 


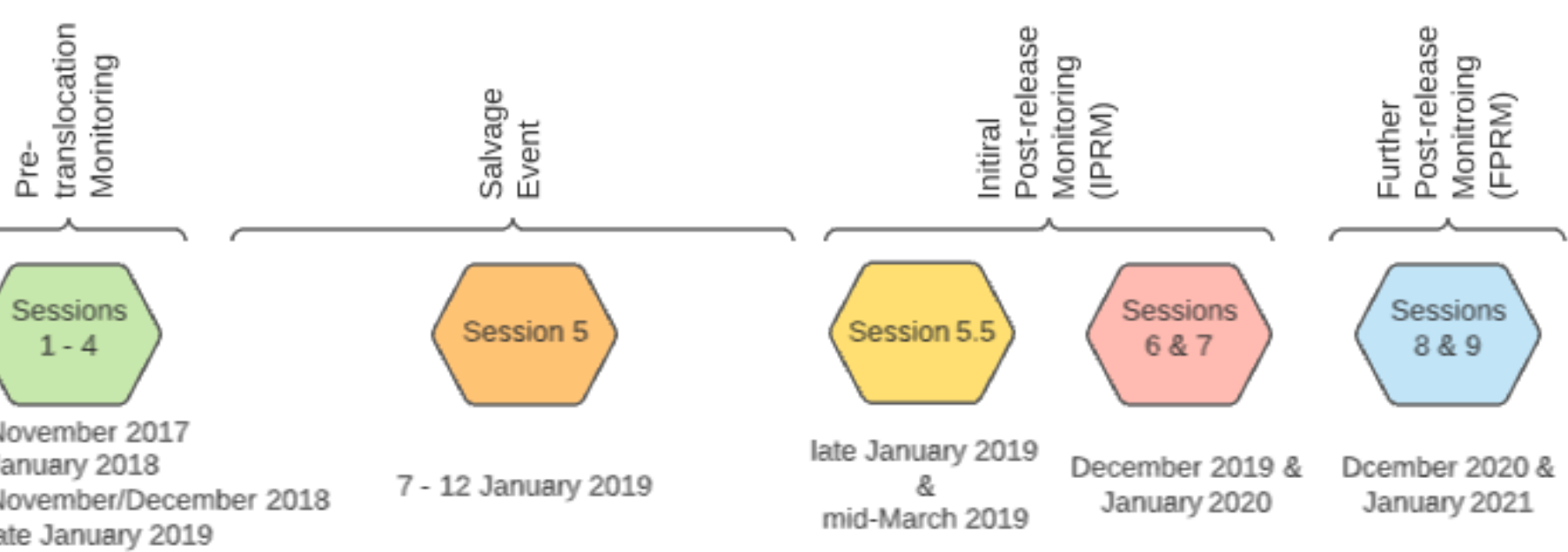

\begin{tabular}{|c|c|c|c|c|c|}
\hline $\begin{array}{c}\text { Control } \\
\text { Sites } \\
\text { Salvage } \\
\text { Site }\end{array}$ \\
\hline $\begin{array}{c}\text { Receptor } \\
\text { Site A }\end{array}$ \\
\hline Receptor \\
Site B
\end{tabular}

Figure 2.2.: Rows list sites monitored from 2017 - 2021 in the study, columns list sessions in in chronological order with associated phases. Diamonds represent lizard monitoring at a site for a given phase. Blank areas represent periodsthat a site was not monitored (the salvage site was not monitored post-salvage due to construction). The group translocated to receptor site A consisted of 27 females, 35 males, and 38 juveniles. The group translocated to receptor site B was comprised of 102 females, 89 males, and 98 juveniles 

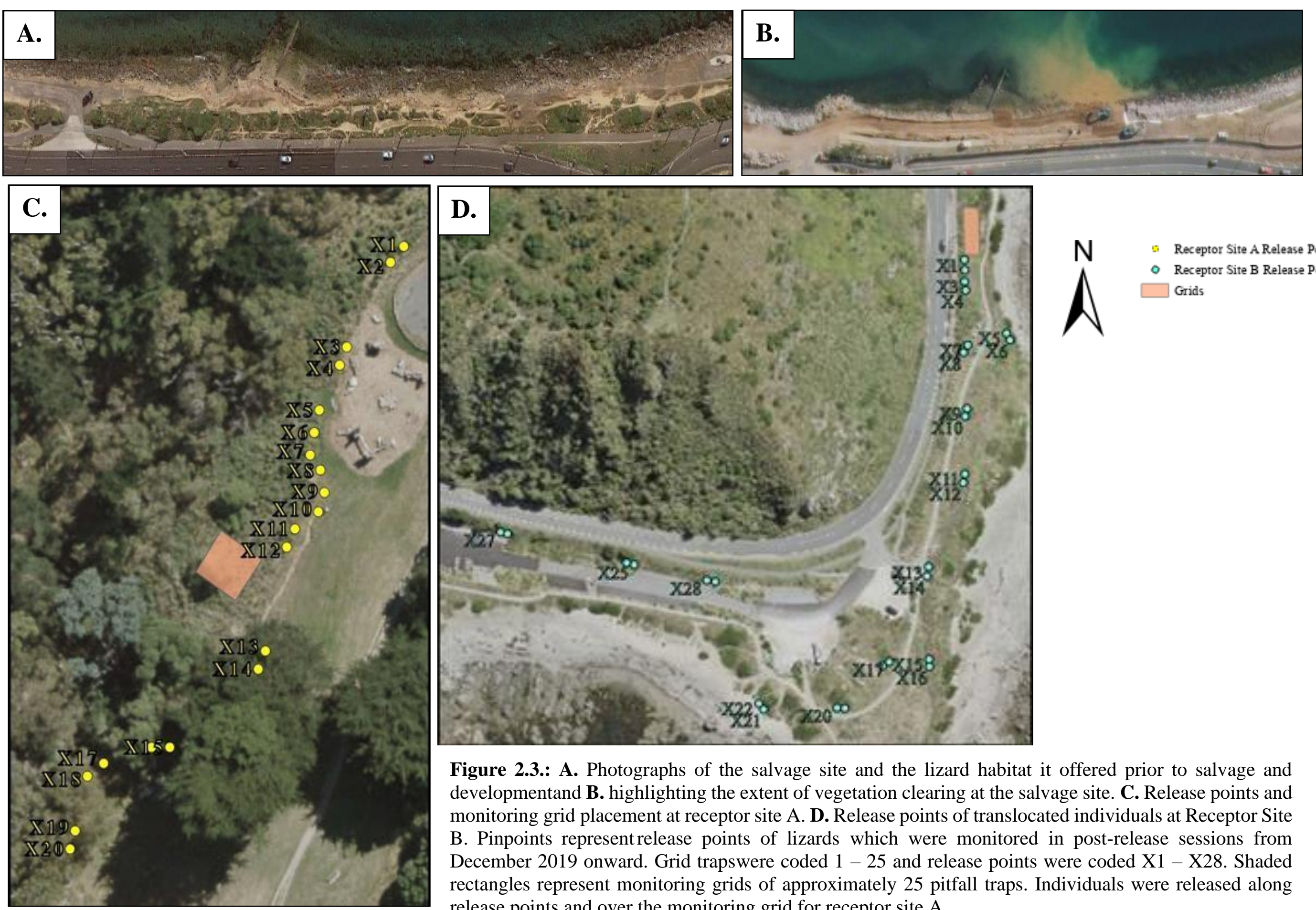

$N$

Receptor Site A Release Points

- Receptor Site B Release Points

$\square$ Grids

Figure 2.3.: A. Photographs of the salvage site and the lizard habitat it offered prior to salvage and developmentand B. highlighting the extent of vegetation clearing at the salvage site. C. Release points and monitoring grid placement at receptor site A. D. Release points of translocated individuals at Receptor Site B. Pinpoints represent release points of lizards which were monitored in post-release sessions from December 2019 onward. Grid trapswere coded $1-25$ and release points were coded X1 - X28. Shaded rectangles represent monitoring grids of approximately 25 pitfall traps. Individuals were released along release points and over the monitoring grid for receptor site A.

Adapted from lizard salvage and post-monitoring reports (Wildlands Consultants Ltd. 2018, 2019.)

Sourced from the LINZ Data Service and licensed for re-use under the Creative Commons Attribution 4.0 New Zealand licence 


\section{Control sites}

I reopened seven sites in Wellington used in an earlier urban biodiversity study (henceforth known as control sites 1 - 7; November 2017 - January 2019; Figure 2.2.; Woolley, 2020) to provide control for comparison with the salvage and translocation receptor sites. Previous trapping included 4-litre baited pitfall traps in a $5 \times 5$ grid, with traps 2 metres apart, opened for 10-day monitoring sessions twice a summer (250 trap nights/site/session, henceforth known as Pre-translocation phase: sessions $1-4$, Table 2.1.). I repeated this methodology for sessions $6-9$ at the control sites.

\section{Trapping}

Pitfall traps were installed so their top rim was flush with the substrate surface when open, with lids pinned in the ground, held slightly above the rim to allow access to skinks, provide shelter from the elements, and to deter predators. Inside each trap I installed wire mesh and leaf litter/grass to provide cover for lizards, a wet sponge $\left(2 \mathrm{~cm}^{2}\right)$, and piece of tinned pear as an attractant (Lettink et al., 2011; Hare, 2012; Woolley, 2020; although see Woolley et al., 2021). All material was restricted to the bottom $6 \mathrm{~cm}$ of the trap, ensuring skinks could not escape while the study was in session. Small holes (approx. $4 \mathrm{~mm}$ diameter) were drilled into the bottoms of buckets to allow for any trapped water to seep into the ground beneath. When closed, traps were emptied of contents, sealed using lids, and often covered over with dirt and vegetation.

In compliance with animal ethics permitting, traps were checked and rebaited daily. Captured skinks were released following body length and weight measurements and application of temporary identification, numbers marked on the right side of the individual using a silver xylene-free marker. Animals were given permanent identifiers by clipping the tip of one toe on each foot, known as a toe code (Lettink \& Hare, 2016). Toe codes were applied 
to all individuals captured in the Pre-translocation phase. In post-release monitoring, toe coding only occurred at receptor sites to compare resident individuals (those inhabiting the site prior to the translocation) to translocated individuals which were toe coded at salvage. Toe codes did not overlap between translocated individuals and resident individuals within sites.

\subsubsection{Data collection}

Species were identified using distribution data and physical characteristics from recently published lizard field guides (van Winkel et al., 2018). Measurements included snout-vent length $(\mathrm{SVL}, \pm 1 \mathrm{~mm})$, total length $( \pm 1 \mathrm{~mm})$, tail regeneration/loss $( \pm 1 \mathrm{~mm})$, mass $( \pm 5 \mathrm{~g})$, trap number, and release/ recapture location at receptor sites (X-, Y-coordinates). Every individual was sexed $(\mathrm{M} / \mathrm{F})$ by eversion of hemipenes in male skinks as northern grass skinks do not have externally distinguishable sexual dimorphism. Individuals with a snout-vent length under 45 mm were assigned 'juvenile' (J) as sex could not be determined. Reproductive status (potentially pregnant/NA) was assigned based on visual assessment and light palpation of the abdomen. Toe codes were recorded, if present or when assigned to residents. Competency sexing individuals and assessing reproductive status improved over time. As thiswas the case, these variables are only used to report summary statistics and as a guide to assessevidence of reproduction (Stage 2 short-term success criteria, Miller et al., 2014).

\subsubsection{Statistical analyses}

All analyses were conducted in R v. 3.5.1. (R Core Team, 2018). Two types of record were analysed: the number of observations and number of individuals. Observations (also known as captures) were used to calculate catch per unit effort (CPUE) and the number of individuals was used to calculate recapture rates for each skink classification (resident, translocated, control) and for body condition analyses. 


\section{Catch per unit effort (CPUE)}

Catch per unit effort (CPUE) reports the number of observations per 100 trap days and is a common method for reporting results from monitoring. Trap days were calculated by multiplying the number of traps deployed by number of days monitored, divided by 100 . As monitoring sessions changed in duration in the final session of the study and the number of traps per site varied between receptor sites and control sites, CPUEs serve as a standardized measurement for representative group numbers at each site (Table 2.1.), but do not accurately report the number of individuals captured and recaptured in a session.

\section{Recapture rates}

All individuals which could be accurately identified via toe code were included in recapture rate calculations. A recapture is defined as capture of an individual in any session following marking, hence an individual caught twice in session 6 and once in session 8 would only count as one recapture (Eifler \& Eifler, 1999). Recapture rates of translocated individuals at receptor sites were calculated by counting the number of individuals recorded out of the number translocated to the site. Resident and control recaptures were calculated similarly, counting the number of recaptured "marked individuals" (individuals with a reliabletoe code) out of the total number of marked individuals. Recapture rates are reported cumulatively for all sessions that used toe coding and by session.

\section{Recapture Location}

Individual dispersal from release site is reported strongest in the first weeks to months following release and is a key determinant of success (Tuberville et al., 2005; Ebrahimi \& Bull, 2013; Angeli et al., 2018); if individuals are not recaptured they could have died ordispersed outside the trapping area. I calculated the distance between recapture locations and release point locations as a measure of dispersal. I noted how many translocated individuals were 
recaptured at or within 10 metres of their release points at different time points since release as a measure of how many individuals anchored to release sites (Figures 2.3.C. and D.;based on current knowledge of Oligosoma home ranges (Eifler \& Eifler, 1999; Wilson et al., 2017)).

\section{Body Condition Analyses}

Stress (Teixeira et al., 2007), resource availability (Eifler \& Eifler, 1999; Ebrahimi \& Bull, 2012), appropriate habitat (Ebrahimi \& Bull, 2013; Gallego- Carmona et al., 2016), and competition are a few factors which are known to effect reptile body conditions, and therefore body condition is used as a surrogate forfitness or health for adult lizards (Moore et al., 2007). Only records from individuals which could be accurately identified using toe codes were used for individual body condition analyses. Juveniles, pregnant females (Boretto et al., 2014; Dayger et al., 2018), and individuals with tail loss (tails with no regeneration) were excluded from all body condition analyses as these factors greatly impact traditional body condition index (BCI) calculations (Hoare et al., 2006). Mass and SVL were log-transformed to conform to residual best fit and BCI was calculated as such: $\log _{10}(\operatorname{mass}(\mathrm{g})) / \log _{10}(\mathrm{SVL}(\mathrm{mm}))$.

The direct effect the translocation may have had on body condition changes of translocated and resident individuals cannot be tested in this project due to the lack of access to the salvage site which would serve as a control site and no prior monitoring conducted to assess resident populations and conditions at release sites. Instead, records of recaptured individuals' BCI at years one and two post-release were compared to their respective BCI records from salvage. A Kruskal-Wallis test compared BCI of translocated groups by receptor site. A two-way analysis of variance (ANOVA) was used to assess the relationship between individual type, and session (time) on BCI. Post-hoc tests used were the Wilcoxon signed rank test for differences in BCI 
between sessions and a Tukey's test for differences in mean BCI between the three groups: translocated, resident, and control. To ensure data was not confounded by seasonal differences these analyses only considered data from late summer (January/February) sessions in 2020 and 2021. Late summer was chosen as females are likely in late stages of pregnancy and more identifiable (Hare, 2012; Cree \& Hare, 2016). March post-release monitoring (session 5.5) for receptor site B was excluded to avoid seasonality effects.

\subsection{Results}

\subsubsection{Catch per unit effort (CPUE)}

The only species regularly captured was $O$. polychroma (northern grass skinks), but Oligosoma aeneum (copper skinks) was also recorded at two control sites in low abundance (10 individuals recorded in sessions 6 - 9). Consequently, all further presentation of results focuses on northern grass skinks. Unmarked skinks were captured at receptor site A for the first time during this study. Without genetic analysis, it cannot be confirmed whether these individuals were born of translocated females or females residing at the site pre-translocation. Their SVL measurements were within the range of distinction between juvenile and adult (32-54 mm; Barwick, 1959; Hare et al., 2016) indicating they are young enough to be new recruits from the translocation.

There were twenty-one observations of northern grass skinks over four monitoring sessions at receptor site A (1825 trap days, CPUE $=1.2$ skinks $/ 100$ trap days). Of these, 14 were observations of translocated individuals (CPUE $=0.8$ skinks/100 trap days) and seven were observations of resident individuals (CPUE $=0.4$ skinks/100 trap days). There were two hundred and twenty observations of northern grass skinks over the same monitoring sessions at receptor site B (2030 trap days, CPUE = 10.8 skinks/ 100 trap days); 101 were observations of translocated individuals $(\mathrm{CPUE}=5.0$ skinks/100 trap days $)$ and 119 were observations of 
resident skinks (CPUE $=5.9$ skinks/100 trap days). Averaged across all sessions, the CPUE of translocated skinks was higher at receptor site B than site A (5.0 and 0.8 translocatedskinks/100 trap days, respectively). Resident CPUE was also higher at site B than site A (5.9 and 0.4 skinks/100 traps days, respectively; Table 2.1.).

The CPUE of receptor site A residents increased over time after their initial appearance in session 6 until session 9. Detection of residents and translocated individuals fluctuated betweensessions in the two years following the translocation (Table 2.1.). When translocated skinks were released at receptor site B, resident skinks were observed using release point pitfall traps.As time since release increased, the catch of both residents and translocated individuals at thesite increased similarly (approximately 1.0 skink/ 100 trap days (session 6) and 3.0 skinks/ 100trap days in (session 7) for both groups). Overall, resident CPUE was slightly higher than the translocated CPUE at receptor site B (5.9 and 5.0 skinks/ 100 trap days, respectively).

The number of observations at control sites ranged from 8 - 54 captures per site in monitoringsessions $6-9$ (1875 trap days, $\mathrm{CPUE}=1.0$ to 9.0 skinks/ 100 trap days $)$ with small fluctuationswithin a site among sessions (Table 2.1.). The salvage site and control site 4 had the highest CPUEs in the Pre-translocation (pre-salvage) phase. The CPUE of translocated individuals at both receptor sites fell below the historical CPUE at the salvage site $(0.8$ and 5.0 skinks/100 traps days compared to 8.1 skinks/100 trap days, Table 2.1.). CPUE of all observations at receptorsite A (1.2 skinks/100 trap days) is low compared to control sites which reported captures (anaverage of 3.46 skinks/ 100 days for 5 sites across all sessions). CPUE of all captures at receptorsite B (6.8 skinks/100 trap days) is above the average control site CPUE. 
Table 2.1. (next page): The top section details trap days per site by session, show changes in trap days over the study (either due to changes in traps deployed or reduced study days). The middle section details the number of individuals caught by site per session (session total) and the number of individuals recaptured by session. Receptor sites are split to represent translocated (T) and resident (R) groups separately. Totals are listed on the right side of the table. Recapture rates are calculated by dividing the total number of marked individuals by the number recaptured in subsequent monitoring sessions. Totals for the salvage site include Pre-translocation phase only. Grey boxes represent no monitoring or removal from the study (salvage site). The bottom section details CPUE by session with site averages listed on the right.

* denotes recapture rates of translocated individuals, calculated using the number of individuals translocated to respective sites

** refers to the average CPUE of a site using data from sessions $1-4$ and the salvage site, calculated excluding the CPUE of the salvage event 


\begin{tabular}{|c|c|c|c|c|c|c|c|c|c|c|}
\hline \multirow{2}{*}{\begin{tabular}{|l} 
Trap Days \\
Control Sites
\end{tabular}} & \multirow{3}{*}{$\begin{array}{c}1250 \\
250\end{array}$} & \multirow[b]{2}{*}{1250} & \multirow[b]{2}{*}{1250} & \multirow[b]{2}{*}{1250} & \multirow[b]{2}{*}{ N/A } & \multirow[b]{2}{*}{ N/A } & \multirow[b]{2}{*}{1250} & \multirow[b]{2}{*}{1000} & \multirow[b]{2}{*}{1000} & \multirow[b]{2}{*}{1000} \\
\hline & & & & & & & & & & \\
\hline Salvage Site & & 250 & 250 & 250 & 1615 & N/A & $\mathrm{N} / \mathrm{A}$ & N/A & N/A & N/A \\
\hline Receptor Site A & 250 & 250 & 250 & 250 & N/A & 250 & 450 & 450 & 450 & 225 \\
\hline Receptor Site B & N/A & N/A & N/A & N/A & N/A & 210 & 520 & 520 & 520 & 260 \\
\hline
\end{tabular}

\begin{tabular}{|c|c|c|c|c|c|c|c|c|c|c|c|c|c|}
\hline \multirow[t]{2}{*}{$\begin{array}{l}\text { Individuals Captured } \\
\text { Total Individuals }\end{array}$} & & \multicolumn{4}{|c|}{ Control } & \multirow{2}{*}{$\begin{array}{l}\text { Salvage } \\
\text { Session } 5 \\
\end{array}$} & \multicolumn{3}{|c|}{ Initial post-release monitoring } & \multicolumn{2}{|c|}{ Cont. post-release monitoring } & \multirow{2}{*}{\begin{tabular}{|c|}
$\begin{array}{c}\text { Total Individuals } \\
\text { (No. of Marked Individuals) }\end{array}$ \\
\\
No. of Recaptured Individuals
\end{tabular}} & \multirow{2}{*}{$\begin{array}{c}\text { Recap. Rate } \\
\text { (Recaptured } \\
\text { Individuals } \\
\text { Marked } \\
\text { Individuals) } \\
\end{array}$} \\
\hline & & \multirow{2}{*}{$\frac{\text { Session } 1}{34}$} & \multirow{2}{*}{$\begin{array}{c}\text { Session } 2 \\
17 \\
2 \\
\end{array}$} & \multirow{2}{*}{$\begin{array}{c}\text { Session } 3 \\
10 \\
0 \\
\end{array}$} & \multirow[t]{2}{*}{ Session 4} & & Session 5.5 & Session 6 & Session 7 & Session 8 & Session 9 & & \\
\hline Salvage Site & $\begin{array}{l}\text { Session Total } \\
\text { Recaptures }\end{array}$ & & & & & $\begin{array}{c}389 \\
8\end{array}$ & & & & & & \begin{tabular}{|c|}
$61(61)$ \\
2
\end{tabular} & $3.3 \%$ \\
\hline Receptor Site A - T & $\begin{array}{l}\text { Session Total } \\
\text { Recaptures }\end{array}$ & & & & & & $\begin{array}{l}3 \\
3\end{array}$ & $\begin{array}{l}2 \\
2\end{array}$ & $\begin{array}{l}5 \\
3\end{array}$ & $\begin{array}{l}3 \\
0\end{array}$ & $\begin{array}{l}1 \\
1\end{array}$ & $\begin{array}{c}14(14) \\
9\end{array}$ & $9.0 \% *$ \\
\hline Receptor Site A - R & $\begin{array}{l}\text { Session Total } \\
\text { Recaptures }\end{array}$ & 0 & 0 & 0 & 0 & & 0 & $\begin{array}{l}1 \\
0\end{array}$ & $\begin{array}{l}2 \\
0\end{array}$ & $\begin{array}{l}5 \\
0\end{array}$ & $\begin{array}{l}0 \\
0\end{array}$ & $\begin{array}{c}8(8) \\
0\end{array}$ & $0.0 \%$ \\
\hline Receptor Site B - T & $\begin{array}{l}\text { Session Total } \\
\text { Recaptures }\end{array}$ & & & & & & $\begin{array}{l}10 \\
10 \\
\end{array}$ & $\begin{array}{l}6 \\
6 \\
\end{array}$ & $\begin{array}{c}10 \\
8\end{array}$ & $\begin{array}{l}8 \\
3 \\
\end{array}$ & $\begin{array}{c}14 \\
7 \\
\end{array}$ & $\begin{array}{c}48(48) \\
34 \\
\end{array}$ & $11.8 \% *$ \\
\hline Receptor Site B - R & $\begin{array}{l}\text { Session Total } \\
\text { Recaptures }\end{array}$ & & & & & & 3 & 5 & $\begin{array}{c}15 \\
1 \\
\end{array}$ & $\begin{array}{c}22 \\
3 \\
\end{array}$ & $\begin{array}{l}26 \\
10 \\
\end{array}$ & $\begin{array}{c}71(68) \\
14 \\
\end{array}$ & $20.6 \%$ \\
\hline Control Site 1 & $\begin{array}{l}\text { Session Total } \\
\text { Recaptures }\end{array}$ & 2 & $\begin{array}{l}0 \\
0 \\
\end{array}$ & $\begin{array}{l}1 \\
0 \\
\end{array}$ & $\begin{array}{l}4 \\
0 \\
\end{array}$ & & & $\begin{array}{l}5 \\
1 \\
\end{array}$ & 3 & 6 & 5 & $\begin{array}{c}26(7) \\
1 \\
\end{array}$ & $14.3 \%$ \\
\hline Control Site 2 & $\begin{array}{l}\text { Session Total } \\
\text { Recaptures }\end{array}$ & 1 & $\begin{array}{l}7 \\
0 \\
\end{array}$ & $\begin{array}{l}5 \\
2 \\
\end{array}$ & $\begin{array}{l}10 \\
4 \\
\end{array}$ & & & 0 & 6 & 1 & 1 & $\begin{array}{c}31(23) \\
6 \\
\end{array}$ & $26.1 \%$ \\
\hline Control Site 3 & $\begin{array}{c}\text { Session Total } \\
\text { Recaptures } \\
\end{array}$ & 0 & $\begin{array}{l}6 \\
0 \\
\end{array}$ & $\begin{array}{l}1 \\
0 \\
\end{array}$ & $\begin{array}{r}26 \\
2 \\
\end{array}$ & & & 7 & 5 & 9 & 4 & $\begin{array}{c}58(33) \\
2 \\
\end{array}$ & $6.1 \%$ \\
\hline Control Site 4 & $\begin{array}{l}\text { Session Total } \\
\text { Recaptures }\end{array}$ & 23 & $\begin{array}{c}59 \\
8\end{array}$ & $\begin{array}{c}13 \\
5\end{array}$ & $\begin{array}{c}25 \\
6\end{array}$ & & & 1 & $\begin{array}{c}17 \\
5\end{array}$ & 21 & 15 & $\begin{array}{c}174(120) \\
24\end{array}$ & $20.0 \%$ \\
\hline
\end{tabular}

\begin{tabular}{|c|c|c|c|c|c|c|c|c|c|c|c|}
\hline \multirow{2}{*}{$\begin{array}{l}\text { CPUE } \\
\text { (Number of observations/ } 100 \text { trap davs) }\end{array}$} & \multicolumn{4}{|c|}{ Control } & \multirow{2}{*}{$\begin{array}{r}\text { Salvage } \\
\text { Session } 5 \\
\end{array}$} & \multicolumn{3}{|c|}{ Initial post-release monitoring } & \multicolumn{2}{|c|}{ Cont. post-release monitoring } & \multirow[b]{2}{*}{ Average CPUE } \\
\hline & Session 1 & Session 2 & Session 3 & Session 4 & & Session 5.5 & Session 6 & Session 7 & Session 8 & Session 9 & \\
\hline \begin{tabular}{|l|l|} 
Salvage Site & \\
\end{tabular} & 13.6 & 6.8 & 4.0 & & 24.1 & & & & & & $8.1 * *$ \\
\hline Recptor Site A - T & & & & & & 1.2 & 0.4 & 1.1 & 0.7 & 0.4 & 0.8 \\
\hline Receptor Site A - R & 0.0 & 0.0 & 0.0 & 0.0 & & 0.0 & 0.2 & 0.4 & 1.1 & 0.0 & 0.4 \\
\hline Receptor Site B - T & & & & & & 4.8 & 1.2 & 3.1 & 5.4 & 10.4 & 5.0 \\
\hline Receptor Site B - R & & & & & & 1.4 & 1.0 & 3.3 & 9.2 & 14.6 & 5.9 \\
\hline Control Site 1 & 0.8 & 0.0 & 0.4 & 1.6 & & & 2.0 & 1.2 & 4.8 & 4.0 & 3.0 \\
\hline Control Site 2 & 0.4 & 2.8 & 2.0 & 4.0 & & & 0.0 & 2.4 & 0.8 & 0.8 & 1.0 \\
\hline Control Site 3 & 0.0 & 2.4 & 0.4 & 10.4 & & & 2.8 & 2.0 & 7.2 & 3.2 & 3.8 \\
\hline Control Site 4 & 9.2 & 23.6 & 5.2 & 10.0 & & & 0.4 & 6.8 & 16.8 & 12.0 & 9.0 \\
\hline Control Site 5 & 0.0 & 0.0 & 0.0 & 0.0 & & & 0.0 & 0.0 & 0.0 & 0.0 & 0.0 \\
\hline Control Site 6 & 0.8 & 0.8 & 0.0 & 0.4 & & & 0.0 & & & & $0.5^{* *}$ \\
\hline
\end{tabular}




\subsubsection{Recapture rates}

Three translocated individuals were recaptured in session 5.5 at receptor site A, the first reported skinks at the site since monitoring began in November 2017 (Woolley, 2020). Ten translocated individuals were recaptured in session 5.5 at receptor site B along with 3 resident individuals, for a total of thirteen observations (Table 2.2.; Wildland Consultants, 2019b). Cumulatively, 43 of 389 translocated individuals (11.1\%) were recaptured over 2 years of postreleasemonitoring between both receptor sites. Thirteen of these were juveniles at the time of salvage, and these represent $30 \%$ of the total number of translocated juveniles. Receptor sites individually reported similar recapture rates over sessions $5.5-9: 9.0 \%$ of the animals released at receptor site A were recaptured and $11.8 \%$ at receptor site B (Table 2.1. and Figure 2.4.).

Residents of receptor site A were occasionally recaptured within a 10-day monitoring session but were not recaptured in subsequent monitoring sessions and therefore had arecapture rate of $0 \%$ for residents over all monitoring sessions. Of 68 marked residentindividuals captured in post-release monitoring at receptor site B, 14 were recaptured again insubsequent sessions $(20.6 \%)$. At receptor site B, resident captures and recaptures increased over time. Recapture rates at control sites ranged from $0-26.1 \%$ over three sessions, that is, based on comparative effort to receptor sites, with the highest number of recaptured individuals at control site $4(20.0 \%)$. Overall recapturerates at the receptor sites (and of the general translocation $11.0 \%$ ) were within the range of those found at the control sites. The recapture rate of residents at receptor site B is quite high $(20.6 \%)$ when compared to the cumulative translocation recapture rate $(11.8 \%)$ and also with control sites (surpassed only by control site 3 , which had a low total catch but high recapture rate, 26.1\%; Table 2.1. and Figure 2.4.). 
Recapture rates of translocated individuals in the first two post-release sessions were similar between receptor site A (session 5.5: 3\%, session 6: $2 \%$ ) and receptor site B (session 5.5: $3.5 \%$, session $6: 2.1 \%$ ). As time passed, recapture rates of translocated individuals declined at receptor site A but increased at receptor site B. Both receptor sites had higher recapture rates of translocated individuals than early recapture rates at control sites, except for control site 4 which showed $34.8 \%$ of individuals marked in session 1 recaptured in the following session. The recapture rate of residents at receptor site B were low in early sessions (6 and 7) but improved over time (Figure 2.4.).

The salvage site was monitored from November 2017 - November 2018. Only two of sixty-one individuals were recaptured again prior to the salvage event. This makes the recapture rate $2.0 \%$ over one year (3 monitoring sessions.) Eight different individuals which were marked during the control monitoring period were recaptured during the salvage event $(2.06 \%$ of 389 individuals captured.) 


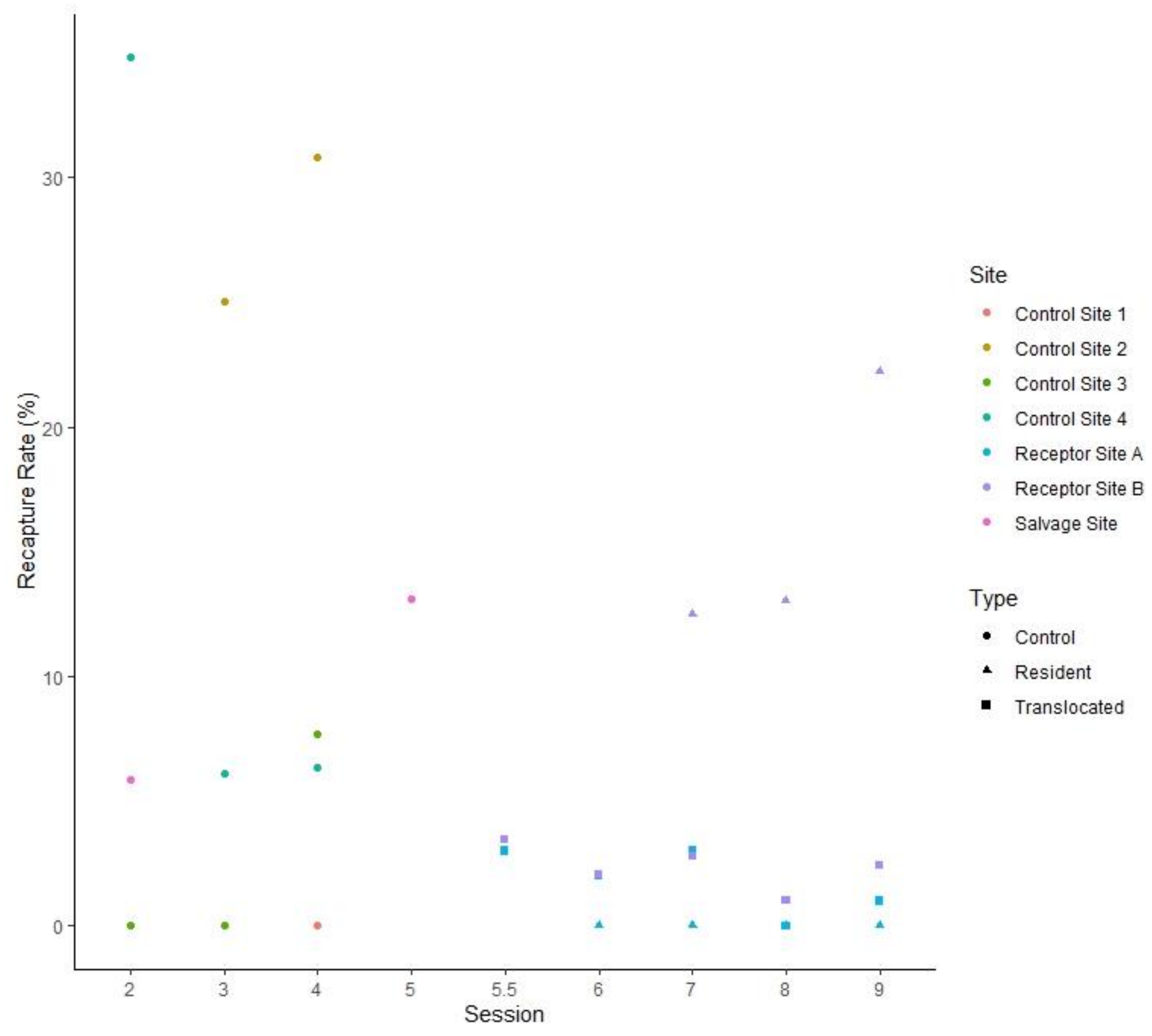

Figure 2.4: Scatterplot of recapture rate $(\%)$ by site reported for each session. Recapture rates were assessed for control sites from session $2-4$ and for receptor sites over sessions $5.5-9$. Point shape and colour represent individual type classification: Translocated (T), Resident (R), or Control (C) and site ID, respectively. 


\subsubsection{Dispersal}

Of the nine translocated individuals recaptured at receptor site A, seven were recaptured at or within 10 metres of their respective release points. One of the individuals moved away from their release point (over the previously established monitoring grid in a cool, dense forest) to the top of the monitoring grid, which has an open canopy with dense shrubbery and meets an open grass area (recaptured in X11, a movement of approx. 20 metres, Figure 2.3.C.). Movement towards the top of the hill was recorded during the first monitoring session following the translocation (less than 1 month after release) and the individual consistently stayed at the shrub/grass edge over the next two summers. The other translocated individual was recaptured over 30 metres away from its release point, along the release point route which followed a shrub/grass vegetational edge (monitoring grid to X18, Figure 2.3.C.).

Eight translocated individuals were recorded at traps over 10 metres away from their release points at receptor site B. Four moved from release points close to the shore (X5/X6) towards the grassy area which held the monitoring grid, with one individual traveling approximately 90 metres from release points X11/12 to the northern part of the monitoring grid. The other three moved from X5/6 to X1/2 or X3/4 (approximately 25 metres, Figure 2.3.D.). Only two resident individuals were recaptured over time over 10 metres from their original capture point. One travelled through the grassy area from the northern part of the grid to X4 (approx. 30 metres) within four days. The other skink travelled from X5 at the coast to X1 (25 metres) over two days.

\subsubsection{Body condition changes}

Twenty-two of the 43 recaptured translocated skinks met criteria for inclusion in the BCI analyses (Table 2.2., Figure 2.5.). The average BCI at salvage was $0.27 \pm 0.01$ SEM. Postrelease $\mathrm{BCI}$ increased from salvage BCI at both receptor sites in session 5.5, but was higher at 
receptor site A (at $0.36-0.45)$ than at receptor site B $(0.28-0.40)$. Six individuals were recaptured in the period one to three months post-release (session 5.5) between both receptor sites, one-half showed a slight decrease in body condition and one half showed consistent or slight increases (Figure 2.5.). Only two of the individuals captured at session 5.5 were recaptured in later sessions. No individuals which reported a decreased body condition in the first three months following the translocation were recaptured again. Site did not show an effect on BCI of translocated individuals $(\mathrm{df}=1, \mathrm{H}=1.19, \mathrm{p}=0.28)$ or resident individuals $(\mathrm{df}=1$, $\mathrm{H}=1.58, \mathrm{p}=0.21)$ in post-release monitoring.

Table 2.2.: Morphometric data of recaptured translocated individuals which met body condition criteria (SVL over $45 \mathrm{~mm}$ and non-pregnant). Acronyms used: SVL = snout-vent length, BCI = body condition index $(\log 10$ (mass)/log10 (SVL)).

\begin{tabular}{|c|c|c|c|c|}
\hline \multirow{2}{*}{ Type and Session } & & SVL (mm) & Mass (g) & $\mathrm{BCI}$ \\
\hline & $\mathrm{n}$ & Mean (SE) & Mean (SE) & Mean (SE) \\
\hline \multicolumn{5}{|l|}{ Salvage } \\
\hline 5 & 24 & $56.00(1.06)$ & $3.03(0.13)$ & $0.27(0.01)$ \\
\hline \multicolumn{5}{|l|}{ Receptor Site A } \\
\hline 5.5 & 2 & 63.50 & 4.35 & 0.35 \\
\hline 6 & 1 & 62.00 & 5.15 & 0.40 \\
\hline 9 & 1 & 71.00 & 4.70 & 0.36 \\
\hline \multicolumn{5}{|l|}{ Receptor Site B } \\
\hline 5.5 & 5 & $58.2(1.46)$ & $3.20(0.19)$ & $0.28(0.01)$ \\
\hline 6 & 2 & 59.00 & 3.65 & 0.40 \\
\hline 7 & 5 & $61.00(1.52)$ & $4.49(0.28)$ & $0.36(0.01)$ \\
\hline
\end{tabular}




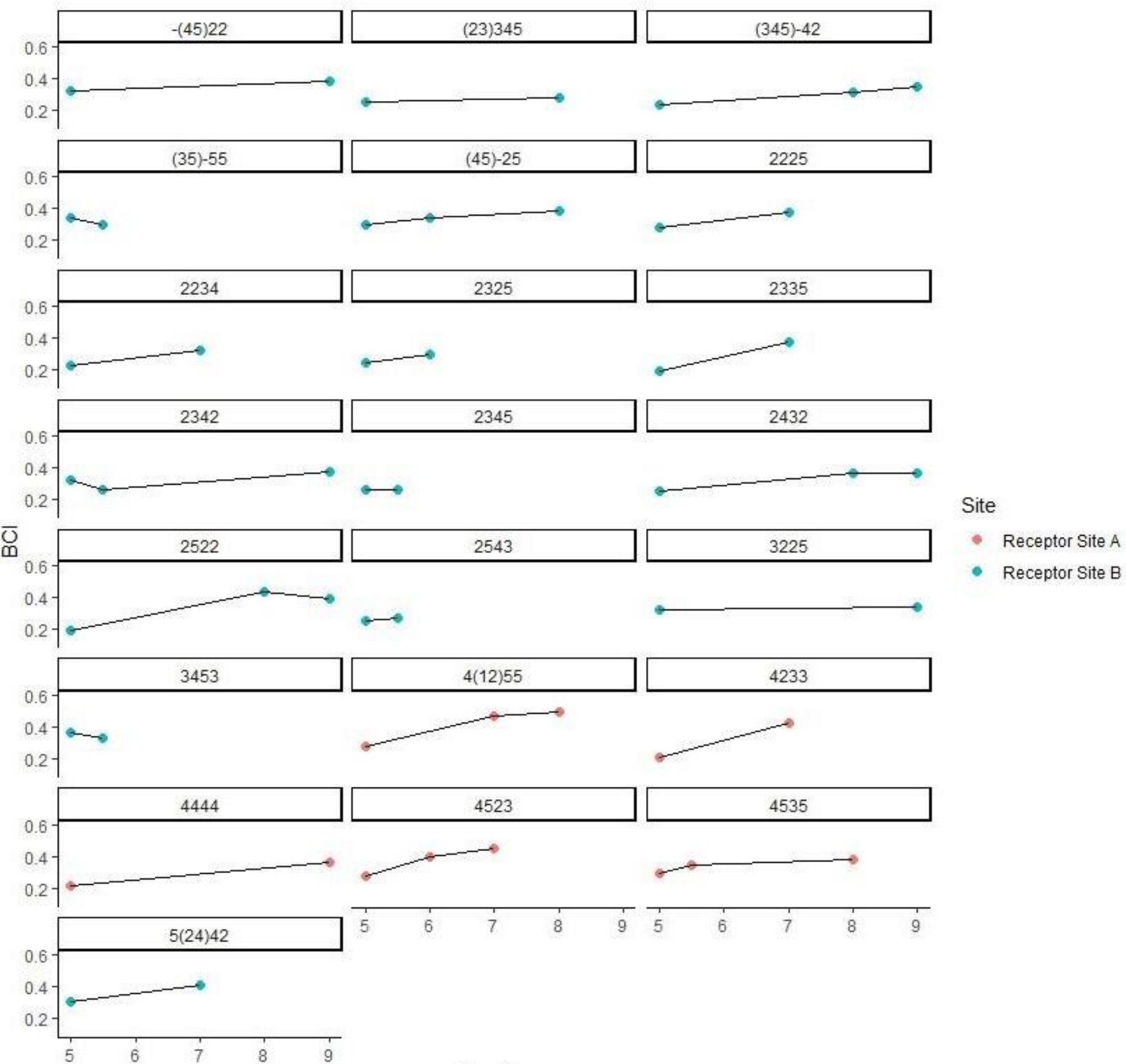

Session

Figure 2.5.: Graphs for individual changes in body condition (BCI) for lizards translocated from the Cobham Drive translocation plotted over all post-release monitoring sessions. Toe codes (i.e. 4535) title individual graphs. Colours coordinate individuals with their respective receptor site. Session 5 refers to the salvage event in January 2019. Individuals were recaptured at different times, and few were recaptured in multiple postrelease sessions, as shown in the individual plots. 
Table 2.3.: Morphometric data for all individual types used for population average BCI changes between January 2020 (S7) and January 2021 (S9). These represent the types grouped together to include all non-pregnant, adult individuals at sites associated with type (receptor sites A and B are compounded to become "Translocated".)

\begin{tabular}{|c|c|c|c|c|}
\hline \multirow{2}{*}{ Type and Session } & & SVL (mm) & Mass (g) & $\mathrm{BCI}$ \\
\hline & $\mathrm{n}$ & Mean (SE) & Mean (SE) & Mean (SE) \\
\hline \multicolumn{5}{|l|}{ Translocated } \\
\hline 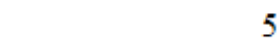 & 14 & $56.60(1.46)$ & $3.01(0.13)$ & $0.27(0.01)$ \\
\hline 7 & 3 & $63.00(1.15)$ & $7.00(0.21)$ & $0.47(0.01)$ \\
\hline 9 & 7 & $62.90(1.56)$ & $4.63(0.19)$ & $0.37(0.01)$ \\
\hline \multicolumn{5}{|l|}{ Resident } \\
\hline 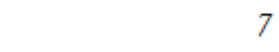 & 9 & $53.60(0.75)$ & $5.47(0.13)$ & $0.43(0.01)$ \\
\hline 9 & 24 & $58.00(0.92)$ & $3.53(0.16)$ & $0.31(0.01)$ \\
\hline \multicolumn{5}{|l|}{ Control } \\
\hline 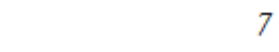 & 12 & $53.80(0.97)$ & $5.32(0.17)$ & $0.42(0.01)$ \\
\hline 9 & 21 & $54.90(1.28)$ & $3.25(0.21)$ & $0.28(0.01)$ \\
\hline
\end{tabular}

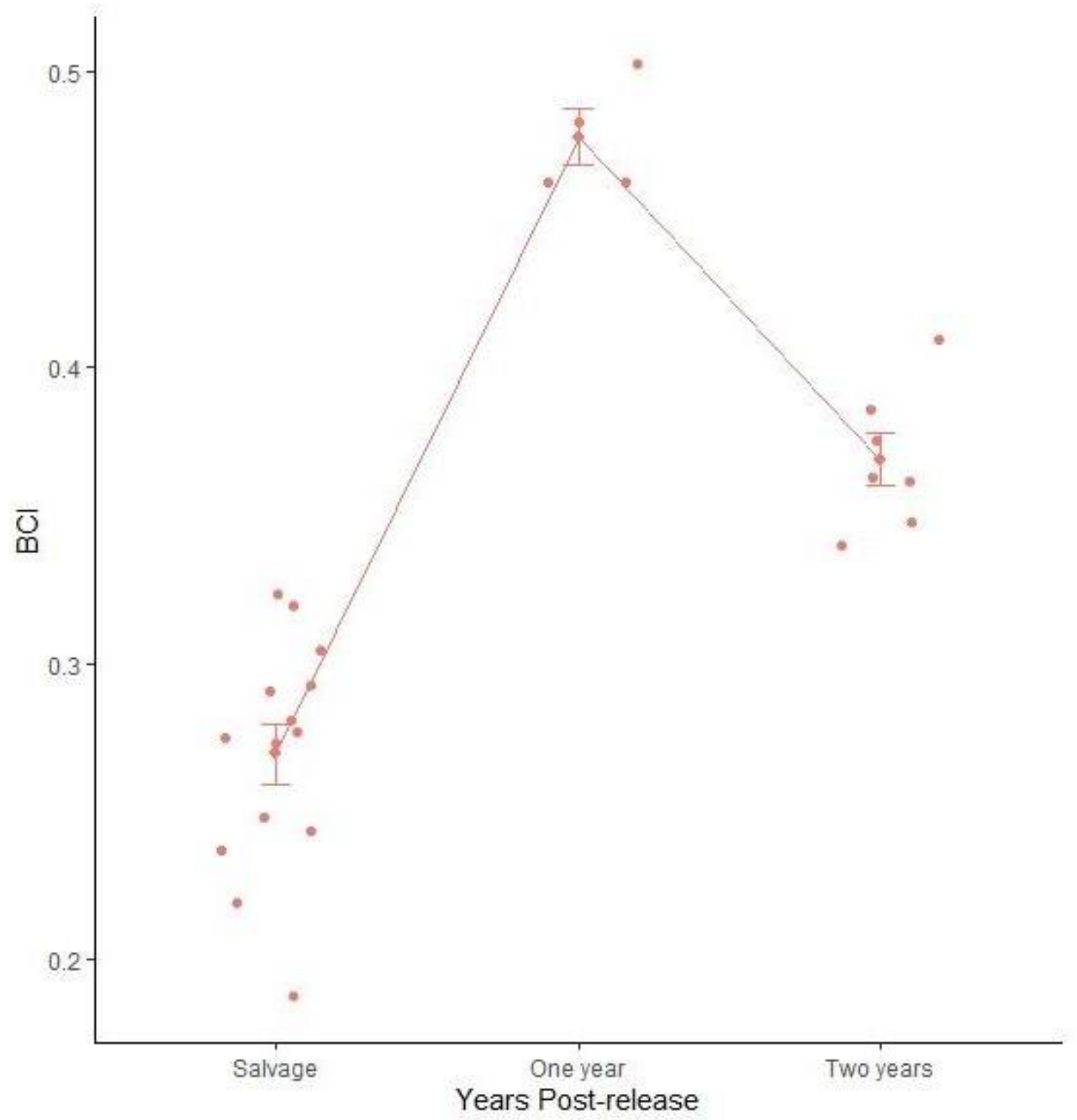

Type

Translocated

Figure 2.6.: General trend for mean BCI of translocated individuals which were recaptured inpost-release monitoring and met $\mathrm{BCI}$ analysis inclusion criteria. 


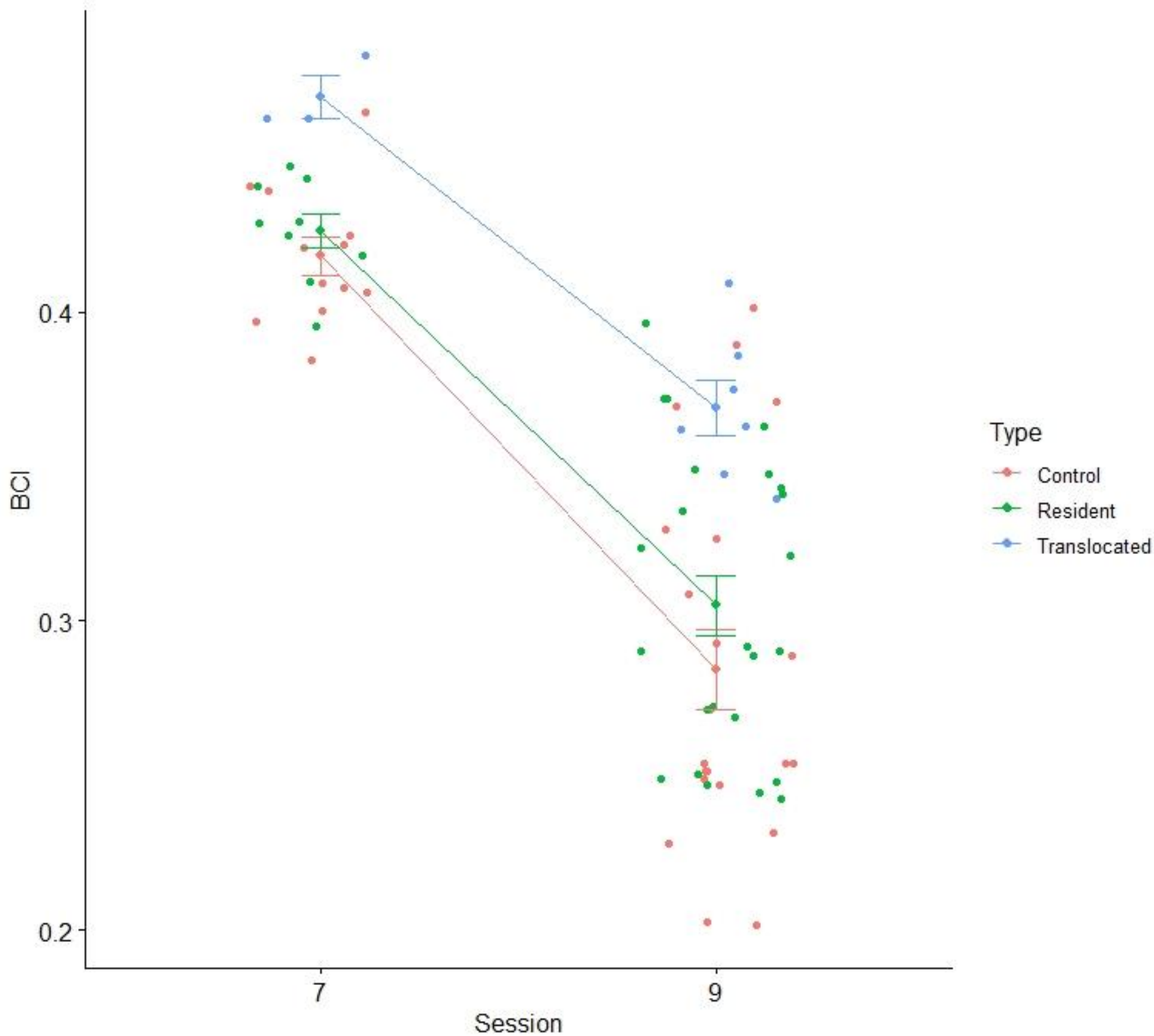

Figure 2.7.: Relationships between session and BCI (for sessions which monitored all sites during late summer) and group type and BCI. All groups declined in BCI between session 7 (January 2020) and session 9 (January 2021) at similar rates. 
With the exception of pregnant females and juveniles, all individuals captured in sessions 7 and 9 were included in analysis $(n=91)$. Duplicate observations of the same individual were identified using temporary identification and excluded from analysis. Results from a two-way ANOVA showed BCI was significantly lower during session 9 than session 7 $\left(\mathrm{F}_{(1,72)}=128.29, \mathrm{p}<0.001\right)$. Using Wilcoxon pairwise tests, session was found to be associated with mean BCI of the translocated group between sessions 5 and 7 (BCI increased, $\mathrm{p}<0.001$ ), 5 and 9 (overall increased, $\mathrm{p}<0.001$ ), and between sessions 7 and 9 (BCI declined, $\mathrm{p}<0.001$, Figure 2.6.). Despite a decline in BCI between sessions 7 and 9 (one- and two-year post-release intervals), overall condition was still higher at session 9 than at salvage. Mean BCI was significantly lower in session 9 compared with session 7 for the resident and control groups as well ( $\mathrm{p}<0.001$ for both groups, Figure 2.7.).

BCI was significantly different between group types (translocated, resident, or control; $\left.\mathrm{F}_{(2,72)}=10.97, \mathrm{p}<0.001\right)$. A Tukey post-hoc test showed significant differences between mean BCI for the translocated individual group and resident individual group $(\mathrm{p}<0.001)$, and translocated and control group ( $\mathrm{p}<0.001$; Table 2.3., Figure 2.7.). No significant difference was found between the mean BCI of the resident and control groups $(\mathrm{p}=0.13)$. The results showed the control group experienced a similar rate of decrease in body condition score between January 2020 and January 2021 as resident and translocated groups (Figure 2.7.). When all control site monitoring sessions are plotted, this decreasing trend fits into an overall declining body condition trend at control sites from 2017 - 2021.

\subsubsection{Evidence of reproduction}

Recapture of pregnant translocated females was low at both receptor sites over two years of post-release monitoring: $3 / 5$ recaptured translocated females were pregnant at site $\mathrm{A}$ and $6 / 18$ at site B. Twenty-eight juveniles were observed across sessions 5.5-9, five of which were 
translocated individuals recaptured in sessions 5.5-6 (one at receptor site A and four at receptor site B).

\subsection{Discussion}

\subsubsection{Main findings}

This study is one of the first to follow a mitigation translocation of skinks, report on the recapture rate and body condition changes over two-years of post-release monitoring, and to evaluate the use of receptor sites with resident skink populations. While the mitigation translocation rescued 389 skinks from the development site, only $11.1 \%$ were recaptured. Threequarters of translocated individuals were found within 10 metres of their release points; however, some individuals travelled up to 90 metres from their release point, implying dispersal outside the trapping range is feasible, particularly with time. Mean BCI of translocated individuals was significantly higher at one- and two-years post-release compared to salvage BCI despite a decline in mean BCI between years one and two post-release. Mean BCI was consistently higher in translocated skinks than resident or control skinks. Translocated, resident, and control body conditions declined at similar rates between January 2020 and 2021, likely representing a seasonal impact rather than a direct result of the translocation. Evidence of reproduction was supported by the observation of pregnancy in recaptured females post-translocation.

Mitigation translocations do not share the same goal of long-term individual survival at receptor sites (Germano et al., 2015; Sullivan et al., 2015), producing a self-sustaining population, or net conservation benefit like other translocation types (Department of Conservation Lizard Technical Advisory Group, 2018; Seddon et al., 2007). As there are no predefined thresholds or timeframes to accomplish a recapture rate goal or assess body changes, 
the translocation can only be assessed on its goal of rescuing skinks from immediate harm and meeting legal obligations set out by the territorial authority. Therefore, the translocation was successful in meeting its legal obligation of mitigating damages to skinks at the Cobham Drive site using translocation and serving as a research project to evaluate the use of sites with known skink presence. Recapture rates, body condition changes, and evidence of reproduction suggest short-term success of this mitigation translocation when compared with mitigation translocations of herpetofauna in other countries (1.6\%, Nash et al., 2020) and in New Zealand ( $0 \%$ for translocations of few individuals, Lennon, 2019; 4.8\%, Trent Bell pers. comm.). However, the net conservation benefit in uncertain and recapture rates fall below reported recapture rates of conservation translocations of New Zealand herpetofauna (57\%, Nelson et al., 2002; 37-100\%, van Winkel, 2008; 45\%, van Winkel and Habgood; 2009).

\subsubsection{Stage 1 success}

When compared to control sites in Wellington City, the recapture rates of translocated skinks at receptor sites fall below the average recapture rate for four monitoring sessions $(9 \%$ and $11.8 \%$ for receptor sites $\mathrm{A}$ and $\mathrm{B}$, respectively, compared to an average of $14.5 \%$ across all catching control sites). However, it is important to note that these recapture rates were calculated using different sessions; control recapture rates were calculated from sessions over 2017 - 2019 summers, when permanent identification allowed for reliable recapture of individuals whereas recapture rates of translocated and resident individuals occurred over the late post-release monitoring sessions, 2019 - 2021. Time and seasonality effects on recapture rates of translocated skinks should therefore be further studied.

The recapture rate of founders was higher at receptor sites of this translocation than averages reported by national and global reports of failed or uncertain outcomes for mitigation translocations of herpetofauna (Edgar et al., 2005; Germano et al., 2015; Sullivan et al., 2015; 
Bradley et al., 2020; Nash et al., 2020). The recapture rates for this translocation are also higher than some recent mitigation translocations of skinks in the Wellington region which report $0-$ 5\% recapture rates of founders (Trent Bell and Richard Romijn pers. comm.; Lennon, 2019). However, recapture rates of $9-11 \%$ are not considered successful in comparison to recapture rates of conservation translocations in New Zealand. Some conservation translocations of herpetofauna report 45\% recapture rates (van Winkel \& Habgood, 2009) and 100\% survival rates on predator-free offshore islands (van Winkel, 2008).

The overall body condition trend from salvage to one- and two-years post-release was positive for assessed translocated individuals. However, only 22 recaptured translocated individuals met body condition analysis criteria. While the overall trend showed an increase in mean BCI for translocated individuals, it represents a small proportion of the translocated group and serves to support the evidence of stage 1 success but cannot be used independently to classify success of this translocation. Body condition improving for translocated individuals could be a sign of competitive release at the receptor sites, despite receptor site $\mathrm{B}$ having a resident population.

It was not possible to assess whether the release of translocated individuals has caused declining body conditions of resident individuals as the resident population was not surveyed prior to the translocation. This trend seems to closely match the declining trend of individuals at control sites. One possible explanation is that body conditions will fluctuate as a site reaches carrying capacity and the sudden influx of almost 300 individuals could be increasing competition at the receptor site (Fitzgerald et al., 2015; Bradley et al., 2020). However, as the rate of decline between translocated, resident, and control groups is similar, the change is most likely attributed to environmental conditions which may have affected the region. Further monitoring is required to understand the long-term trends of body condition at receptor sites. 


\subsubsection{Evidence for long-term success}

There is evidence of reproduction in translocated groups at both sites; $60 \%$ of recaptured translocated females were pregnant at site $\mathrm{A}$ and $50 \%$ at site $\mathrm{B}$. However, modifications are needed to apply current short-term success criteria to mitigation translocations which use receptor sites with unstudied variables. It is now common practice to relocate skinks to sites with a resident population (Romijn \& Hartley, 2016; Wildland Consultants, 2018, 2019c; Lennon, 2019). However, integration of translocated and resident groups means stage 2 success cannot be accurately assessed without genetic analysis, which has been used to assess reproduction of founders and integration of translocated and resident populations in translocations of desert tortoises (Mulder et al., 2017). The Cobham Drive translocation did not collect genetic samples; therefore, the only way to determine evidence of reproduction for the translocated group from receptor site B (resident population present) is to report pregnant translocated females. This method also means there is no information on the survival of offspring of translocated individuals or whether the sire is a translocated or resident male.

\subsubsection{Limitations}

Factors which may have effected recapture rates, but which could not be isolated in this study, include individual dispersal from release point (to unmonitored parts of the site), increased vulnerability to predation, competition against a better-established resident population, disease related mortality, or dispersal out of the site entirely. Dispersal is a well-known phenomenon in other translocation studies of herpetofauna (Ebrahimi \& Bull, 2012, 2013; Le Gouar, 2012; Nafus et al., 2017, Nash \& Griffiths, 2018) and likely contributed to low recapture rates at the receptor sites. This study did not monitor beyond release points at receptor sites, but recorded skinks traveling approximately 90 metres within the receptor site post-release.

In this study, 8 individuals were removed from recapture and body condition analyses 
because they either had toe loss which made toe codes unreliable or codes which could not be matched to the toe codes used at the salvage event. This number increased over time as individuals aged and were more likely to experience natural toe loss.

\subsubsection{Recommendations}

With mitigation translocations becoming more relied upon to rescue native fauna from developing urban areas, it is essential that we fully understand outcomes of current mitigation translocation protocols and their effect on individual survivability and long-term establishment at receptor sites. The lessons we learn from inconclusive results and failures are the key to creating "best practice" protocols and overall success for individuals and groups.

Other options should be considered before translocations are used to mitigate effects on wildlife due to development. However, if mitigation translocations are the only option, they should be done with guidelines and recommendations employed by conservation translocations (i.e. those provided by IUCN and national authorities such as DOC). Main recommendations from this chapter reiterate those made by previous reviews of translocations (Dodd \& Seigel, 1991; Germano \& Bishop, 2009; Miller et al., 2014; Germano et al. 2015) and include: 1. Establish goals and timeframes, 2. Conduct long-term monitoring post-translocation, 3. Use of permanent identification for translocated individuals, 4. Ensure enforcement of resource consent obligations and reporting requirements, 5. Greater investment in receptor site preparation, and 6. Surveying receptor sites for resident populations.

1. Objective goals to evaluate translocation success, such as recapture rate and individual growth, must be established prior to the salvage event, such as those recommended by IUCN and New Zealand Department of Conservation guidelines (IUCN/SSC, 2013; Department of Conservation Lizard Technical Advisory Group, 2018; 2019). Furthermore, an exit strategy must be prepared for use in the event that the salvage 
results in low catchor presence of endangered species (Lennon, 2019).

Along with this, long-term monitoring is essential to better understand how recapture rates and body conditions of translocated individuals change over time from release. Long-term monitoring can inform site and population management strategies as well as future mitigation translocation protocols. It can be very difficult to establish lizard absence without extensive monitoring of a site (Hare, 2012; Lettink et al., 2011). For instance, receptor site A in this study was monitored for 2 years (1000 trap days) without finding evidence of a resident population inhabiting the site (Woolley, 2020). Furthermore, a majority of recaptured translocated individuals were recaptured in postrelease monitoring session 5.5 but some individuals were not recaptured until 2 years post-release. For northern grass skinks, three years of monitoring covers the entire or a majority of the expected lifespan (3-5 years; van Winkel et al., 2018); for other New Zealand lizards with long lifespans, the requirement for long-term monitoring could be 10+ years (Romijn \& Hartley, 2016).

2. Use of permanent identifiers (particularly in the form of toe codes) is not always possible as it requires training and iwi permission, but is highly recommended to accurately report short-term success stages such as recapture rates and individual growth of translocated lizards. Some toe codes could be reliably read 2 years post- application and provided an essential piece to understanding the survival and growth of founders, particularly at receptor site B which already hosted an un-surveyed population of the same species.

3. Several studies have shown the lack of reporting of mitigation translocations, particularly those with uncertain or poor results. Isolating factors which may have led to these results is an essential step to improving protocols and outcomes, as well as for reconsidering mitigation translocations as the best solution to mitigate human impacts 
on wildlife. Further obligations sometimes include biodiversity offsetting or receptor site preparation, but compliance to these obligations is difficult to assess and they can be relatively unenforced (Brown et al., 2014; Brown, 2017; Lennon, 2019; Maseyk et al., 2018). Further points regarding reporting include uncertainty regarding calculation of recapture rates, as it is important that they reflect the number of individuals recaptured from the translocation rather than the number of individuals observed. In the case of both receptor sites, using a count of observations (similar to CPUE) to report recapture rates resulted in 5-5.5\% inflation, which can result in misleading reporting, particularly in the case of meeting success criteria goals.

4. Optimization of receptor sites is essential to ensure survivability and long-term success of translocated individuals and groups. Receptor site preparation is an important principle as set by DOC (Department of Conservation Lizard Technical Advisory Group, 2018; 2019) and the IUCN (Batson et al., 2015; IUCN/SSC, 2013). These principles include targeting the agent of decline; in the case of mitigation translocations this is the development, however, introduced predators are renowned as the biggest threat to New Zealand skinks (Whitaker, 1973; Towns, 1991; Reardon et al., 2012). Management of predators should begin at receptor sites prior to release to effectively reduce predator presence at receptor sites (Parkes et al., 2014; Pech \& Maitland, 2016) and optimize success of translocated lizards (Norbury et al., 2014; Wilson et al., 2017). Principles also include selection of appropriate habitat and/or habitat enhancement or resource supplementation (Department of Conservation Technical Advisory Group, 2018; 2019). Habitat enhancement often includes vegetation projects which may benefit species (such as those in Herbert, 2020), but recent studies investigated the use of rock piles to benefit lizards and exclude predators (Lennon, 2019). Enhancements such as soft-release pens (Ebrahimi \& Bull, 2013; Knox \& Monks, 2014; DeGregorio 
et al., 2020) or predator-proof fences (Burns et al., 2012; Nelson et al., 2016; Wilson et al., 2017) should also be considered, particularly for translocations to mainland sites (which often have a suite of predators, Romijn \& Hartley, 2016; Lennon, 2019). Habitat enhancement can also include food and resource supplementation which can reduce dispersal of individuals and/or improve survival (Ebrahimi \& Bull, 2012).

5. An evaluation of resident lizard populations which may be inhabiting the receptor site is also necessary (a recommendation made in one of the first reviews of translocations of herpetofauna - Dodd \& Seigel, 1991 and repeated as a key principle in Department of Conservation Lizard Technical Advisory Group, 2019). The lack of baseline monitoring of resident skinks at receptor site B made it impossible to assess the effect the translocated group may have had on the resident population.

While the translocation studied in this project rescued nearly 400 skinks from immediate danger, the fate of a majority of translocated skinks (89\%) and extent of cumulative biodiversity loss (impact on habitat and species) is unclear. This mitigation translocation is an example of a failed translocation at this point, even with the inclusion of some recommended practices (permanent identification, translocated group dynamics (M:F:J ratios), and survey of receptor site). This result supports the statement that mitigation translocations of herpetofauna do not provide a conservation benefit (Germano et al., 2015; Lennon, 2019; Bradley et al., 2020) and reiterates the call for further research before mitigation translocations continue to be used as a go-to strategy for mitigating the effects of development on herpetofauna globally and in New Zealand (Germano et al., 2015; Sullivan et al., 2015). 


\section{Chapter 3}

Receptor site preparedness for mitigation translocations of lizards

\subsection{Introduction}

\subsubsection{Protected areas as translocation receptor sites}

Protected areas, clearly defined spaces with legal management which achieve long-term conservation of nature and cultural values, such as national and regional parks, safeguard important wildlife and their habitats, and offer spaces to connect the public to nature (Dudley \& Stolton, 2008). While the management and goals of national parks, regional parks, and reserves differ, they are generally classified as protected areas and have goals to preserve or restore habitat and conserve native biodiversity (IUCN, 2013). Methods for legally protecting wildlife and restrictions on human activity vary among countries, but generally include laws which protect the lives and habitat of wildlife from being disturbed by human activities 
(Endangered Species Act of 1973 (USA), Wildlife \& Countryside Act 1981 (UK), Animal Welfare Act 1992 (AUS), Conservation of Habitats and Species Regulations 2010 (UK), Nature Conservation Act 2014 (AUS)). Many parks and protected areas are in the process of being restored and investment in biodiversity in parks is increasing. Protected areas are particularly used for habitat restoration or enhancement research to maintain their protected status and develop methodology to restore (Newmark et al., 2017; Markle et al., 2018) and protect other altered areas (IUCN, 2012; Meserve \& Kelt, 2016; Schoukens, 2017). Some high profile examples of protected areas used to benefit wildlife species include grey wolf reintroduction to Yellowstone National Park (Fritts et al., 1997), osprey (Monti et al., 2014) and badgers restored into protected natural areas of Italy (Balestrieri et al., 2006), and using protected areas to mitigate human-wildlife conflict by relocating "nuisance wildlife" such as bears (Spencer et al., 2007) and venomous snakes (Brown et al., 2009).

New Zealand legislation protects national and regional parks (Resource Management Act, 1991; Regional Policy Statement for the Wellington Region, 2013). National parks are managed by the Department of Conservation (DOC) and primarily focus on the preservation of natural areas and wildlife, with strict rules for human activities within parks (e.g. camping, hiking, disturbing biodiversity; National Parks Act 1980). Regional parks and land reserves are often smaller than national parks and managed by regional councils, often in collaboration with iwi, district and city councils, and community groups. Regional parks protect natural areas and offer spaces for recreational and cultural activities to the public, including biodiversity restoration projects (such as investigating current populations and reintroducing/reinforcing native species; EcoGecko Consultants, 2018).

\subsubsection{Mitigation translocations of New Zealand herpetofauna}

As part of restoration efforts, these sites sometimes receive translocations. Historically, a majority of conservation and research-focused translocations in New Zealand have used 
"best-practice" standards in the selection and preparation of receptor sites (Sherley et al., 2010; Romijn \& Hartley, 2016), where targeting the agent of decline and provision of habitat and resources are important, for example, predator-free offshore islands or mainland sanctuaries (Monks et al., 2014; Nelson et al., 2016). Irrespective of land protection status, New Zealand wildlife and their habitats are protected by law (Wildlife Act, 1953; Conservation Act, 1987; Resource Management Act, 1991 (RMA)).

More recently, movement of fauna has become driven by major alteration of habitat. Mitigation translocations, the intentional relocation of wildlife to mitigate damages to wildlife and their habitats due to human activities (Germano et al., 2015). Mitigation translocations often have uncertain outcomes or result in failure, particularly for herpetofauna (Miller et al., 2014; Germano et al., 2015). Whereas conservation and research translocations are known to utilise high standards of practice, mitigation translocations are not known to use many of the criteria deemed important to ensuring survival of individuals and success of populations, including relocating individuals to locations without habitat protection (Germano et al., 2015; Sullivan et al., 2015; Romijn \& Hartley, 2016).

The practices used in mitigation translocations are reactive by nature - resulting in short timeframes and restricted budgets for ecologists and territorial authorities to conduct biological surveys, receive resource consent permits (requirement of the RMA; Brown et al., 2014; Miskelly, 2014), develop lizard management plans, prepare receptor sites, and translocate lizards. In response to these situations, DOC has developed a document detailing nine principles for lizard salvage, recommending the assessment of lizard species values and site significance, thorough assessment of actual and potential damages caused by development (such as biological surveys), the alternatives to translocation (these exist but are not commonly used), additional considerations for threatened species, use of best-practice methodology at salvage and receptor sites, post-release monitoring, reporting, and lastly, 
contingency actions in the event of failure (Department of Conservation Lizard Technical Advisory Group, 2019). Wildland Consultants, Ltd., an ecological consultancy that often undertakes mitigation translocations also prepared a guidance document detailing the current practices, challenges, and recommendations regarding salvage protocols, post-release monitoring, reporting, and contingency plans (Wildland Consultants, Ltd., 2019c). The two documents agree that post-release monitoring goals and reporting obligations need to be clearly defined, that provision of habitat enhancement and long-term, intensive predator control at receptor sites may be required, and preparation of contingency plans are important to ensure no net loss of lizard populations.

Data on mitigation translocations are not currently compiled in one central location. The Department of Conservation manages two databases which together contain information about routine herpetofauna monitoring and translocation data for all fauna - the Amphibian and Reptile Distribution Scheme (ARDS, also known generally as "the BioWeb Herpetofauna Database") and the DOC internal-only Translocation Database. However, in addition, reports from contracted ecologists are made for the territorial authority. While these reports might contain details regarding timelines, translocated group sizes, habitat assessments, site characteristics, and post-release monitoring results, logistical information such as salvage timeframe, salvage and receptor site characteristics and site improvements are separately available by link in the Translocation Database, using the DOC intranet (Lynn Adams pers. comm.). A 1998 summary of the translocation database reported 10 translocations across 5 Oligosoma species from 1988 to 1993 (Department of Conservation, 1999). There was a recommendation in this summary for suspended use of the database until it could be further developed to store more information about translocations and be better utilised at the national scale. It is uncertain whether this recommendation was taken or to what extent use of the database may have been suspended. Along with difficulty isolating cases and details of 
mitigation translocations in the Translocation Database and disparate reports, it is likely that many mitigation translocations have not been reported to the Translocation or BioWeb HerpetofaunaDatabases.

\subsubsection{Greater Wellington Regional Council Research Project}

Wellington is a unique city, renowned for its dedication to green spaces within the urban centre and proximity to regional parks, less than $15 \mathrm{~km}$ from the city centre. There are 16 regional parks spanning over 33,000 hectares (ha) in Wellington region alone. These parks vary in land type and level of preservation, from coastal dunes (Queen Elizabeth Park, Oruapouanui) to wetlands (Wairarapa Moana wetlands) and mountainous native forest (Belmont and Kaitoke Regional Parks). Regional parks and green spaces in Wellington have been used in an ad hoc manner as receptor sites for lizards translocated from development sites (Department of Conservation Technical Advisory Group, 2019; Wildland Consultants, Ltd.; 2019c). There is a strong motivation to be more prepared for and to demand better outcomes from mitigation translocations.

This project was conducted in collaboration with Greater Wellington Regional Council (GWRC) and DOC, contributing to a research experiment which will test the success of mitigation translocations of herpetofauna when "best-practice" protocols are used (IUCN/SSC, 2013; Department ofConservation Lizard Technical Advisory Group, 2018; 2019). The driver to conduct this research stemmed from a mitigation translocation in 2018 which resulted in less-than-favourable outcomes (Richard Romijn pers. comm.). Over 2,000 northern grass skinks (Oligosoma polychroma) were salvaged, kept in captivity over winter which resulted in high individual loss (estimated at 500 skinks) and reported a low recapture rate in post-releaseshort-term monitoring ( $4.8 \%$ in one session of post-release monitoring; Trent Bell and Richard Romijn pers. comm.). Like a majority of mitigation translocations, monitoring did not continue beyond the first session (Trent Bell pers. comm.; Romijn \& 
Hartley, 2016).

The GWRC biodiversity team developed this research project to take a proactive approach to mitigation translocations of local lizards by preparing regional parks as receptor sites, aiming to evaluate and approve multiple sites across many parks using "best-practice" selection criteria. The plan included baseline monitoring to establish presence/absence data for resident lizard populations, habitat enhancement, and predator control for each site before a translocation occurs.

\subsubsection{Aims}

I contributed to the GWRC project by assisting to initiate a proactive approach to mitigation translocations by integrating "best practice" protocols. I aimed to select and conduct preliminary lizard surveys at six potential receptor sites for northern grass skinks within three Wellington regional parks or reserves, and prepare recommendations for criteria to select future receptor sites. Recognising there is a need for a mitigation translocation specific database (or method to identify mitigation translocations in the general DOC Translocation Database), I also aimed to propose elements of a record-keeping geodatabase to detail the components of the translocation process and receptor site specifics. Lastly, I aimed to develop a framework for receptor site preparation, integrating the recommended criteria and using the geodatabase format, for the adaptive management of receptor sites pre- and posttranslocation.

\subsection{Methodology}

\subsubsection{Study Sites}

GWRC recommended two regional parks and one land reserve for assessment to be receptor sites for future mitigation translocations of northern grass skinks due to the land tenure and protected statuses of the parks and reserve (owned by DOC), potential for restoration or 
restoration projects underway, and/or community involvement. The parks and reserve selected were Belmont Regional Park (BEL), Queen Elizabeth Regional Park (QEP), and Whareroa Recreation Reserve (henceforth known as Whareroa Farm, WF). Belmont Regional Park is situated north of Wellington city and separated from Wellington harbour by a small neighbourhood and the motorway. The largest park in the region, it is roughly 3480 hectares (ha) in size, with a large farm lease in the northern part of the park. Te Ati Awa are guardians of this park and Lower Hutt City Council is the territorial authority, under governance of GWRC. There has not previously been lizard monitoring at this park and predator monitoring has been conducted in parts of the park to inform future predator control.

Queen Elizabeth Regional Park preserves the last natural dune landscape on the Kapiti coast in Wellington. The park is approximately 650 hectares between neighbourhoods, the coastline, and the motorway (Figure 3.1.A.). The park is managed by GWRC in collaboration with the Friends of Queen Elizabeth Park community group and Te Atiawa ki Whakarongontai are guardians of the land. The community group provides predator control and conduct revegetation projects, planting native shrubs (divaricating shrubs, Coprosma spp.) and flax (Phormium tenax, harakeke). A majority of the historical land use change can be attributed to clearing for agricultural purposes. The park still hosts a large farm lease along the eastern side (Figure 3.1.C.), although this lease has not been renewed for the future. Along with coastal dunes, mature native bush exists at the southern end and the community group previously planted native flax and shrubbery in Site D (Figure 3.1.C.). The community group has invested in lizard monitoring within the park, resulting in evidence of low-moderate numbers of northern grass skinks near the neighbourhoods at the North and South entrances of the park (EcoGecko Consultants, 2018; Figure 3.1.A.). There is interest in surveying further into the park and potentially assisting northern grass skinks in recolonizing within the park as it is restored. 
Whareroa Farm is owned and operated by the Department of Conservation along with the Whareroa Guardians community group and Ngāti Toa. The reserve is being restored with revegetation projects and has remnants of native forest which are protected or under review to become Significant Natural Areas in the region (Dudley \& Stolton, 2008; Greater Wellington Regional Council, 2016). Whareroa Farm provides opportunity for collaboration with Whareroa Guardians, who began lizard monitoring at a cultural site, The Cairn, in 2018. The Cairn is a large structure made of rocks at the top of a small hill on the farms with three lizard monitoring grids surrounding it for a total of 150 traps (pitfall traps with artificial cover objects (ACOs) on top, Figure 3.3.). The Cairn was revegetated with tussock and divaricating shrubs before previous lizard monitoring and is still regularly maintained (weeding and reinforcementsto replace failed plantings). Lizards were not observed at the Cairn, but low numbers of northern grass skinks were reported in studies conducted in forest remnant sites (EcoGecko Consultants, 2018).

\subsubsection{Receptor Site Selection Criteria}

General practice in mitigation translocations is to select receptor sites which provide habitat of the translocated species (using aerial imagery such as Google Maps or ArcGIS), historical records (BioWeb Herpetofauna Database or field guides), and working knowledge of appropriate sites within a reasonable distance of the salvage site (usually $5 \mathrm{~km}$ ). Potential receptor sites may or may not be visited prior to the release of translocated individuals. However, in this study, there was a two-step process including a desktop exercise and a site visit confirmation. The GWRC biodiversity team reviewed potential receptor sites within regional parks to receive northern grass skinks in a desktop exercise using ESRI software (ArcGIS New Zealand urban imagery base map and GWRC regional park layer, accessible online) and made preliminary site selections avoiding areas inside current farm lease boundaries or those with future plans for land use change. Aerial imagery shows general 
terrain and was used to conduct a preliminary review of the site's provision of northern grass skink habitat, as described in field guides (e.g. van Winkel et al., 2018). Recent field guides and reports on historical ranges of species were used to confirm that the proposed sites within regional parks were included in the historical range of northern grass skinks (Daugherty et al., 1994; van Winkel et al., 2018; Woolley et al., 2019). Prospective sites were drawn in as polygons on a base map layer in ArcGIS before site visits occurred. Attribute tables associated with each polygon contained minimal information, including site name and general habitat classification.

I conducted the second step in the selection process, site visits, to confirm the proposed sites were easily accessible (within typical 4-wheel drive capabilities), provided suitable northern grass skink habitat, had not recently experienced and were not scheduled to experience significant land use changes in the near future, and were approved by land managers and community groups to be altered in the future to accommodate monitoring and enhancement schemes. Other important considerations included daily weather conditions using a weather and habitat scoring system adapted from an ARDS template (Table 3.1.), particularly assessing the restriction to sunlight at sites which may be mostly bordered by forests (e.g. some parts of WF). Natural disaster risks such as flooding, coastal erosion (e.g. coastal QEP sites), or wildfire (e.g. BEL sites which are surrounded by dry grasses and gorse) were also discussed with land managers.

The information gathered in the desktop exercise and site visits resulted in the selection of two sites within each park, placed at over 250 metres apart, to ensure translocated lizard groups would remain separated (although see Chapter 2 for observed dispersal of 90 metres by one individual).Preference was given to sites which were north-facing or sheltered from southerly winds and those which received ample sunlight (minimal shading from neighbouring forests on hillsides instead of valleys; Figure 3.1.). 
Table 3.1.: Template for recording habitat quality and weather conditions at study sites. Modified from DOC ARDS card.

\begin{tabular}{|c|c|c|c|c|c|c|c|c|c|}
\hline \multicolumn{6}{|c|}{ Weather } & \multicolumn{2}{|r|}{ Major Habitat Types } & \multicolumn{2}{|r|}{ Micro-habitats } \\
\hline & Sunlight & & erature & Winc & & 1 & Beech Forest & $\mathrm{A}$ & Foliage \\
\hline 1 & Fine/Sunny & 1 & Hot & 1 & Calm & 2 & Podocarp Forest & B & Trunk \\
\hline 2 & Partly Cloudy & 2 & Warm & 2 & Light Breeze & 3 & Broadleaf Forest & $\mathrm{C}$ & Branches \\
\hline 3 & Overcast & 3 & Moderate & 3 & Mod Breeze & 4 & Exotic Forest & $\mathrm{D}$ & Under stones \\
\hline 4 & Showers & 4 & Cool & 4 & Gusty & 5 & Scrub & $\mathrm{E}$ & Underwood \\
\hline 5 & Rain & 5 & Cold & 5 & Strong Winds & 6 & Sub-alpine & $\mathrm{F}$ & Open ground \\
\hline 6 & Night & & & & & 7 & Alpine & G & Crevices \\
\hline 7 & $0-1 / 2$ Moonlit & & & & & 8 & Undeveloped tussock land & $\mathrm{H}$ & Ground Vegetation \\
\hline 8 & $1 / 2-1$ Moonlit & & & & & 9 & Developed farmland & I & Under Flax \\
\hline & & & & & & 10 & River Terrace & & \\
\hline & & & & & & 11 & Freshwater & & \\
\hline & & & & & & 12 & Wetland & & \\
\hline & & & & & & 13 & Coastal & & \\
\hline & & & & & & 14 & Scree & & \\
\hline & & & & & & 15 & Bare rocks & & \\
\hline & & & & & & 16 & Beach & & \\
\hline & & & & & & 17 & Urban & & \\
\hline
\end{tabular}




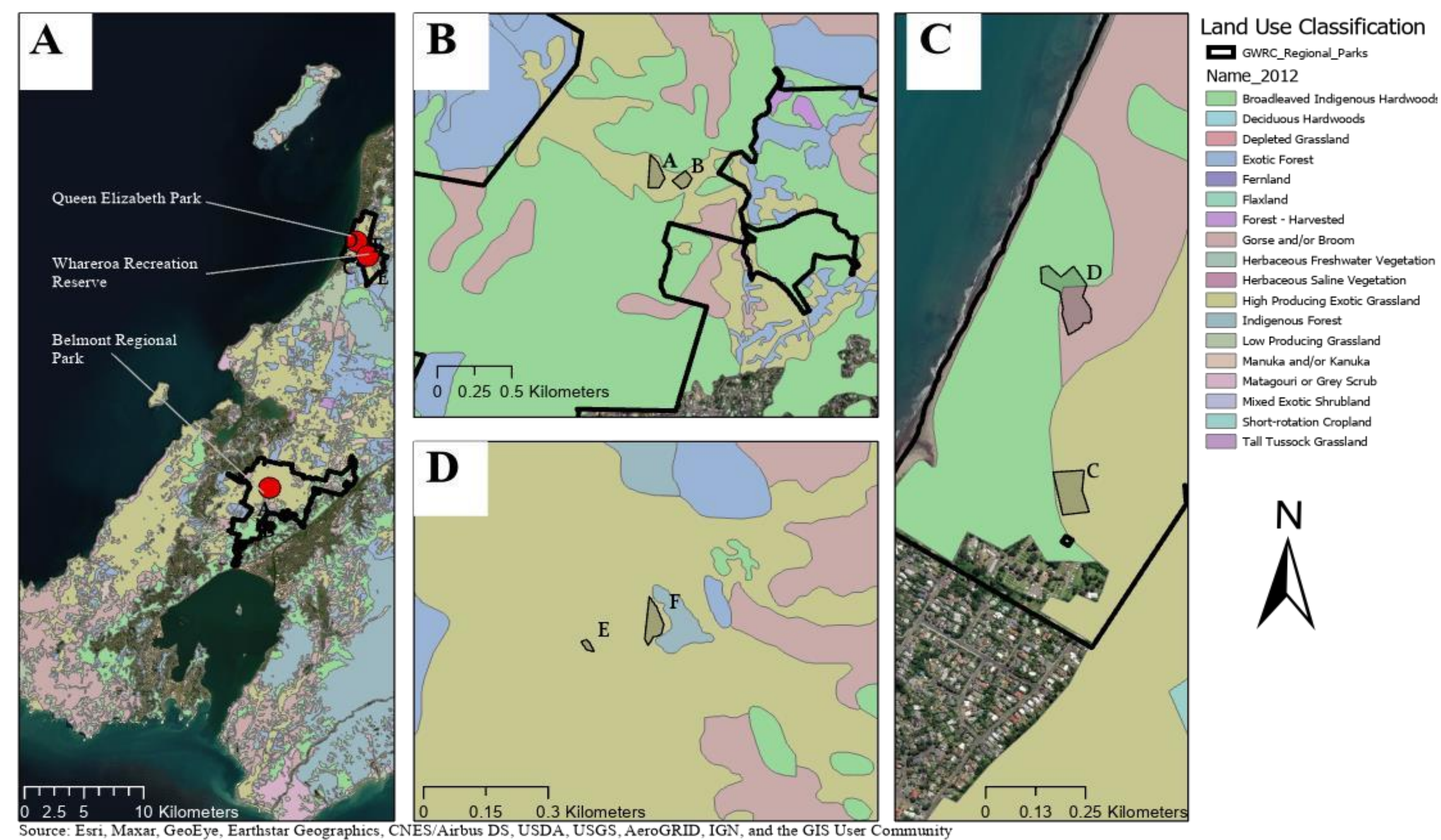

Figure 3.1.: A. shows a regional view of Wellington, New Zealand with LCDB v.4.1. (Deprecated) land cover classification layer applied. Locations (red points)and boundaries of regional parks/reserve selected for study are also shown. B. - D. focus on study site boundaries and land cover classifications in Belmont Regional Park, Queen Elizabeth Park, and Whareroa Recreation Reserve, respectively. 


\subsubsection{Baseline Lizard Surveys}

Generally, baseline monitoring for resident lizards at receptor sites is not conducted for mitigation translocations, in part due to their limited timeframes and outcome goals (meeting legal obligations to relocate lizards from immediate danger). If site visits and baseline monitoring do occur, they are often in the form of site walk-throughs and visual observation only. However, in this study, I conducted surveys using lizard capture and observation tools (Hare, 2012; Lettink et al., 2011). At five of the six sites, 20 pitfall traps were deployed in a random pattern (based on GPS points provided by ArcGIS 'Randomize Points' tool and modified to avoid damaging native flora, Figure 3.2.1. - 3.) This monitoring strategy was chosen to best survey the large sites (each somewhere between 0.33 - 1.3 hectares), and across variable habitat, targeting both open canopied grasses and neighbouring shrubbery which northern grass skinks are known to use (Herbert, 2020), and other native vegetation planted to restore the site (Queen Elizabeth Park \& Whareroa Farm Reserve). The goal was to evaluate presence of northern grass skinks, but this method allowed the possibility for analysis of population size and distribution if capture rates were high. At Whareroa site E, "the Cairn", previous monitoring was conducted by the Whareroa Guardians community group and this site was retained for comparison to receptor sites without background monitoring and habitat enhancement. Previous monitoring used pitfall traps in a grid formation $(4 \mathrm{x} 4)$ instead of the randomized strategy (trap composition was the same between the grid and random points, Figure 3.2.3.).

Pitfall traps were designed using 4-litre buckets, buried to fit snugly into the ground with artificial cover objects over top (ACOs, two $1 \mathrm{~m}^{2}$ sheets of roofing onduline with sticks or small rocks to create gaps suitable for lizards, approximately $10 \mathrm{~mm}$, Figure 3.3.). During monitoring, traps were opened with lids removed and resources provided to lizards inside including: a wet sponge, a fresh piece of pear, bundle of grass or leaf litter, and wire 
mesh cut to create a dome within the pitfall for added security from predators (Figure 3.3.; Hare, 2012; although see Woolley et al., 2021). Contents were restricted to the bottom $6 \mathrm{~cm}$ of the bucket and lizards could not escape.

Pitfall traps were monitored over 10 trapping days in January 2021 with all traps checked and re-baited daily in compliance with animal ethics approval. ACOs and pitfall traps were checked by hand and used large cardboard boxes to create barriers around traps to reduce escapes when ACOs were disturbed. Data collected from individuals documented date, time, park and trap number, ACO/pitfall capture, and morphometric data: snout-vent length (SVL, \pm $1 \mathrm{~mm}$ ), total length $( \pm 1 \mathrm{~mm})$, tail regeneration length (if applicable, $\pm 1 \mathrm{~mm})$, mass $( \pm 0.5 \mathrm{~g})$, species identification using photos for comparison with field guides, and sex (M/F). Juveniles were individuals with an SVL $<45 \mathrm{~mm}$. Individuals were given a temporary ID number written on the right side of the body, which generally last through the 10-day trapping session in dry weather conditions.

\section{Mapping}

I used ESRI Software ArcGIS Pro Version 3.2.4. for all mapping in this chapter including to view the original proposed sites and to randomise points at selected sites. 

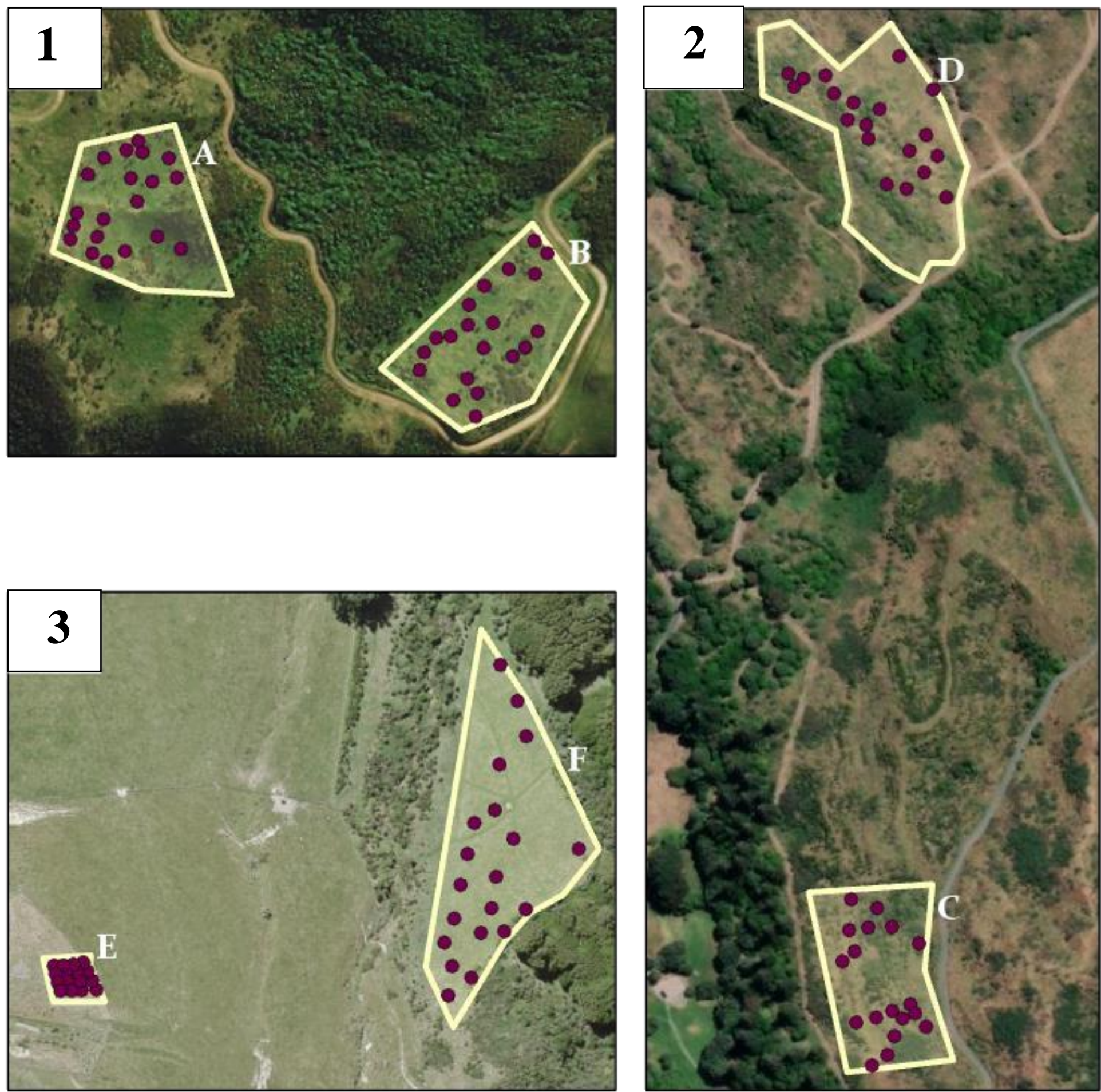

Source: Esri, Maxar, GeoEye, Earthstar Geographics, CNES/Airbus DS, USDA, USGS, AeroGRID, IGN, and the GIS User Community

Figure 3.2.1. - 3.: Pitfall placement of traps at each park/reserve. 1. - 3. Belmont Regional Park, Queen Elizabeth Park, and Whareroa Recreation Reserve sites, respectively. Arrangement was determined using ArcGIS Random Points Tool apart from Whareroa Site E "The Cairn", which had previous monitoring methods in place from community group lizard surveys. 

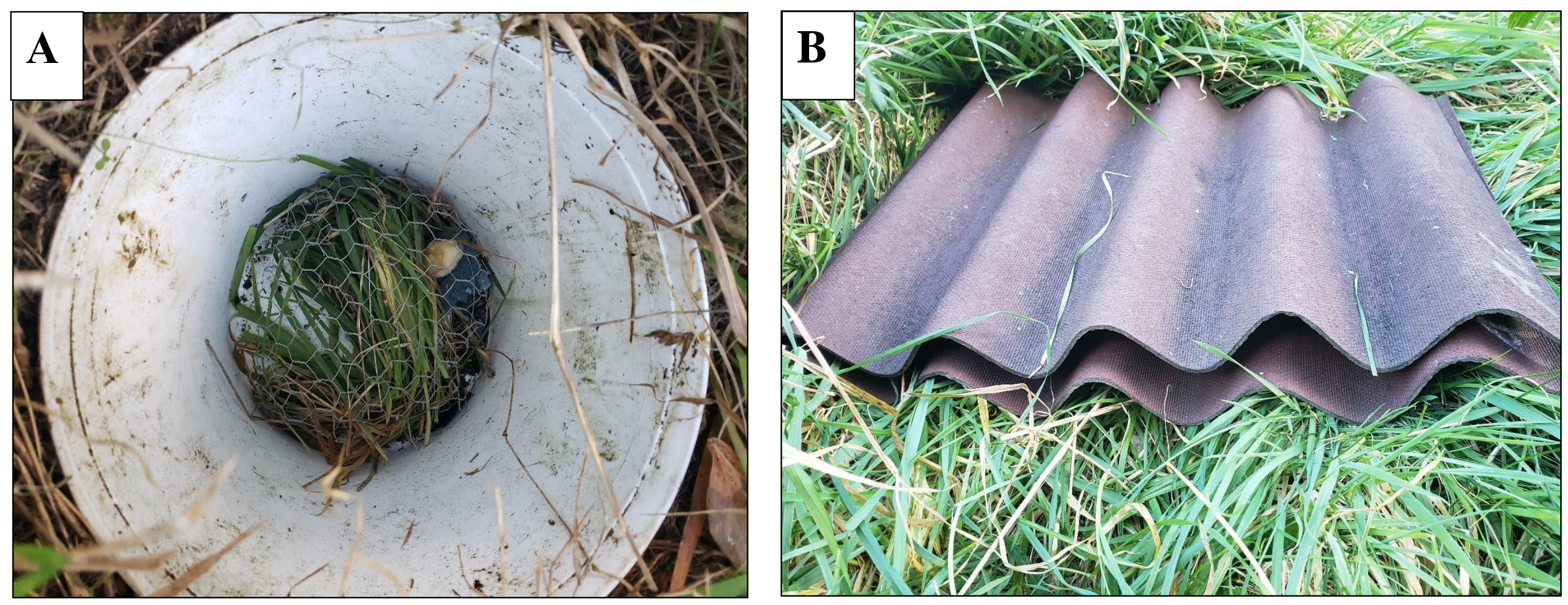

Figure 3.3.: A. Baited pitfall trap, 4-litre bucket with a bundle of grass to mimic local habitat, wet sponge (blue), piece of tinned pear, and wire mesh per recommendations for pitfall trap set-up by Hare (2012). B. Artificial cover object (ACO), two sheets of onduline (roofing material), separated by sticks or small rocks to create a gap for lizards to move between.

When traps are opened, the pitfall trap is prepared as above and the ACO covers the top of the pitfall trap. When closed, the contents of the pitfall trap are removed and the bucket is sealed with its lid; the ACO can remain on top to encourage lizard use throughout the year (Lettink \& Monks, 2016). 


\subsection{Results}

\subsubsection{Baseline survey results}

A total of 1,160 trapping days were conducted across all sites on sunny days with mild-warm temperatures for the pilot survey resulting in capture of only 4 individual northern grass skinks (O. polychroma); 1 at site $\mathrm{C}(\mathrm{QEP}), 2$ at site $\mathrm{E}(\mathrm{WF})$ and 1 at site $\mathrm{F}$ (WF). All individuals were adults of a healthy size with minimal tail loss or regeneration (Figure 3.4., Supplementary Table S3.1.).

Lizards were observed twice in the disturbed terrain from pitfall trap deployment in Belmont Regional Park site B but were not captured in pitfalls and therefore no data are available on these individuals, and I cannot be sure they represent more than one individual. Based on visual identification, these individuals were listed as $O$. polychroma as well. At WF site E "The Cairn”, previous lizard monitoring had been conducted by experienced community group members using the same methodology and there was no evidence of lizard presence at the site. I captured two individuals over 10 monitoring days at the Cairn, emphasizing the importance of multiple monitoring sessions to determine lizard presence. Although I can identify presence of $O$. polychroma at five of six sites, data were insufficient to carry out further analyses of abundance and distribution. Diversity information for lizards is limited, in part by the particular trapping technology deployed which predominantly assesses ground dwelling lizards. Reflections on the baseline survey include the need for more effort into surveys, for example, a second monitoring session at each site, and "walk throughs" to assess lizard presence with less site disturbance. 


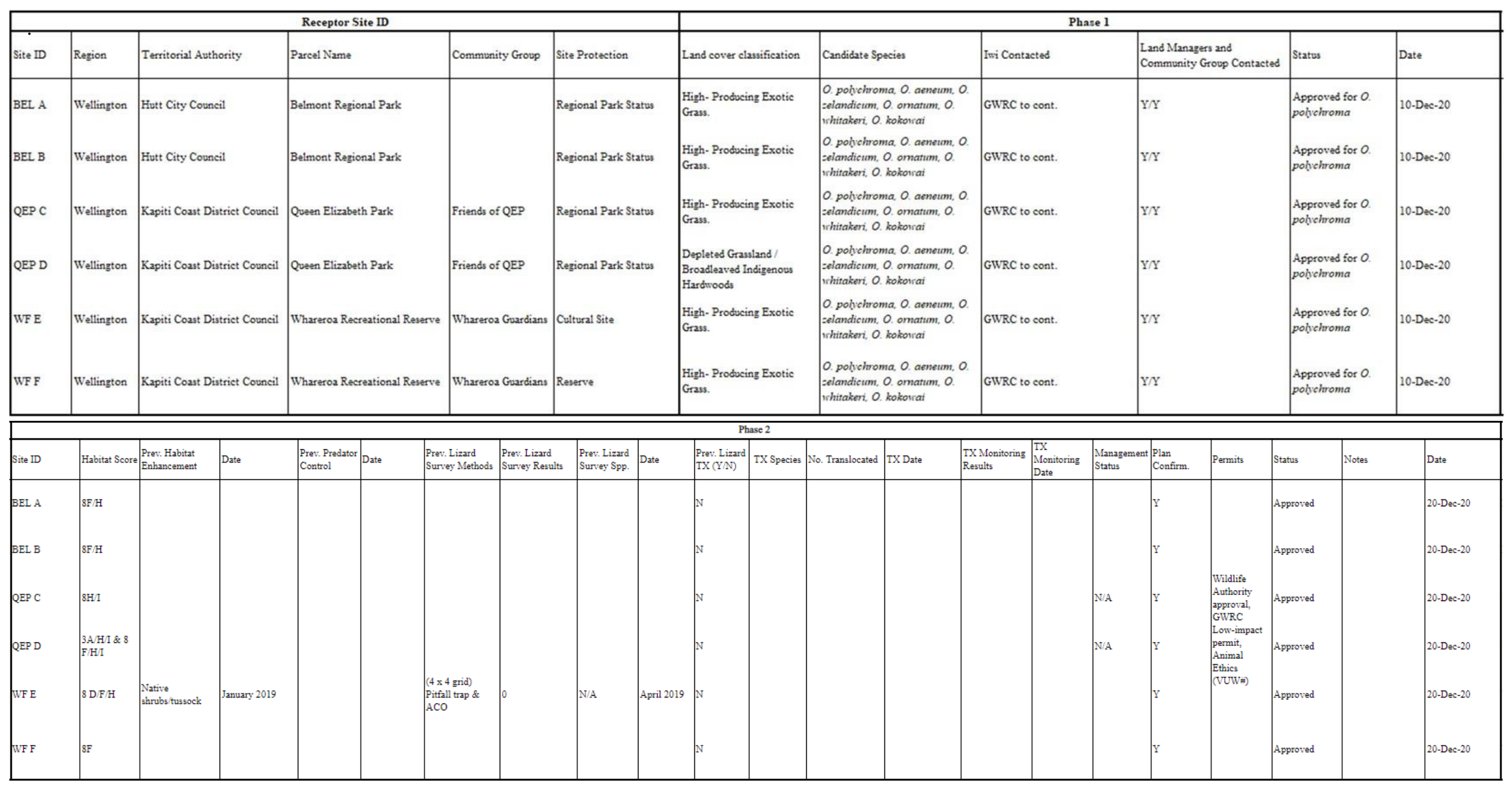

Figure 3.4. continues on next page. 


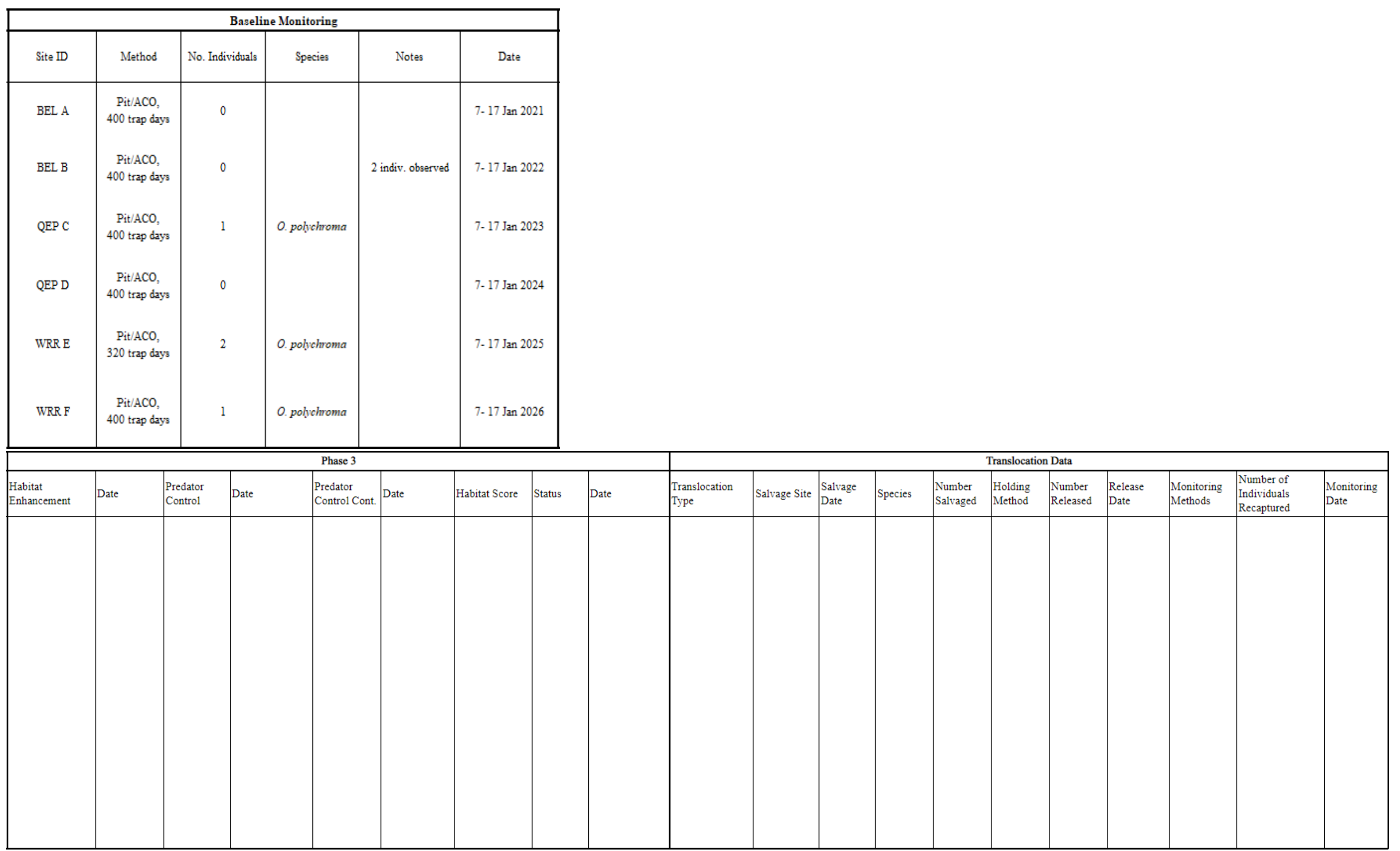

Figure 3.4.: Example of the recommended geodatabase attribute table. Criteria are separated by phase, each phase requests a status update and completion date with other requested information based on selection criteria. Information from GWRC research project pilot surveys are listed under "Baseline Monitoring", this section hasbeen isolated for easier readability. 


\subsubsection{Receptor site selection criteria}

Originally, four sites were proposed for each park from aerial photography and online mapping services. For Belmont Regional Park, two sites were excluded. One had been chemically burned to clear vegetation, had changed in land cover composition, and did not meet habitat protection or preservation standards. The second was difficult to access (blocked by farm gates), and any present lizard habitat was being overtaken by regenerating native bush.

In Queen Elizabeth Park, rejected sites included an area with strong evidence for a large population of northern grass skinks and a site where competing and non-aligned plans for management arose (to re-establish wetlands or within an active farm lease).

At Whareroa Recreation Reserve sites were rejected as they were too cold (settled in a valley between a tall hill and mature forest), were within active cattle pastures, or areas with high foot traffic and human disturbance. One of the sites selected at Whareroa arose only as part of site visits due to its potential and excellent comparative opportunity with the site E, "The Cairn".

At the selected sites, I found lizards at 5 of 6 sites, and all sites appeared to have suitable characteristics for lizards to occupy, reinforcing their selection as receptor sites. However, this effort goes no further in addressing the factors found wanting from mitigation translocation current practice. Therefore, having had an experience with receptor site selection and subsequently working at the sites, I developed criteria for receptor site selection further, and grouped them into 'phases' of organisation (Figures 3.4. and 3.5.). Phase 1 refers to aspects which can be addressed in-office by evaluating territorial authority boundaries, land cover classification, historical and current regional taxa information, and preliminary contact with respective iwi, land managers, and community groups (i.e. Criterion 1.4., Figure 3.5.). Phase 2 requires site visits to assess habitat (scored using a similar methodology to Table 3.1.), risk and 
further office-based research into previous studies, land management plans, and future site plans and opportunities (including the potential to install monitoring tools, conduct predator control, and enhance habitat). Phase 3 involves baseline lizard monitoring effort and followingup any other previously identified aspects, for example, habitat enhancement or predator control. Phases and criteria are organised in increasing levels of investment.

I propose the end of each phase includes a "Status" prompt, where sites can be "Approved", "Approved with changes", or "Rejected", allowing a history of site evaluation to be retained, and communication points for interested parties. Phases should not be interpreted as rigid, and instead aim to encourage proactive and adaptive management of receptor sites to optimize translocated lizard success (Figure 3.5.).

Figure 3.5. (next page): Framework integrating proposed receptor site selection criteria and geodatabase use, with arrows to represent workflow and adaptive management points. 


\section{$\underline{\text { Receptor Site Selection Framework }}$}

Phase 1: Background Information

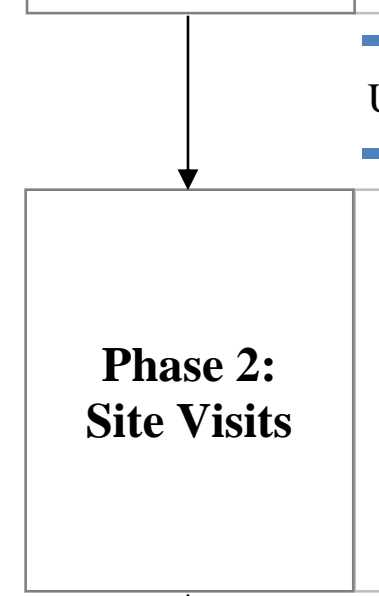

1.1. Identify regional parks or reserves which have protected status which might offer sites

1.2. Investigate lizard taxa historically and currently found in the region (particularly in urban areas, which are most likely to be translocated)

1.3. Use online resources, such as aerial photography via online map services or ArcGIS software to review land cover classifications and review land use within protected areas

1.4. Identify at least 5 sites per protected area for review by iwi, land managers, and community groups detailing intentions for use, including alterations and request information about previous management/biodiversity studies/predator management

Update geodatabase with Receptor Site ID and Phase 1 information for each proposed site

2.1. Is the site easily accessible for transporting live animals and equipment?

2.2. Does the site provide lizard habitat for the target species?

2.3. Gather information regarding previous site management and future plans.

2.4. Assess the site to receive monitoring equipment and enhancement, confirm with land managers.

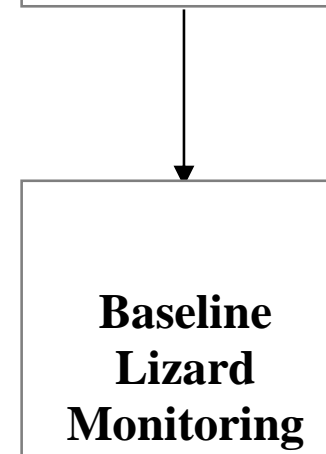

Update geodatabase with Phase 2 information and status for each proposed site

A. Wildlife Authority required to handle or disturb lizards and iwi must approve permanent identification methods

B. Targeted monitoring for species life history traits and habitat use (terrestrial, arboreal, diurnal, nocturnal, etc.)

C. Recommendations are for at least 250 trap nights per site to evaluate presence/absence

D. Monitoring equipment should be deployed early and remain deployed if the site is recommended for use from baseline monitoring results

Update geodatabase with monitoring results and status for each reviewed site and report findings to ARDS (a.k.a. the BioWeb Herpetofauna Database)

Phase 3:

Site

Preparation

3.1. Habitat enhancement should occur at site at least 3 months prior to use as a receptor site

3.2. Predator control should be partnered with routine monitoring and should be implemented 3-6 months prior to use as a receptor site

3.3. Fencing in preparation for translocated individuals (if applicable)

Update geodatabase with Phase 3 information and status for each reviewed site 


\subsubsection{Geodatabase improvements}

I used my experience at receptor sites to build characteristics into a geodatabase that are important for capturing all the information I was exposed to and that would later be a critical aspect of the record for a mitigation translocation. Maps in AcrGIS are used as the foundation for the geodatabase. These are initiated in phase 1 desktop site selection and updated during phase 2 site visits. They can show detail, such as, polygons representing sites, through to monitoring trap information or key features. Attribute tables are then associated with sites and display datafor the site based on "fields", columns of data (Supplementary Figure S3.1.). I propose geodatabase fields that expand on current translocation database information to include more receptor site information and cover the recommended selection criteria. The geodatabase should be all-inclusive, for used and unused sites at differing stages of preparedness and phases of mitigation translocations. I propose an attribute table (Figure 3.4.) to store responses /outcomes of the three phases and multiple criteria of site selection and preparation as sites are evaluated (Figure 3.5.).

Phase 1 includes fields which address criteria assessed in the desktop exercise: land tenure and boundaries, candidate species based on historical records, land cover classification (Land Resource Information System's (LRIS) land cover classification database v.4.1 (LCDBv.4.1)), and whether contact has been made with iwi, land managers, and community groups (sending preliminary proposals).

Criterion 1.1. Maps of regional and city council parks and reserves (available to the public online), with downloadable data for GIS use. Councils can also provide information regarding land parcels which they own or manage. At this stage, the main objective is to identify potential protected areas which are not likely to be subjected to future urbanization or major changes. 
Criterion 1.2. While many regional and city councils are investigating lizard taxa in their respective areas to meet biodiversity strategy standards, identifying and evaluating lizard populations at a large scale requires long-term intensive monitoring. Further complicating this issue, recent taxonomic studies have identified over 70 new lizard species, with many being data deficient with respect to distribution and threat status (Hitchmough et al., 2016). Understanding the lizard biodiversity in urban areas has been relatively understudied in recent years. Current resources for councils include using New Zealand field guides and publications on taxonomic research (Hitchmough et al., 2016; van Winkel et al., 2018) as well as recent lizard records available by contacting local herpetologists and community members familiar with the area and habitats suitable for local native species, using citizen science applications such as iNaturalist, the ARDS database (available from DOC), and the translocation database (also available by request from DOC).

Criterion 1.3. After potential target species are identified and confirmed to have estimated historical ranges which included proposed protected areas, knowledge of habitat use (from herpetofauna guides and experts) can inform receptor site identification within protected areas. The Land Resource Information System (LRIS) Portal offers multiple environmental datasets at the national and regional level, the most recommended for assessing available habitat is the Landcare database (LCDB) v.4.1. (Deprecated) land cover dataset (applied to theWellington region in Figure 3.4.) which can be downloaded and used in GIS systems or accessed online using the LRIS portal. Several classifications for land cover are listed,including identification of areas made of mostly gorse/broom and exotic grasses to forest typeclassifications. While a useful starting point, aerial imagery can take 3-5 years to be processed and made available online, making site visits essential to understand current land cover and use. 
Criterion 1.4. Proposals should be sent to iwi, land managers, and community groups early to keep parties informed and request permission to alter the land.

Phase 2 lists habitat score (assessed using Table 3.1.), history of management (agriculture, predator control, restoration projects), and previous lizard monitoring efforts or translocations.

Criterion 2.1. Sites should have easy access via walking trails or driving (within four-wheel drive capabilities) to safely relocate live animals, minimize risks to ecologists and researchers,and easily transport monitoring equipment. Other considerations should include keeping the site inconspicuous from members of the public or providing signage to deter human disturbance to the site. It is also important to make sites accessible for volunteers, funding members, and community members who may wish to engage with the work.

Criterion 2.2. Habitat evaluations are complex and extensive. It is important to note that the land cover and major habitat type are present for the candidate species (examples of major habitat type identification in Table 3.1.) but microhabitats also need to be addressed in habitatassessment and enhancement (logs, rock formations/ stacks/ piles, shrub and tussock planting, etc.; Table 3.1.).

Criterion 2.3. Preference may be given to sites with history of lizard monitoring, predator control, and habitat enhancements. Long-term data is the most reliable resource in understanding lizard populations at sites, and population response to changes in predator presence and/or habitat changes (Towns, 1995; Hoare et al., 2007; Reardon et al., 2012; Wilson et al., 2017; Herbert, 2020). Any previous translocations to the site should also be investigated as these translocated groups would require assessment prior to receiving more translocated individuals, particularly if they occupy the same habitat. 
Baseline monitoring occurs between Phases 2 and 3 and lists detailed methodology and results. Toe coding was not used in this study to permanently identify individuals but is a strong recommendation for future baseline monitoring surveys. Permanent identifiers (typically toe coding for skinks and photo ID for geckos) along with temporary identification methods (marking the body with a xylene-free marker) are essential to conduct individual analyses over multiple sessions and can provide information on individual habitat use and movement. The latter application is important in considering new research from Chapter 2 (indicating a 90- metre dispersal event of one northern grass skink) and dispersal observed in other herpetofauna translocation studies (Ebrahimi \& Bull, 2013; Nafus et al., 2017, Nash \& Griffiths, 2018).

Phase 3 and Translocation Data sections provide a record of site management following baseline monitoring and for detailed methodology of translocations and translocation monitoring results. Within these phases, I proposed fields for capturing the translocation information such as the number salvaged, dates of release, number released, and holding methods between salvage and release (such as captivity over winter, if applicable), methods and results of post-release monitoring, the number of individuals recaptured in post-release monitoring, effort around predator control and results, habitat enhancement, and potentially columns for any supplementation as some sites may conceivably attract multiple release events. The fields can be used to store multi-session information or new fields could be added to show additional rounds of monitoring or management; however, this should be decided by the organization managing the database and be consistently applied among translocations (see "Predator Control Cont." in Phase 3; Figure 3.4.).

\subsection{Discussion}

Mitigation translocations are known to have high failure rates and inconclusive results 
(Germano et al., 2015; Sullivan et al., 2015), and should be further investigated before their use is continued as a mitigation strategy for herpetofauna. If mitigation translocations must continue, it is critical that methodology and compliance are recorded and reviewed to improve outcomes. The framework and recommendations of this chapter aimed to provide a tool to store mitigation translocation results and the methodology and assessments used leading up to the use of a receptor site in translocation.

I have reviewed current selection criteria for receptor sites of lizards and developed additional criteria which address the history and future plans of a receptor site, along with its current status and characteristics. I have integrated these criteria into a geodatabase template (adapted from the BioWeb Herpetofauna and Translocation Databases, Figure 3.4.) to store information in phases, grouping criteria together to be completed in desktop exercises or site visits. These components are therefore recommended to be used in conjunction to pre-emptively select and begin enhancements to future receptor sites in the form of a management framework (Figure 3.5.). I outline a framework as a flowchart and checklist for assessing site selection criteria and recommend using the geodatabase between phases to store assessment outcomes.

The feedback loop in the final framework allows sites which are listed as "Accept with changes" to be reviewed for use as receptor sites following necessary improvements. It will likely be at the discretion of the funding parties and ecologists to assess what changes are feasible to make at a site that would change its status to "Accepted", but the intended use would be for minor changes such as providing micro-habitat or discontinuing disturbance at the site (grass mowing, use of insecticides, predator control, or public restriction from the site, etc.). As such, the timeline for use is context specific and based on the extent of prior knowledge of lizards at sites, plans for habitat 
enhancement, and timeframes for predator presence to be managed.

Rejected sites represent those which met Phase 1 criteria but are removed because they failed on an aspect of Phase 2 criteria. Rejection reasons could include removal at the request of iwi, community groups, or land managers, drastic land use changes not evident until the site was visited, poor habitat suitability (e.g. access to sunlight), high risk (e.g. of natural disasters),or were inaccessible. A record of rejected sites and reasons for rejection could potentially be used to contribute to or justify future management initiatives and provide a foundation for translocations of other species.

Although the framework including the geodatabase and site selection phases was built with the experience of the GWRC project in Wellington, it could be adapted to assist in planning mitigation translocations of other species or using sites which do not have the same land tenure as regional parks or reserves (for example, public access land which has been restored such as the "Queen's chain"; Land Act, 1892; Anderson, 1977). The framework also has the potential to function at a national scale to collate mitigation translocation data, assist local government and management agencies in preparing for mitigation translocation requests, and isolate problem areas in current mitigation translocation protocols so they may provide better outcomes for herpetofauna at a greater scale. 


\section{Chapter 4}

\section{Selection and preparation of mitigation translocation receptor sites}

\subsection{Introduction}

Mitigation translocations, the intentional relocation of wildlife to a new area to mitigate the effect of human activities on wildlife (Germano et al., 2015), have high failure rates and uncertain outcomes, leading many researchers and wildlife protection agencies to question their effectiveness at truly mitigating damages to lizards (Sullivan et al., 2015; Lennon, 2019). In the last 20 years, mitigation translocations have become one of the most frequently used types of translocations occurring annually in New Zealand, particularly for herpetofauna (Romijn \& Hartley, 2016). These translocations largely take place to 
mitigate damage of developments at a site which will have a negative impact on lizards and their habitat, in accordance with legislation such as the Wildlife Act (1953), Conservation Act (1987), and Resource Management Act (1991). Although mitigation translocations have been frequently used in the last 20 years to 'mitigate' harm to lizards due to development, they have been shown to often only meet legal obligations to relocate wildlife endangered by development to a new area (Lennon, 2019). This means they have historically not provided a net conservation benefit to the impacted species and long-term success post-release is understudied and underrepresented in literature (Miller et al., 2014; Ewen et al., 2014; Germano et al., 2015). Therefore, if the long-term success of a mitigation translocation cannot be confirmed, then an outcome benefiting biodiversity has not been achieved, and the choice of selecting translocation as a mitigation tool must be weighed against other tools available to developers, ecologists, and territorial authorities (Germano et al., 2015). These include environmental and biodiversity offsets (Brown et al., 2013; 2014), financial compensation to other conservation projects, or denying applications for development (Department of Conservation, 2018; 2019; Department of Conservation Lizard Technical Advisory Group, 2019).

As most mitigation translocations are considered to meet legal obligations when the salvage and relocation have occurred (or in some cases after some post-release monitoring occurs), they do not usually utilise "best-practice" protocols as outlined for translocations by the International Union for the Conservation of Nature (henceforth IUCN; IUCN/SSC, 2013) and Department of Conservation (henceforth DOC, (Department of Conservation Lizard Technical Advisory Group, 2018; 2019). For herpetofauna, best-practice protocols include assessment of lizard populations at the salvage and receptor sites prior to translocation, pre-emptive management of the receptor site to provide lizard habitat and control of introduced mammalian predators to protect 
lizards from predation, and long-term post-release monitoring of the translocated group, with results reported or published to appropriate agencies (e.g. DOC; IUCN/SSC, 2013; Department of Conservation Lizard Technical Advisory Group, 2018, 2019; Wildland Consultants, 2019c).

I gained experience in several aspects of mitigation translocations and investigated areas for improvement in current practices, both before the translocation takes place and after. I used short-term success criteria to evaluate a mitigation translocation and understand how improved protocols allow criteria to be applied and how to further adapt criteria for mitigation translocations. I contributed to the selection and preparation of receptor sites for mitigation translocations, aiming to improve current practices.

Specifically, my aims were:

1. Evaluation of survival and growth of translocated individuals in a mitigation translocation case study and whether resident populations at receptor sites effected these measurements;

2. Comparison of the mitigation translocation case study to other mitigation translocations and conservation translocations of herpetofauna to identify and address inconsistent practices between the translocation types which may influence outcomes;

3. Selection of potential receptor sites for northern grass skinks and completion of preliminary lizard surveys at these sites;

4. Preparation of recommendations for criteria for receptor sites selection and elements of a record-keeping geodatabase to list potential receptor sites to be used in conjunction with a receptor site management framework;

The case study evaluated is a cycleway development in Wellington, New Zealand which used translocation to mitigate negative impacts of development on the lizard population residing atthe site. Greater Wellington Regional Council is interested in studying 
proactive managementand preparation of receptor sites to receive lizards from mitigation translocations to improve mitigation translocation outcomes. Here, I review outputs of previous chapters and discuss them in the context of management recommendations for future mitigation translocations.

\subsection{Chapter overviews}

\subsubsection{Chapter two: Short-term success criteria for a mitigation translocation}

To address knowledge gaps in literature regarding recapture and growth of founders following a mitigation translocation, I conducted post-release monitoring for a mitigation translocation of northern grass skinks (Oligosoma polychroma) over two years. The translocation used two receptor sites to attempt to evaluate difference associated with and without resident populations (skink populations already residing at the site prior to translocation) - creating two translocated groups. I measured success using the first two short-term success stages described in Miller et al. (2014): survival and growth of founders, and evidence of reproduction. The recapture rate and body condition changes (calculated using snout-vent length and mass measurements) of each translocated group were compared to each other, resident groups (where possible), and northern grass skinks studied at non-translocated sites (control sites).

Recapture rates of translocated individuals were similar between receptor sites and were within the range of recapture rates at local control sites and other mitigation translocations of herpetofauna (Edgar et al., 2005; Nash et al., 2020; Trent Bell pers. comm.), but low in comparison to conservation translocations of herpetofauna in New Zealand (Nelson et al., 2002; van Winkel, 2008; van Winkel \& Habgood, 2009; Baling et al., 2013a). Body condition indices (BCI) declined immediately following translocation 
but increased beyond salvage BCI by the one-year post-release mark. There was no measurable difference in BCI of translocated individuals between receptor sites with or without a resident population.

This project was unable to thoroughly evaluate evidence of recruitment (Stage 2 short-term success, Miller et al., 2014) beyond the recapture of pregnant translocated females because of the possibility of unmarked residents at receptor sites. However, 50$60 \%$ of recaptured translocated females were observed to be pregnant at least once in post-release monitoring.

Dispersal was not studied in this project, but it is noteworthy that one lizard was observed to disperse 90 metres from its release point in early post-release monitoring, which in most instances would have been beyond the range of monitoring equipment. The mitigation translocation was found to be successful in its goal to relocate individuals from imminent danger and therefore meet legal obligations but has not yet shown results supporting short-term success at the receptor sites. Low numbers of translocated individuals were recaptured (11.1\%), indicating uncertain outcomes for the majority that were not recaptured following release and raising concern that net conservation loss is occurring as a result of mitigation translocation activity. However, for those recaptured, improved body condition and pregnancy in translocated females implies suitable habitat and resource availability at both receptor sites.

Uncertainty around outcomes of mitigation translocations means they may not meet expectations of national laws such as the Wildlife Act (1953) and Conservation Act (1987) (Miskelly, 2014; Lennon, 2019), and conflict with national and regional biodiversity initiatives to identify and preserve biodiversity in urban areas (Department of Conservation, 2020a; Greater Wellington Regional Council, 2016; Wellington City 
Council, 2015). I make recommendations in this chapter which re-iterate those made by previous translocation reviews (Dodd \& Seigel, 1991; Germano \& Bishop, 2009), particularly for mitigation translocations of herpetofauna (Edgar et al., 2005; Germano et al., 2015; Sullivan et al., 2015; Lennon, 2019). Primarily, it is necessary to thoroughly survey potential receptor sites to understand resident populations which may inhabit them (and further study how residents and translocated groups may interact; such as Mulder et al., 2017), to conduct multiple post-release monitoring sessions over multiple years to accurately evaluate the outcome of a translocation, and publish results and methodology to isolate problems. In the future, mitigation translocations should investigate dispersal of New Zealand lizards (even those which are not known to have a homing instinct) and employ genetic analysis to evaluate reproduction and the integration of translocated groups into resident populations. The lessons learned from this case study provided insight and improvements to the methodology developed for Chapter 3, an investigation into the selection and preparation of receptor sites.

\subsubsection{Chapter three: Receptor site preparedness for mitigation translocations of lizards}

Following a mitigation translocation of northern grass skinks to a regional park in the Wellington region which resulted in high mortality rates during captivity and low recapture rates post-release (Trent Bell and Richard Romijn pers. comm.), Greater Wellington Regional Council (GWRC) initiated a project to prepare for the use of regional parks as receptor sites in future mitigation translocation requests. I evaluated six sites in two regional parks and one recreation reserve (owned by DOC) as potential receptor sites for translocated lizards, using a combination of desktop exercises and fieldwork. I conducted baseline monitoring for analysis of resident populations. I used this experience to develop a framework for future mitigation translocations, including 
updated receptor site selection criteria to include information about the future management plans at the site, habitat assessment results, community involvement, and results from baseline surveys to assess resident populations.

The framework also recommends the use of a geodatabase to store receptor site information for all evaluated sites (potential, approved, or rejected) during different stages of evaluation (phases). This framework was developed to assist in record-keeping and encourage compliance surrounding the guidelines and key principles recommended for conservation translocations by the IUCN (IUCN/SSC; 2013) and DOC (Department of Conservation Technical Advisory Group; 2019) in the event of a mitigation translocation. Mitigation translocations should be re-evaluated as the go-to methodology for mitigating harm to lizards due to development; however, if they are the only option, use and publication of record-keeping such as this framework can help isolate and address issues with mitigation translocations.

\subsection{Testing the framework}

I conducted a retrospective review of the choice of receptor sites for the study in Chapter 2 to test site selection aspects of the framework. I focussed on land cover and habitat classifications, site protection status, previous or ongoing management of the sites, and previous lizard monitoring.

These sites were initially selected based on provision of northern grass skink habitat ascertained by reviewing aerial imagery (site B) or consulting previous monitoring results (site A), and the opportunity to study the presence of a resident population at a translocation receptor site. This was not intended to be a re-enforcement of the resident population, but rather to study the survival and growth of translocated individuals post- 
release alongside an established population utilizing the same resources and habitat (Wildland Constultants, Ltd., 2018).

Using my framework, receptor site A (Mount Victoria) is a good candidate to receive northerngrass skinks. Using the Land Resource Information System (LRIS) land cover classification database (LCDB v.4.1.), the site is classified as "Urban parkland/Open space" and on the eastern side of the site, "Exotic forest", and comprised of open-canopied grasses and revegetating native bush, providing habitat for sun basking and protection from the elements and predators. Considering land tenure, the site is managed by Wellington City Council, and protected from urbanization as a city park unless major changes (which require public consultation) are made to land classifications. Considering agents of decline, the site has early-stage predator control (trapping stations) which will increase as the next phases of predator eradication for the Predator Free Wellington project expand eastward from Miramar peninsula to include Mount Victoria (Greater Wellington Regional Council, 2019).

Evidence of lizards at a site can increase confidence that the site has appropriate habitat for lizards. Previous studies at this site did not detect the presence of skinks (Woolley, 2020), but trapping for that study was conducted in regenerating native bush/forest habitat so may have missed the primary habitat for grass skinks. Therefore, increasing confidence in habitat enhancement and predator control offset the evidence of skinks, and selection of this site was viewed as an opportunity to contribute to restoration of skinks. In retrospect, using my framework, the release points of some lizards were not ideal as the regenerating bush and forest would change the canopy cover and habitat covariates in the future. Furthermore, the first session of post-release monitoring did not target all release points, only those which were on the previously established grid in regenerating bush and forest. Installation of traps along the edge of bush/grass were more 
successful in catching lizards, reinforcing the species specific aspects emphasised in the framework.

Using my framework, receptor site B would not likely have been chosen based on the desktopexercise as it is listed as "Built-up Area (Settlement)" (LCDB v4.1.). However, a walk through demonstrates the habitat is similar in composition to the salvage site (and more similar than site A to the salvage site), including rocky ground cover, with grasses and small Coprosma spp. shrubbery, emphasising the need to include both approaches to site selection. Land tenure is secure with Wellington City Council and is often referred to as a part of the Queen's Drive Reserve, although the same caveat applies as site A with regard to changes in land classification depending on urban pressures. Resident lizards were observed at this site, but no baseline monitoring to understand the abundance, density and diversity was conducted. Residents were not individually identifiable in subsequent monitoring until toe coding began post-release. This site may not have been classified as "Approved" if baseline monitoring of residents had indicated a high resident population, for the benefit of both translocated and resident groups. One possible solution to a high catch at the site could have been to assess an adjacent site in the general area or to enhance the proposed site to support a larger lizard population, for example, habitat attributes and predator control.

Improvements are still needed to best understand the short-comings of mitigation translocations of herpetofauna, particularly improvements in the applied use of "bestpractice" methodology and compliance to legal obligations set out by DOC and territorial authorities. Future studies should prioritize using best practices and isolating each of the factors which mayaffect low recapture rates and success rates such as individual dispersal, habitat enhancement, presence of predators and resident population effects. It is my recommendation that these factors be further assessed before evaluating the use 
of receptor sites with resident populations to receive translocated individuals, although with the continued struggle over land use between wildlife and humans, this will require further study as well.

\subsubsection{What aspects of the framework need further testing and expansion?}

This thesis studied differences between receptor sites with and without resident individuals of the same species as the translocated species (O. polychroma). However, the proposed framework does not currently include criteria evaluating other species at receptor sites which may have interspecific interactions with the translocated species, particularly other lizard species which may have similar habitat and resource use. Historical data can inform preparation of receptor sites for species which are likely translocation candidates and monitoring can be expanded beyond detecting resident populations of the translocated species. In this case, different trapping tools would need to be deployed to capture geckos or arboreal species. The framework has also not been tested or considered with respect to use for other species. Although clearly many of the aspects apply, there may also be species specific requirements that need additional consideration, for example, species that have different habitat needs at different life stages (Nafus et al., 2017; Markle et al., 2018).

The framework holds recommendations for the selection and preparation of receptor sites but does not include recommendations regarding the different options for site size or translocation sizes which might trigger use of those sites. One solution could be the preparation of multiple sites with a range of sizes and assessment of carrying capacity and appropriate translocated group size for that. It is also important that translocation propagules have a balanced composition regarding sex (Male/Female) and life stage (Adult/Juvenile) to encourage population growth post-release (IUCN/SSC, 
2013; Department of Conservation Lizard Technical Advisory Group, 2018; 2019; Wildland Consultants, 2019c). The framework also does not currently elaborate on recommendations for long-term management concerns. Such considerations include genetic bottlenecking and population fragmentation. These might be a consideration where supplementation/reinforcement can be justified at a later date.

\subsubsection{How can this framework be applied more widely?}

The framework developed in Chapter 3 was produced primarily for use in GWRC's mitigation translocation research project, but could be applied to a larger scale, similar to the BioWeb Herpetofauna and Translocation Databases currently managed by DOC. This could include other species of lizards, and more generally to fauna affected by mitigation translocations. In some cases, work conducted for one species might be easily applied to another, meaning there is an excellent opportunity to leverage off earlier effort because it is all recorded in the database.

I focussed on sites with long-term land tenure and legal protection by local governing bodies, but there are opportunities to include any sites that could be habitat for the species of interest. For lizards this could be edge habitat such as the "Queen's chain", public-access land adjacent to rivers and coastal sites (Land Act, 1892; Anderson, 1977; Mason, 1991). Restoration sites adjacent to suburbia, for example, gullies are not likely to appear like good receptor sites using the land cover database (LCDB v.4.1) but may be excellent new opportunities arising from community groups and local governmental agency restoration efforts (Ingram, 2008; Klaus \& Kiehl, 2021). Further edge sites and reclaimed land could be particularly helpful receptor sites for mitigation translocations of native lizards, which salvage low numbers but are still be required to continue (Lennon, 2019). 
For the framework and criteria to be most effective, inconsistencies in legal obligations must be rectified and compliance to improved standards and requirements enforced (such as the implementation of habitat enhancement at an appropriate time in the translocation process and follow-up on continued compliance; Lennon, 2019). As protocols improve and legal obligations become more consistent, community groups could become more involved to enhance protected areas in their community with the purpose of receiving lizards displaced by development alongside regional and national entities (such as the goals of Whareroa Guardians with DOC and GWRC). The desire to reduce introduced predators (Reardon et al., 2012; Russell et al., 2015; Department of Conservation, 2020b; 2021) and restore native biodiversity by means of conservation translocations (Department of Conservation, 1999) is already present in community groups throughout the country and could provide opportunity to engage the public in conservation of native biodiversity, improve mitigation translocation practices, and see better outcomes from mitigation translocations of herpetofauna.

To conclude, this thesis reviewed and addressed some of the issues with mitigation translocations of herpetofauna, both globally and in New Zealand, particularly post-release monitoring and the selection of receptor sites. This thesis emphasizes two points: the importance of utilizing several, if not all, conservation translocation techniques recommended by the IUCN and DOC and the publication of methodology and results used in mitigation translocations. Using best practices and reporting protocols are essential to move forward in isolating problem areas of mitigation translocations, to improving long-term success, and re-evaluating their use for mitigation of human activities. To integrate these points into regular use in mitigation translocations, I developed a framework and geodatabase to provide structure and accountability in the selection and preparation of receptor sites. However, these outputs and recommendations 
are only a starting point and do not solve the many issues with mitigation translocations - they simply provide an experimental tool and still require testing and improvements for use in realistic situations. If the application of "best-practice" protocols does not improve the success rates of mitigation translocations, they must be re-assessed as the "solution" to mitigate harm to lizards due to development and other options for mitigation or offset of damage from development considered. If they must be used, it is necessary that they employ principles and guidelines established by international and national agencies for conservation translocations, which historically produce better outcomes for biodiversity, and not just employ methods to meet legal obligations. The recommendations made from the Chapter 2 case study and the framework/geodatabase produced in Chapter 3 incorporate conservation translocation strategies for herpetofauna that have been recommended for 30 years (Dodd \& Seigel, 1991; Germano \& Bishop, 2009). If mitigation translocations (particularly of herpetofauna) must continue, they should employ these recommendations and publish results to further the field and improve current practices before continuing as a reliable method for development mitigation 


\section{Bibliography}

Anderson, G. E. (1977). The Queen's Chain. The Landscape.

Anderson P, Bell T, Chapman S, Corbett K. (2012). New Zealand lizards conservation toolkit - a resource for conservation management of the lizards of New Zealand.

Society for Research on Amphibians and Reptiles of New Zealand (SRARNZ).

Angeli, N. F., Lundgren, I. F., Pollock, C. G., Hillis-Starr, Z. M., \& Fitzgerald, L. A. (2018).Dispersal and population state of an endangered island lizard following a conservation translocation. Ecological Applications, 28(2), 336-347. https://doi.org/https://doi.org/10.1002/eap.1650

Animal Welfare Act. (1992). Australia legislation.

Armstrong, D. P., \& Seddon, P. J. (2008). Directions in reintroduction biology. Trends in ecology \& evolution, 23(1), 20-25.

Auckland Council. (2012). Auckland Council's Indigenous Biodiversity Strategy.

Balestrieri, A., Remonti, L., \& Prigioni, C. (2006). Reintroduction of the Eurasian badger (Meles meles) in a protected area of northern Italy. Italian Journal of Zoology, 73(3), 227-235.

Barrientos, R., \& Megía-Palma, R. (2021). Associated costs of mitigationdriventranslocation in small lizards. Amphibia-Reptilia, 1-8. https://doi.org/https://doi.org/10.1163/15685381-bja10040

Barwick, R. E. (1959). The life history of the common New Zealand skink Leiolopisma zelandica (Gray, 1843). In Transactions of the Royal Society of New Zealand (Vol. 86, No. 3/4, pp. 331-380).

Batson, W. G., Gordon, I. J., Fletcher, D. B., \& Manning, A. D. (2015). REVIEW: Translocation tactics: a framework to support the IUCN Guidelines for wildlife translocations and improve the quality of applied methods. Journal of Applied Ecology,52(6), 1598-1607. https://doi.org/https://doi.org/10.1111/1365-2664.12498

Bongaarts, J. (2019). Summary for policymakers of the global assessment report on biodiversity and ecosystem services of the Intergovernmental Science-Policy Platform on Biodiversity and Ecosystem Services. Population and Development Review,45(3), 680-681. https://doi.org/https://doi.org/10.1111/padr.12283

Boretto, J. M., Cabezas, F., Kubisch, E. L., Sinervo, B., \& Ibarguengoytía, N. (2014). Changes in female reproduction and body condition in an endemic lizard, Phymaturus spectabilis, following the Puyehue volcanic ashfall event. Herpetological Conservation and Biology.

Bradley, H. S., Tomlinson, S., Craig, M. D., Cross, A. T., \& Bateman, P. W. (2020). Mitigation translocation as a management tool. Conservation Biology. https://doi.org/10.1111/cobi.13667

Broome, K., Brown, D., Brown, K., Murphy, E., Birmingham, C., Golding, C., Corson, P., Cox, A., \& Griffiths, R. (2017). House mice on islands: management and lessons from New Zealand. In C. R. Veitch, M. N. Clout, A. R. Martin, J. C. Russell, \& C. J. West (Eds.), Island invasives: scaling up to meet the challenge. Proceedings of the international conference on island invasives 2017. 
Brown, M. A. (2017). Last line of defence: a summary of an evaluation of environmental enforcement in New Zealand. Policy Quarterly, 13(2). https://doi.org/10.26686/pq.v13i2.4665

Brown, M. A., Clarkson, B. D., Barton, B. J., \& Joshi, C. (2013). Ecological compensation: an evaluation of regulatory compliance in New Zealand. Impact Assessment and Project Appraisal, 31(1), 34-44.

Brown, M. A., Clarkson, B. D., Stephens, R. T. T., \& Barton, B. J. (2014). Compensating for ecological harm - the state of play in New Zealand. New Zealand Journal of Ecology, 38(1), 139-146. http://www.jstor.org/stable/24060832

Brown, J. R., Bishop, C. A., \& Brooks, R. J. (2009). Effectiveness of short-distance translocation and its effects on western rattlesnakes. The Journal of Wildlife Management, 73(3), 419-425.

Burns, B., Innes, J., \& Day, T. (2012). The Use and Potential of Pest-Proof Fencing for Ecosystem Restoration and Fauna Conservation in New Zealand. In M. J. Somers \& M.Hayward (Eds.), Fencing for Conservation: Restriction of Evolutionary Potential or a Riposte to Threatening Processes? (pp. 65-90). Springer New York. https://doi.org/10.1007/978-1-4614-0902-1_5

Chapple, D. G. (2016). New Zealand Lizards. Springer. Switzerland.

Chapple, D. G., Hitchmough, R. (2016) Biogeography of New Zealand lizards. In New Zealand Lizards (pp. 109-131). Springer.

Conservation Act. (1987). New Zealand legislation.

Conservation of Habitats and Species Regulations. (2010). Legislation of the United Kingdom.

Cree, A., \& Hare, K. M. (2016). Reproduction and life history of New Zealand lizards. In New Zealand Lizards (pp. 169-206). Springer.

Cromarty, P. L., \& Alderson, S. L. (2013). Translocation statistics (2002 - 2010), and the revised Department of Conservation translocation process. Notornis, 60, 55-62.

Czech, B., Krausman, P. R., \& Devers, P. K. (2000). Economic Associations among Causesof Species Endangerment in the United States: Associations among causes of species endangerment in the United States reflect the integration of economic sectors, supporting the theory and evidence that economic growth proceeds at the competitive exclusion of nonhuman species in the aggregate. BioScience, 50(7), 593-601.

Daugherty, C. H., Patterson, G. B., \& Hitchmough, R. A. (1994). Taxonomic and conservation review of the New Zealand herpetofauna. New Zealand Journal of Zoology, 21(4). https://doi.org/10.1080/03014223.1994.9518002

Daugherty, C. H., Patterson, G. B., Thorn, C. J., \& French, D. C. (1990). Differentiation of the Members of the New Zealand Leiolopisma nigriplantare Species Complex (Lacertilia: Scincidae). Herpetological Monographs, 4. https://doi.org/10.2307/1466968

Daugherty, C. H., Patterson, G. B., \& Hitchmough, R. A. (1994). Taxonomic and conservation review of the New Zealand herpetofauna. New Zealand Journal of Zoology, 21(4). https://doi.org/10.1080/03014223.1994.9518002

Dayger, C. A., LeMaster, M. P., \& Lutterschmidt, D. I. (2018). Physiological correlates of reproductive decisions: Relationships among body condition, reproductive status, and the hypothalamus-pituitary-adrenal axis in a reptile. Hormones and Behavior, 100, 1 11.https://doi.org/https://doi.org/10.1016/j.yhbeh.2018.02.004 
Decker, D. J., \& Chase, L. C. (1997). Human dimensions of living with wildlife a management challenge for the 21 st century. Wildlife Society Bulletin , 788 795.

DeGregorio, B., Moody, R., \& Myers, H. (2020). Soft Release Translocation of Texas Horned Lizards (Phrynosoma cornutum) on an Urban Military Installation in Oklahoma,United States. Animals, 10(8). https://doi.org/10.3390/ani10081358

Department of Conservation. (1999). Translocation database summary.

Department of Conservation. (2019). Rare lizard habitat protected.

Department of Conservation. (2020a). Te Mana o te Taiao - Aotearoa New ZealandBiodiversity Strategy 2020.

Department of Conservation. (2020b). Towards a Predator Free New Zealand: PredatorFree 2050 Strategy.

Department of Conservation. (2021). Predator Free 2050: 5-year progress report.

Department of Conservation Lizard Technical Advisory Group. (2018). Guidelines for conservation-related translocations of New Zealand lizards.

Department of Conservation Lizard Technical Advisory Group. (2019). Key principles for lizard salvage and transfer in New Zealand.

Devan-Song, A., Martelli, P., Dudgeon, D., Crow, P., Ades, G., \& Karraker, N. E. (2016). Is long-distance translocation an effective mitigation tool for white-lipped pit vipers (Trimeresurus albolabris) in South China? Biological Conservation, 204, 212-220.

Dodd, C. \& Seigel, R. (1991). Relocation, repatriation, and translocation of amphibians and reptiles: Are they conservation strategies that work? Herpetologica, 47, 336350 .

Dudley, N., \& Stolton, S. (2008). Defining protected areas: an international conference in Almeria, Spain. IUCN, Gland.

Ebrahimi, M. \& Bull, C. (2012). Food supplementation reduces post-release dispersal duringsimulated translocation of the Endangered pygmy bluetongue lizard Tiliqua adelaidensis . Endangered Species Research, 18(2). https://doi.org/10.3354/esr00446

Ebrahimi, M. \& Bull, C. (2013). Determining the success of varying short-term confinement time during simulated translocations of the endangered pygmy bluetongue lizard (Tiliqua adelaidensis). Amphibia-Reptilia, 34(1), 31-39. https://doi.org/https://doi.org/10.1163/15685381-00002863

EcoGecko Consultants, Ltd. (2018). Queen Elizabeth Park and Whareroa Farm lizard surveys: Final report. Unpublished report for Kāpiti Coast Biodiversity Project, Wellington. 19p.

Edgar, P.W., Griffiths, R. A., \& Foster, J. P. (2005). Evaluation of translocation as a tool for mitigating development threats to great crested newts (Triturus cristatus) in England, 1990-2001. Biological Conservation, 122(1), 45-52.

Eifler, D. A., \& Eifler, M. A. (1999). The influence of prey distribution on the foraging strategy of the lizard Oligosoma grande (Reptilia: Scincidae). Behavioral Ecology and Sociobiology, 45(6), 397-402. https://doi.org/10.1007/s002650050576

Endangered Species Act of 1973 (ESA; 16 U.S.C. $§ 1531$ et seq.). Legislation of the United States of America. 
Ewen, John G, Soorae, P. S., \& Canessa, S. (2014). Reintroduction objectives, decisions and outcomes: global perspectives from the herpetofauna. Animal Conservation, 17, 74-81.

Fischer, J., \& Lindenmayer, D. B. (2000). An assessment of the published results of animal relocations. Biological Conservation, 96(1), 1-11.

Fitzgerald, L. A., Treglia, M. L., Angeli, N., Hibbitts, T. J., Leavitt, D. J., Subalusky, A. L.,Lundgren, I., \& Hillis-Starr, Z. (2015). Determinants of successful establishment and post-translocation dispersal of a new population of the critically endangered St. Croixground lizard (Ameiva polops). Restoration Ecology, 23(6), 776-786. https://doi.org/https://doi.org/10.1111/rec.12248

Flynn-Plummer, T. P., \& Monks, J. M. (2021). Penned release reduces area use by translocated barking geckos (Naultinus punctatus). New Zealand Journal of Ecology, 45(1).

Fritts, S. H., Bangs, E. E., Fontaine, J. A., Johnson, M. R., Phillips, M. K., Koch, E. D., \& Gunson, J. R. (1997). Planning and implementing a reintroduction of wolves to Yellowstone National Park and central Idaho. Restoration ecology, 5(1), 7-27.

Gallego-Carmona, C. A., Castro-Arango, J. A., \& Bernal-Bautista, M. H. (2016). Effect of Habitat Disturbance on the Body Condition Index of the Colombian Endemic Lizard Anolis antonii (Squamata: Dactyloidae). South American Journal of Herpetology, 11(3),183-187. https://doi.org/10.2994/SAJH-D-16-00020.1

Germano, J. M., \& Bishop, P. J. (2009). Suitability of Amphibians and Reptiles for Translocation. Conservation Biology, 23(1), 7-15. https://doi.org/https://doi.org/10.1111/j.1523-1739.2008.01123.x

Germano, J. M., Field, K. J., Griffiths, R. A., Clulow, S., Foster, J., Harding, G., \& Swaisgood, R. R. (2015). Mitigation-driven translocations: are we moving wildlife inthe right direction? Frontiers in Ecology and the Environment, 13(2), 100-105.

Gillies, C., \& Clout, M. (2003). The prey of domestic cats (Felis catus) in two suburbs of Auckland City, New Zealand. Journal of Zoology, 259(3), 309-315. https://doi.org/DOI:10.1017/S095283690200328X

Glen, A. S., Perry, M., Yockney, I., Cave, S., Gormley, A. M., Leckie, C., Dickson, R., Rakete-Stones, W., Rakete-Stones, P., Norbury, G. L., \& Ruscoe, W. A. (2019). a case study from Hawke's Bay, New Zealand. New Zealand Journal of Ecology, 43(1), 1-7.https://www.jstor.org/stable/26775030

Goldwater, N., Perry, G. L. W., \& Clout, M. N. (2012). Responses of house mice to the removal of mammalian predators and competitors. Austral Ecology, 37(8). https://doi.org/10.1111/j.1442-9993.2011.02356.x

Greater Wellington Regional Council. (2016). Greater Wellington Regional CouncilBiodiversity Strategy .

Greater Wellington Regional Council. (2019). Greater Wellington Regional PestManagement Plan 2019 - 2039.

Griffith, B., Scott, J. M., Carpenter, J. W., \& Reed, C. (1989). Translocation as a species conservation tool: status and strategy. Science, 245(4917), 477-480.

Grimm, N. B., Faeth, S. H., Golubiewski, N. E., Redman, C. L., Wu, J., Bai, X., \& Briggs, J. M. (2008). Global Change and the Ecology of Cities. Science, 319(5864).https://doi.org/10.1126/science.1150195

Hare, K. M. (2012). Herpetofauna: pitfall trapping. Department of Conservation Te 
PapaAtawhai V1, 1-22.

Hare K.M., Chapple D.G., Towns D.R., van Winkel D. (2016) The Ecology of New Zealand's Lizards. In New Zealand Lizards. Springer, Cham. https://doi.org/10.1007/978-3-319-41674-8_6

Harper, L. R., Downie, J. R., \& McNeill, D. C. (2019). Assessment of habitat and survey criteria for the great crested newt (Triturus cristatus) in Scotland: a case study on a translocated population. Hydrobiologia, 828(1), 57-71.

Hawke's Bay Regional Council. (2015). Hawke’s Bay Biodiversity Strategy 2015-2050.

Herbert, S. (2020). Is habitat enhancement a viable strategy for conserving New Zealand's endemic lizards? (Doctoral dissertation, Victoria University of Wellington, Wellington, New Zealand). Retrieved from https://researcharchive.vuw.ac.nz/

Hitchmough, R. A., Adams, L. K., Reardon, J. T., \& Monks, J. M. (2016). Current challenges and future directions in lizard conservation in New Zealand. Journal of the Royal Society of New Zealand, 46(1), 29-39.

Hitchmough, R. A., Barr, B., Lettink, M., Monks, J., Reardon, J., Tocher, M., van Winkel, D., \& Rolfe, J. (2016a). Conservation status of New Zealand reptiles, 2015. New Zealand Threat Classification Series.

Hoare, J M, Pledger, S., Keall, S. N., Nelson, N. J., Mitchell, N. J., \& Daugherty, C. H. (2006). Conservation implications of a long-term decline in body condition of the Brothers Island tuatara (Sphenodon guntheri). Animal Conservation, 9(4), 456462.https://doi.org/https://doi.org/10.1111/j.1469-1795.2006.00061.x

Hoare, Joanne M, Adams, L. K., Bull, L. S., \& Towns, D. R. (2007). Attempting to manage complex predator-prey interactions fails to avert imminent extinction of a threatened New Zealand skink population. The Journal of Wildlife Management, 71(5), 15761584.

Ingram, M. (2008). Urban Ecological Restoration. Ecological Restoration, 26(3), 175177.http://www.jstor.org/stable/43443122

Innes, J., Fitzgerald, N., Binny, R., Byrom, A., Pech, R., Watts, C., Gillies, C., Maitland, M.,Campbell-Hunt, C., \& Burns, B. (2019). New Zealand ecosanctuaries: types, attributes and outcomes. Journal of the Royal Society of New Zealand, 49(3), 370-393. https://doi.org/10.1080/03036758.2019.1620297

IUCN. (2012). Ecological restoration for protected areas: principles, guidelines and best practices.

IUCN. (2013). Guidelines for applying protected area management categories includingIUCN WCPA best practice guidance on recognising protected areas and assigning management categories and governance types.

IUCN/SSC. (2013). Guidelines for reintroductions and other conservation translcoations.

Jones, H. P., Holmes, N. D., Butchart, S. H. M., Tershy, B. R., Kappes, P. J., Corkery, I., Aguirre-Muñoz, A., Armstrong, D. P., Bonnaud, E., Burbidge, A. A., Campbell, K., Courchamp, F., Cowan, P. E., Cuthbert, R. J., Ebbert, S., Genovesi, P., Howald, G. R., Keitt, B. S., Kress, S. W., ... Croll, D. A. (2016). Invasive mammal eradication on islands results in substantial conservation gains. Proceedings of the National Academy of Sciences, 113(15). https://doi.org/10.1073/pnas.1521179113

Klaus, V. H., \& Kiehl, K. (2021). A conceptual framework for urban ecological restorationand rehabilitation. Basic and Applied Ecology, 52.

https://doi.org/10.1016/j.baae.2021.02.010 
Knox, C. D., \& Monks, J. M. (2014). Penning prior to release decreases posttranslocation dispersal of jewelled geckos. Animal Conservation, 17(S1), 18-26. https://doi.org/https://doi.org/10.1111/acv.12149

Kyek, M., Maletzky, A., \& Achleitner, S. (2007). Large scale translocation and habitat compensation of amphibian and reptile populations in the course of the redevelopmentof a waste disposal site. Zeitschrift Für Feldherpetologie, 14(2), 175190.

Le Coent, P., Préget, R., \& Thoyer, S. (2017). Compensating Environmental Losses Versus Creating Environmental Gains: Implications for Biodiversity Offsets. Ecological Economics, 142. https://doi.org/10.1016/j.ecolecon.2017.06.008

Le Gouar, P. , M. J. B. , S. F. (2012). Dispersal and habitat selection: behavioural and spatial constraints for animal translocations. In J.G. Ewen, D. P. Armstrong, K. A. Parker, \& P.J. Seddon (Eds.), Reintroduction Biology: Integrating Science and Management (pp.138-134). Wiley-Blackwell.

Lennon, O. (2019). Mitigation translocation for conservation of New Zealand skinks. (Doctoral dissertation, Victoria University of Wellington, Wellington, New Zealand). Retrieved from https://researcharchive.vuw.ac.nz/

Lettink, M., \& Hare, K. M. (2016). Chapter 10: Sampling Techniques for New Zealand Lizards . In D. G. Chapple (Ed.), New Zealand Lizards. Springer International Publishing. https://doi.org/10.1007/978-3-319-41674-8

Lettink, M., O’Donnell, C. F. J., \& Hoare, J. M. (2011). Accuracy and precision of skinkcounts from artificial retreats. New Zealand Journal of Ecology, 236-246.

Letty, J., Marchandeau, S., \& Aubineau, J. (2007). Problems encountered by individuals inanimal translocations: lessons from field studies. Ecoscience, 14(4), 420-431.

Linklater, W., \& Steer, J. (2018). Predator Free 2050: A flawed conservation policy displaces higher priorities and better, evidence-based alternatives. Conservation Letters, 11(6). https://doi.org/10.1111/conl.12593

Markle, C. E., Chow-Fraser, G., \& Chow-Fraser, P. (2018). Long-term habitat changes in a protected area: Implications for herpetofauna habitat management and restoration. PLOSONE, 13(2). https://doi.org/10.1371/journal.pone.0192134

Maron, M., Bull, J. W., Evans, M. C., \& Gordon, A. (2015). Locking in loss: Baselines of decline in Australian biodiversity offset policies. Biological Conservation, 192, 504-512. https://doi.org/https://doi.org/10.1016/j.biocon.2015.05.017

Maseyk, F., Ussher, G., Kessels, G., Christensen, M., \& Brown, M. (2018). Biodiversity Offsetting under the Resource Management Act: A guidance document. Prepared for the Biodiversity Working Group on behalf of the BioManagers Group.

Massei, G., Quy, R. J., Gurney, J., \& Cowan, D. P. (2010). Can translocations be used to mitigate human-wildlife conflicts? Wildlife Research, 37(5), 428-439.

Mason, Bruce. (1991). Public access along the Queen's Chain and Public Roads. In Public Access New Zealand.

McCoy, E. D., Osman, N., Hauch, B., Emerick, A., \& Mushinsky, H. R. (2014). Increasingthe chance of successful translocation of a threatened lizard. Animal Conservation, 17.https://doi.org/10.1111/acv.12145

McKinney, M. L. (2006). Urbanization as a major cause of biotic homogenization. BiologicalConservation, 127(3), 247-260. https://doi.org/https://doi.org/10.1016/j.biocon.2005.09.005 
Meserve, P. L., Kelt, D. A., Gutiérrez, J. R., Previtali, M. A., \& Milstead, W. B. (2016). Biotic interactions and community dynamics in the semiarid thorn scrub of Bosque fray Jorge National Park, north-central Chile: a paradigm revisited. Journal of Arid Environments, 126, 81-88.

Miller, K. A., Bell, T. P., \& Germano, J. M. (2014). Understanding Publication Bias in Reintroduction Biology by Assessing Translocations of New Zealand's Herpetofauna. Conservation Biology, 28(4), 1045-1056. https://doi.org/https://doi.org/10.1111/cobi.12254

Miskelly, C. M. (2014). Legal protection of New Zealand's indigenous terrestrial faunaan historical review. Tuhinga, 25, 25-101.

Monks, J. M., Monks, A., \& Towns, D. R. (2014). Correlated recovery of five lizard populations following eradication of invasive mammals. Biological Invasions, 16(1),167-175.

Monti, F., Dominici, J. M., Choquet, R., Duriez, O., Sammuri, G., \& Sforzi, A. (2014). The Osprey reintroduction in Central Italy: dispersal, survival and first breeding data. Bird Study, 61(4), 465-473.

Moore, J. A., Hoare, J. M., Daugherty, C. H., \& Nelson, N. J. (2007). Waiting reveals waning weight: Monitoring over 54 years shows a decline in body condition of a longlived reptile (tuatara, Sphenodon punctatus). Biological Conservation, 135(2), 181-188. https://doi.org/https://doi.org/10.1016/j.biocon.2006.10.029

Moreno-Mateos, D., Maris, V., Béchet, A., \& Curran, M. (2015). The true loss caused by biodiversity offsets. Biological Conservation, 192, 552-559.

https://doi.org/https://doi.org/10.1016/j.biocon.2015.08.016

Moseby, K. E., J. L. Read, D. C. Paton, P. Copley, B. M. Hill, and H. A. Crisp. 2011. Predation determines the outcome of 10 reintroduction attempts in arid South Australia. Biological Conservation 144:2863-2872.

Mulder, K. P., Walde, A. D., Boarman, W. I., Woodman, A. P., Latch, E. K., \& Fleischer, R. C. (2017). No paternal genetic integration in desert tortoises (Gopherus agassizii) following translocation into an existing population. Biological Conservation, 210, 318-324.

Nafus, M. G., Esque, T. C., Averill-Murray, R. C., Nussear, K. E., \& Swaisgood, R. R. (2017). Habitat drives dispersal and survival of translocated juvenile desert tortoises.Journal of Applied Ecology, 54(2), 430-438. https://doi.org/https://doi.org/10.1111/1365-2664.12774

Nash, D. J. (2017). An assessment of mitigation translocations for reptiles at development sites (Doctoral dissertation, University of Kent, University of Kent).

Nash, D. J., \& Griffiths, R. A. (2018). Ranging behaviour of adders (Vipera berus) translocated from a development site. Herpetological Journal, 28(4), 155-159.

Nash DJ, Humphries, N., \& Griffiths, R. (2020). Effectiveness of translocation in mitigatingreptile-development conflict in the UK. Conservation Evidence, 17, 7-11.

National Parks Act 1980. (1980). New Zealand legislation.

Nature Conservation Act 2014. Australia legislation.

Neilson, K., Curran, J. M., Towns, D. R., \& Jamieson, H. (2006). Habitat use by chevron skinks (Oligosoma homalonotum)(Sauria: Scincidae) on Great Barrier Island, New Zealand. New Zealand Journal of Ecology, 345-356. 
Nelson City Council. (2018). Nelson Biodiversity Strategy .

Nelson, N. J., Keall, S. N., Brown, D., \& Daugherty, C. H. (2002). Establishing a New Wild Population of Tuatara (Sphenodon guntheri). Conservation Biology, 16(4). https://doi.org/10.1046/j.1523-1739.2002.00381.x

Nelson, N. J., Romijn, R. L., Dumont, T., Reardon, J. T., Monks, J. M., Hitchmough, R. A.,Empson, R., \& Briskie, J. v. (2016). Lizard conservation in mainland sanctuaries. In New Zealand Lizards (pp. 321-339). Springer.

Newmark, W. D., Jenkins, C. N., Pimm, S. L., McNeally, P. B., \& Halley, J. M. (2017). Targeted habitat restoration can reduce extinction rates in fragmented forests.Proceedings of the National Academy of Sciences, 114(36). https://doi.org/10.1073/pnas.1705834114

Norbury, G., van den Munckhof, M., Neitzel, S., Hutcheon, A., Reardon, J., \& Ludwig, K. (2014). Impacts of invasive house mice on post-release survival of translocated lizards.New Zealand Journal of Ecology, 322-327.

Otago Regional Council. (2018). Our Living Treasure: Otago Regional Council'sBiodiversity Strategy 2018.

Owens, B. (2017). Behind New Zealand's wild plan to purge all pests. Nature, 541(7636).https://doi.org/10.1038/541148a

Parkes, J., Fisher, P., Robinson, S., \& Aguirre-Muñoz, A. (2014). Eradication of feral catsfrom large islands: an assessment of the effort required for success. New Zealand Journal of Ecology, 38(2), 307-314. http://www.jstor.org/stable/24060808

Pech, R., \& Maitland, M. (2016). Conservation of native fauna in highly invaded systems:managing mammalian predators in New Zealand. Restoration Ecology, 24(6). https://doi.org/10.1111/rec.12376

Peltzer, D. A., Bellingham, P. J., Dickie, I. A., Houliston, G., Hulme, P. E., Lyver, P. O., McGlone, M., Richardson, S. J., \& Wood, J. (2019). Scale and complexity implicationsof making New Zealand predator-free by 2050. Journal of the Royal Society of New Zealand, 49(3). https://doi.org/10.1080/03036758.2019.1653940

Pérez, I., Anadón, J. D., Díaz, M., Nicola, G. G., Tella, J. L., \& Giménez, A. (2012). What iswrong with current translocations? A review and a decision-making proposal. Frontiersin Ecology and the Environment, 10(9), 494-501.

Potere, D., \& Schneider, A. (2007). A critical look at representations of urban areas in globalmaps. GeoJournal, 69(1-2). https://doi.org/10.1007/s10708-007-9102-z

$\mathrm{R}$ Core Team. (2018). $R$ : A language and environment for statistical computing. $\mathrm{R}$ Foundation for Statistical Computing.

Reardon, J. T., Whitmore, N., Holmes, K. M., Judd, L. M., Hutcheon, A. D., Norbury, G., \& Mackenzie, D. I. (2012). Predator control allows critically endangered lizards to recoveron mainland New Zealand. New Zealand Journal of Ecology, 141-150.

Resource Management Act. (1991). New Zealand legislation.

Romijn, R. L., \& Hartley, S. (2016). Trends in lizard translocations in New Zealand between1988 and 2013. New Zealand Journal of Zoology, 43(2), 191-210. https://doi.org/10.1080/03014223.2016.1146311

Roser, M., Ritchie, H., \& Ortiz-Ospina, E. (2013). World Population Growth . Our World in Data. 
Rouco, C., de Torre-Ceijas, R., Martín-Collado, D., \& Byrom, A. E. (2017). New ZealandShouldn't Ignore Feral Cats. BioScience, 67(8). https://doi.org/10.1093/biosci/bix068

Russell, J. C., Innes, J. G., Brown, P. H., \& Byrom, A. E. (2015). Predator-Free New Zealand: Conservation Country. BioScience, 65(5). https://doi.org/10.1093/biosci/biv012

Salo, P., Korpimäki, E., Banks, P. B., Nordström, M., \& Dickman, C. R. (2007). Alien predators are more dangerous than native predators to prey populations. Proceedings of the Royal Society B: Biological Sciences, 274(1615), 1237-1243.

Schoukens, H. (2017). Reconciliation ecology in practice: Legal and policy considerations when implementing temporary nature on undeveloped lands in the European Union. Land Use Policy, 67, 178-189.

Seddon, P. J., Armstrong, D. P., \& Maloney, R. F. (2007). Developing the Science of Reintroduction Biology. Conservation Biology, 21(2). https://doi.org/10.1111/j.1523-1739.2006.00627.x

Seigel, R. A., \& Dodd, C. K. (2002). Translocations of amphibians: proven management method or experimental technique? Conservation biology, 16(2), 552-554.

Sherley, G. H., Stringer, I. A. N., \& Parrish, G. R. (2010). Summary of native bat, reptile, amphibian and terrestrial invertebrate translocations in New Zealand. (Issue 303). Department of Conservation.

Singers, N. J., \& Rogers, G. M. (2014). A classification of New Zealand's terrestrial ecosystems.

Spencer, N. J., Thomas, B. W., Mason, R. F., \& Dugdale, J. S. (1998). Diet and life history variation in the sympatric lizards Oligosoma nigriplantare polychroma and Oligosoma lineoocellatum. New Zealand Journal of Zoology, 25(4), 457-463. https://doi.org/10.1080/03014223.1998.9518169

Spencer, R. D., Beausoleil, R. A., \& Martorello, D. A. (2007). How agencies respond to human-black bear conflicts: a survey of wildlife agencies in North America. Ursus, 18(2), 217-229.

Spitzen - van der Sluijs, A., Spitzen, J., Houston, D., \& Stumpel, A. H. P. (2009). Skink predation by hedgehogs at Macraes Flat, Otago, New Zealand. New Zealand Journal ofEcology, 33(2), 205-207. http://www.jstor.org/stable/24060622

Sullivan, B. K., Nowak, E. M., \& Kwiatkowski, M. A. (2015). Problems with mitigation translocation of herpetofauna. Conservation Biology, 29(1), 12-18. https://doi.org/https://doi.org/10.1111/cobi.12336

Taranaki Regional Council. (2012). Taranaki Biodiversity Forum Accord 2012.

Taranaki Regional Council. (2017). Biodiversity Strategy 2017.

Teixeira, C. P., de Azevedo, C. S., Mendl, M., Cipreste, C. F., \& Young, R. J. (2007). Revisiting translocation and reintroduction programmes: the importance of consideringstress. Animal Behaviour, 73(1), 1-13.

https://doi.org/https://doi.org/10.1016/j.anbehav.2006.06.002

Towns, D. R. (1991). Response of lizard assemblages in the Mercury Islands, New Zealand,to removal of an introduced rodent: the kiore (Rattus exulans). Journal of the Royal Society of New Zealand, 21(2). 
https://doi.org/10.1080/03036758.1991.10431400

Towns, D. R. (1995). Changes in habitat use by lizards on a New Zealand island following removal of the introduced Pacific Rat Rattus exulans. Pacific Conservation Biology, 2(3). https://doi.org/10.1071/PC960286

Towns, D. R., \& Daugherty, C. H. (1994). Patterns of range contractions and extinctions in the New Zealand herpetofauna following human colonisation. New Zealand Journal ofZoology, 21(4). https://doi.org/10.1080/03014223.1994.9518003

Towns, D. R., Hitchmough, R. A., \& Perrott, J. (2016). Conservation of New Zealand Lizards: A Fauna Not Forgotten but Undervalued? In New Zealand lizards (pp. 293-320). Springer.

Tuberville, T. D., Clark, E. E., Buhlmann, K. A., \& Gibbons, J. W. (2005). Translocation as aconservation tool: site fidelity and movement of repatriated gopher tortoises (Gopherus polyphemus). Animal Conservation, 8(4), 349-358. https://doi.org/DOI: 10.1017/S1367943005002398

van Winkel, D. (2008). Efficiency of techniques for post-translocation monitoring of the Duvaucel's gecko (Hoplodactylus duvaucelii) and evidence of native avian predation on lizards: a thesis submitted in partial fulfillment of the requirements for the degree of Master of Science in Conservation Biology, Massey University, Auckland, New Zealand (Doctoral dissertation, Massey University).

van Winkel, D., Habgood, M.J. (2009) Tuatara survey on Tiritiri Matangi Island: Five years post-translocation. Unpublished report to the Department of Conservation, Auckland. 29p.

van Winkel, D., Baling, M., \& Hitchmough, R. (2018). Reptiles and Amphibians of NewZealand: A Field Guide.

Wedding, C. J. (2007). Aspects of the impacts of mouse (Mus musculus) control on skinks in Auckland, New Zealand: a thesis presented in partial fulfillment of the requirements for the degree of Master of Science in Conservation Biology at Massey University (Doctoral dissertation, Massey University).

Wellington City Council. (2015). Our Natural Capital: Wellington's biodiversity strategyand action plan 2015.

Whitaker, A. H. (1973). Lizard populations on islands with and without Polynesian rats, rattus exulans (peale). Proceedings (New Zealand Ecological Society), 20, 121-130. http://www.jstor.org/stable/24061519

Whitlow, W. L., Rice, N. A., \& Sweeney, C. (2003). Native species vulnerability to introduced predators: testing an inducible defense and a refuge from predation. In Marine Bioinvasions: Patterns, Processes and Perspectives. Springer Netherlands.https://doi.org/10.1007/978-94-010-0169-4_3

Wildland Consultants, Ltd. (2018). R4770: Lizard Management Plan for the Evans Bay andCobham Drive cycle routes, Wellington City. Unpublished report for Wellington City Council.

Wildland Consultants, Ltd. (2019a). R4770a: Lizard salvage on Tahitai, the Evans BayParade to Miramar Avenue cycle route, Wellington city. Unpublished report for Wellington City Council.

Wildland Consultants, Ltd. (2019b). R4770b: Baseline monitoring of northern grass skinks released at View Road South, Headland Reserve, Wellington. Unpublished report for Wellington City Council. 
Wildland Consultants, Ltd. (2019c). Guidance on methods to improve lizard protection and management during land use and development in the Wellington Region. Unpublished report for Greater Wellington Regional Council.

Wildlife Act. (1953). New Zealand legislation.

Wildlife \& Countryside Act. (1981). Legislation of the United Kingdom.

Wilmshurst, J. M., Anderson, A. J., Higham, T. F. G., \& Worthy, T. H. (2008). Dating the late prehistoric dispersal of Polynesians to New Zealand using the commensal Pacific rat. Proceedings of the National Academy of Sciences, 105(22). https://doi.org/10.1073/pnas.0801507105

Wilson, D. J., Innes, J. G., Fitzgerald, N. B., Bartlam, S., Watts, C., \& Smale, M. C. (2018). Population dynamics of house mice without mammalian predators and competitors. New Zealand Journal of Ecology, 42(2), 192-203. https://www.jstor.org/stable/26538110

Wilson, D. J., Mulvey, R. L., Clarke, D. A., \& Reardon, J. T. (2017). Assessing and comparing population densities and indices of skinks under three predator managementregimes. New Zealand Journal of Ecology, 41(1), 84-97. http://www.jstor.org/stable/26198786

Woolley, C. K. (2020). Conservation of endemic lizards in New Zealand cities. (Doctoral dissertation, Victoria University of Wellington, Wellington, New Zealand). Retrieved from https://researcharchive.vuw.ac.nz/

Woolley, C. K., Hartley, S., Hitchmough, R. A., Innes, J. G., van Heezik, Y., Wilson, D. J., \& Nelson, N. J. (2019). Reviewing the past, present and potential lizard faunas of New Zealand cities. Landscape and Urban Planning, 192, 103647. https://doi.org/https://doi.org/10.1016/j.landurbplan.2019.103647

Woolley, C. K., Knox, C., \& Watson, M. (2021). Evaluating the risk of predation for lizards constrained in live traps. New Zealand Journal of Zoology. https://doi.org/10.1080/03014223.2021.1918730 
Table S2.1.: Site names as referred to in this chapter, with common names and coordinates to accompany a map of site locations. Control site 6 was removed from this study after session 6 and continues to experience frequent land ownership changes.

\begin{tabular}{|c|c|c|}
\hline Site Reference Name & Site Common Name & (X-, Y- Coord.) \\
\hline Salvage Site & Cobham Drive & $41^{\circ} 18^{\prime} 59.8^{\prime \prime S} \quad 174^{\circ} 48^{\prime} 25.7^{\prime \prime} \mathrm{E}$ \\
\hline Receptor Site A & Mount Victoria & $41^{\circ} 18^{\prime} 03.4^{\prime \prime S} \quad 174^{\circ} 47^{\prime} 22.9^{\prime \prime} \mathrm{E}$ \\
\hline Receptor Site B & Houghton Bay & $41^{\circ} 20^{\prime} 40.3^{\prime \prime S} \quad 174^{\circ} 47^{\prime} 31.4^{\prime \prime E}$ \\
\hline Control Site 1 & Scorching Bay & $41^{\circ} 17^{\prime} 45.9^{\prime \prime S} \quad 174^{\circ} 49^{\prime} 57.5^{\prime \prime E}$ \\
\hline Control Site 2 & Ōtari-Wilton's Bush & $41^{\circ} 16^{\prime} 03.7^{\prime \prime S} \quad 174^{\circ} 45^{\prime} 29.9^{\prime \prime E}$ \\
\hline Control Site 3 & Karori Cemetery & $174^{\circ} 44^{\prime} 53.1^{\prime \prime} \mathrm{E}$ \\
\hline Control Site 4 & Wright's Hill & $41^{\circ} 17^{\prime} 44.3^{\prime \prime S}$ \\
\hline Control Site 5 & Te Ahumairangi Hill & $174^{\circ} 45^{\prime} 55.3^{\prime \prime} \mathrm{E}$ \\
\hline Control Site 6 & Massey Memorial & $41^{\circ} 17^{\prime} 13.6^{\prime \prime S} \quad 174^{\circ} 49^{\prime} 35.8^{\prime \prime E}$ \\
\hline
\end{tabular}




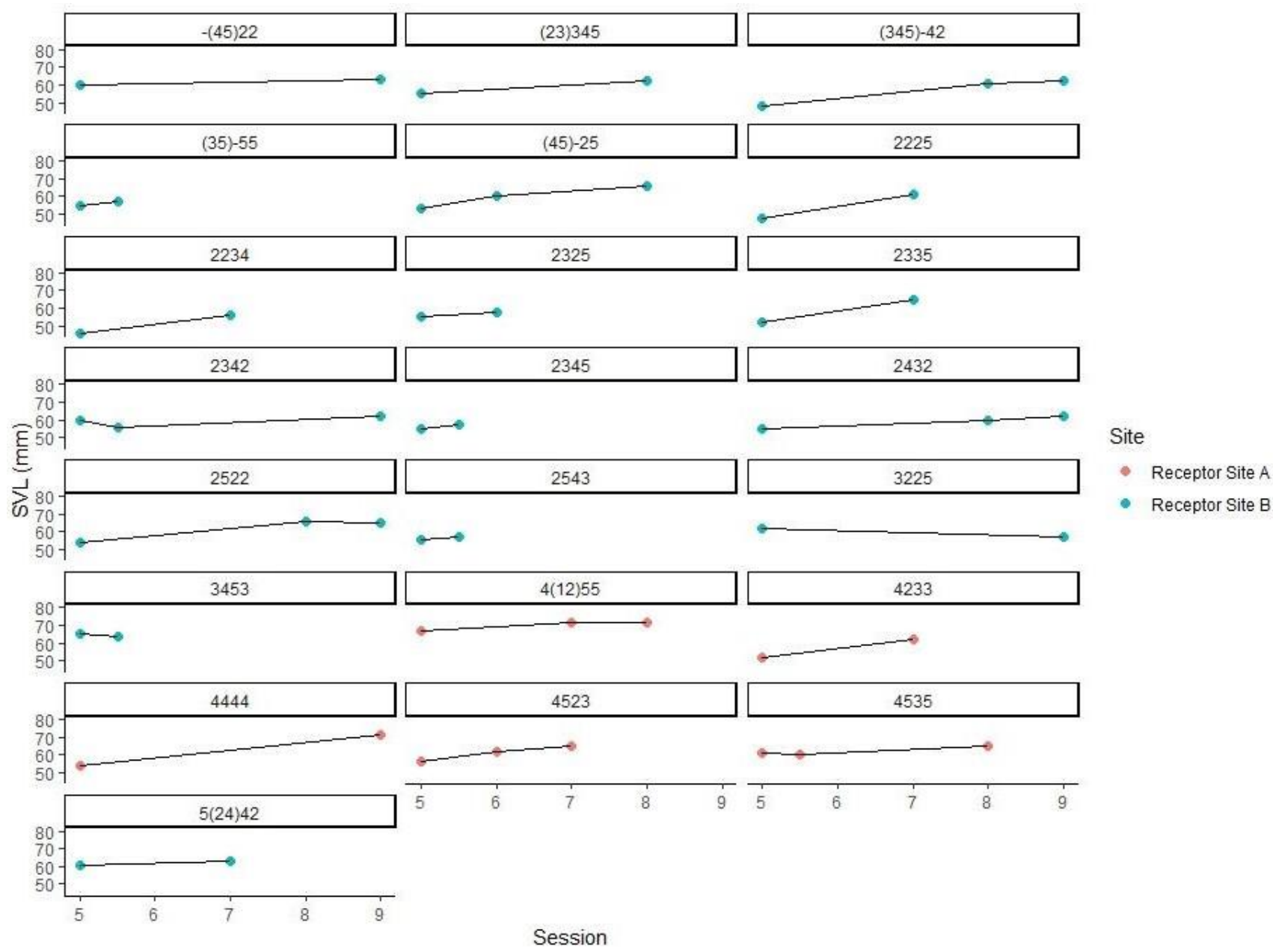

Figure S2.1.: Change in individual snout-vent length by session (time) for all individuals which could reliably be identified using permanent identifiers. Control sites are only reported for sessions $1-4$ unless an identifiable individual was recaptured following session 4. Some individuals captured at the salvage event (session 5) were previously captured in Pre-translocation monitoring. 


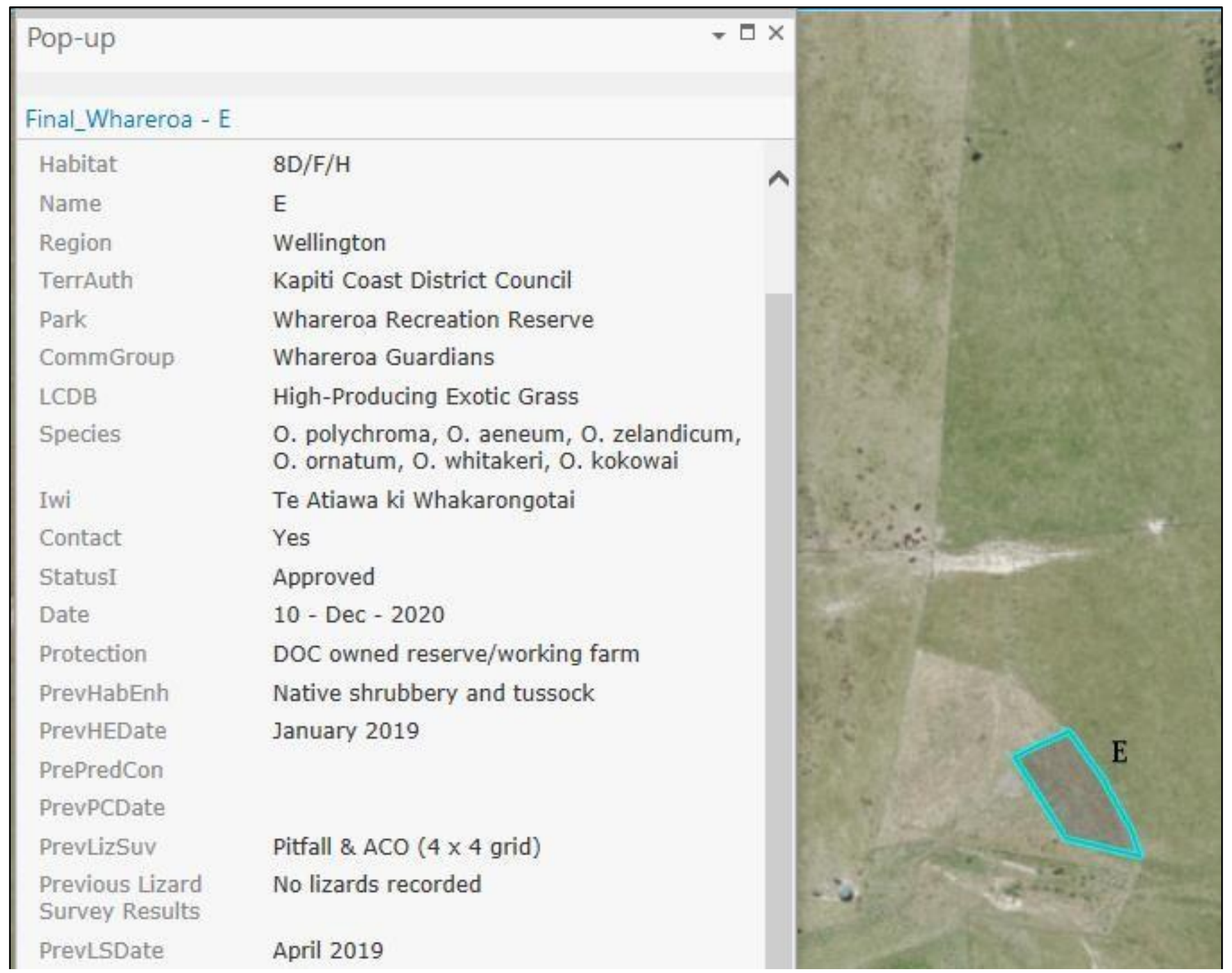

Figure S3.1.: A pop-up window in ArcGIS Pro v.2.4.0 providing attribute table fields (left) and site information (right) entered to the table for site $\mathrm{E}$ at Whareroa Farm. Once entered into the attribute, this information is attainable by using the "Identify" function on the site E polygon. 
